\title{
CACAO AGROFORESTRY UNDER AMBIENT AND REDUCED THROUGHFALL: TREE WA- TER USE CHARACTERISTICS AND STAND WATER BUDGETING
}

Dissertation

zur Erlangung des akademischen Grades Doctor of Philosophy (PhD) der Fakultät für Forstwissenschaften und Waldökologie der Georg-August-Universität Göttingen

vorgelegt von

Michael Köhler

geboren in Schmölln

Göttingen, 2010 
1. Gutachter: Prof. Dr. Dirk Hölscher

2. Gutachter: Prof. Dr. Edzo Veldkamp

Tag der mündlichen Prüfung: $\quad$ 05.05.2010

(Datum) 


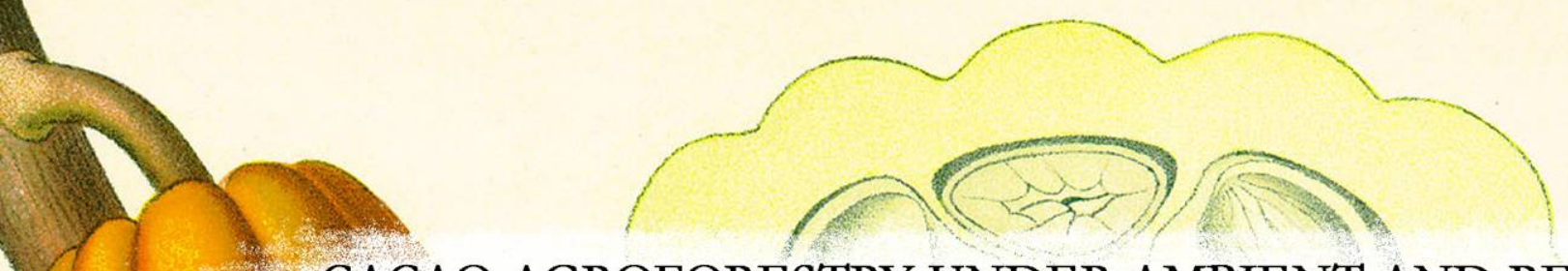

7 CACAO AGROFORESTRY UNDER AMBIENT AND REDUCED

- THROUGHFALL: TREE WATER USE CHARACTERISTICS AND STAND WATER BUDGETING
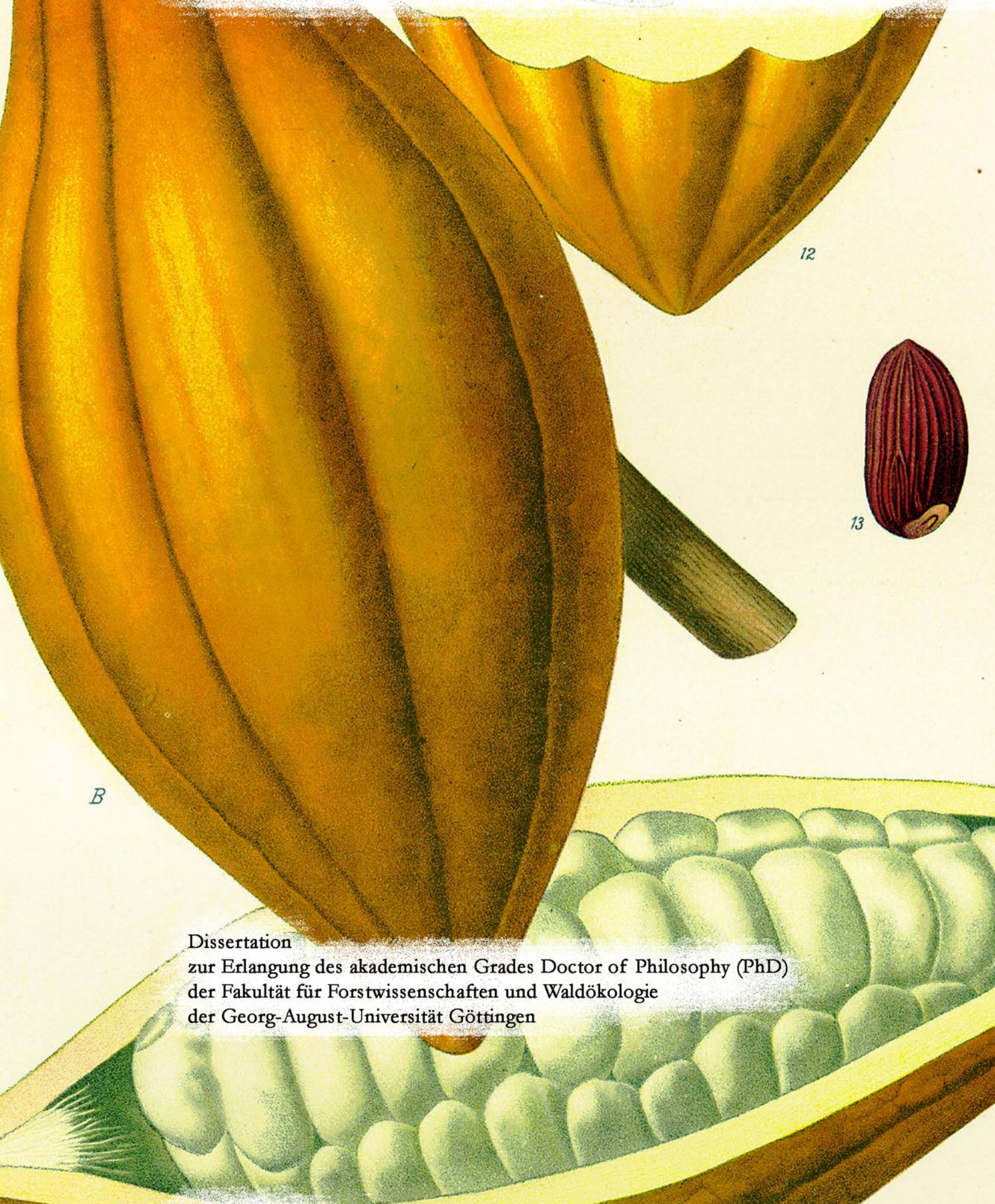

zur Erlangung des akademischen Grades Doctor of Philosophy (PhD) der Fakultät für Forstwissenschaften und Waldökologie

der Georg-August-Universität Göttingen

vorgelegt von

Michael Köhler

geboren in Schmölln

11 Göttingen, 2010
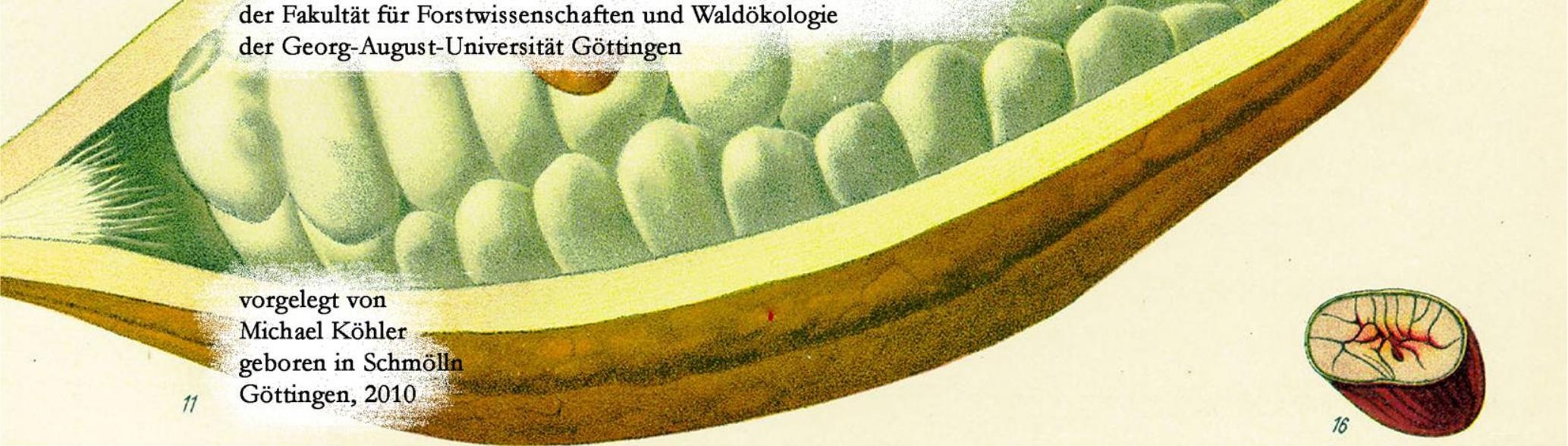

Theobroma Cacao L. 


\section{TABLE OF CONTENT}

Summary I I

$\begin{array}{ll}\text { Zusammenfassung } & \text { V }\end{array}$

\begin{tabular}{ll}
\hline Overview publications & XI \\
\hline
\end{tabular}

$1 \quad$ Introduction 1

$2 \quad$ Methodology 11

$\begin{array}{ll}2.1 \text { Overvien } & 13\end{array}$

$\begin{array}{ll}2.2 \text { Study sites and species selection } & 14\end{array}$

\begin{tabular}{|l|l|}
2.3 Experimental design of throughfall reduction & 17
\end{tabular}

2.4 Field set up and instrumentation 19

2.4.1 Micrometeorological measurements 19

2.4.2 Sap flux, tree water use, tree- and stand transpiration 20

2.4.3 Soil water content 24

2.5 Sap flux density mode 26

\begin{tabular}{|ll}
2.6 Soil water transport mode & 27
\end{tabular}

\begin{tabular}{|l|l}
2.6 .1 Theor & 27 \\
\hline 2.6 .2 Thodel & 27
\end{tabular}

\begin{tabular}{|l}
2.6 .1 \\
2.6 .2 Model parameterization
\end{tabular}

2.6 .3 Adjustment of soil bydraulic parameter.

$3 \quad$ Water use characteristics of cacao and Gliricidia trees 35 in an agroforest in Central Sulawesi, Indonesia

$4 \quad$ Comparison of tree water use characteristics in 57 reforestation and agroforestry stands across the tropics

$5 \quad$ Throughfall reduction in a cacao agroforest: $\quad 73$ tree water use and soil water budgeting

$\begin{array}{lll}6 & 103\end{array}$

\begin{tabular}{ll}
\hline Acknowledgments & 109
\end{tabular}

Supporting documents 111 



\section{CACAO AGROFORESTRY UNDER AMBIENT AND REDUCED THROUGHFALL: TREE WATER USE CHARACTERISTICS AND STAND WATER BUDG- ETING}

The world's tropical regions have faced dramatic losses in forest cover during recent decades. Although high rates of rainforest conversion continue today, reforestation is becoming more common. A variety of reforestation types exists, including reforestations with native trees, mixed reforestations with exotic trees, commercial monocultures or agroforests, which are combinations of trees and shrubs with crops and/or livestock. The reasons for reforestation are manifold: tree plantations and agroforestry provide means of income for farmers and thus ensure food security for the local population. Reforestation can also restore degraded land. Reforested areas often function as connectors between protected areas and areas under human occupation, and they have the capacity to capture and store carbon dioxide, helping mitigate climate change. Additionally, reforestation can aid in controlling erosion, help protect soil and water resources and may also facilitate the conservation of biodiversity.

However, reforestations are under critical debate because they may decrease stream water flow and groundwater recharge if their level of evapotranspiration is higher than that of previous vegetation. This could be especially problematic in areas where water resources are already under pressure due to water use for irrigation or other human needs. It is also important to note that evidence indicates global warming may lead to increasing frequency and severity of droughts in the (sub-) tropics, further aggravating problems of water scarcity. Therefore, species selection in terms of water use, competitiveness and drought resistance might be of great importance in the future management of agroforests or tree plantations. Unfortunately, few studies have been conducted on single tree water use rates of tropical species, even if such trees are commonly used in reforestations. In addition, limited information has been gathered on the capacity of tropical species or ecosystems to cope with abnormal water scarcity. Even more problematic, recent studies in old growth forests showed that species-independent relationships exist between water use and tree size, which would leave little space for species selection as a management option. Little is known about the environmental and arboreal structural components that drive water use patterns in tropical trees used for reforestations or agroforests.

In this dissertation these fields of study were addressed by conducting a large scale field experiment in a cacao/Gliricidia agroforest in Central Sulawesi. To begin this experiment, sap flux 
characteristics and tree water use were studied under ambient conditions and compared to other stands across the tropics in a second step. Further, a replicated throughfall reduction experiment was conducted within this agroforest thereafter, where net precipitation was reduced by $71 \%$ of the control for 13 months. After beginning the throughfall reduction experiment, sap flux response to declining soil moisture was described, and the soil water budget of the throughfall reduction scenario was compared to a control.

The main questions I addressed in this dissertation were:

1) How are tree sap flux and water use of trees in agroforests and reforestations controlled by species identity, tree structural components, environmental conditions and shade effects?

2) Do universal rules relating tree size to water use in old-growth forests also apply to reforestation and agroforestry stands in the tropics?

3) How are tree sap flux, water use, and the stand water budget of an agroforest influenced by artificially reduced canopy throughfall?

This research was conducted in the framework of the 'Stability of Rainforest Margins in Indonesia' (STORMA) project but is also based in part on data provided by other members of the 'Tropical Silviculture and Forest Ecology' working group (respective contributions are indicated in the Chapter "Overview Publications"). The dissertation compiles three publications (Chapters 3-5): The first addresses the environmental and arboreal structural components driving sap flux characteristics and tree water use of the cacao/Gliricidia agroforest in Central Sulawesi, Indonesia under ambient soil moisture conditions. Granier heat dissipation sap flux gauges were employed to measure sap flux densities in up to 18 individuals per species. Tree sap flux response to global radiation and vapor pressure deficit were measured and described using a Jarvis-Type sap flux model. The resulting model parameters and cumulative sap flux densities were then analyzed in relation to species identity and tree structure.

A second publication evolved from the compilation of the modeling results from the Indonesian agroforest with results from a separate study done on mixed reforestation stands in the Philippines and another done on mono-specific reforestation stands in Panama, resulting in a cross continental comparison of sap flux characteristics of more than 100 individual trees belonging to 17 species of similar size, age and management regimes. The aim here was to test for universal relationships between tree structure and water use within similar tropical land use systems and to see if different species would exhibit detectable differences in water use and sap flux response to environmental parameters. 
After the sap flux of cacao and Gliricidia trees in the Indonesian agroforest was assessed under ambient soil water conditions, the stand was subdivided into six plots, three of which ("roof plots') were covered with a sub-canopy roof made of bamboo frames and clear PVC foil to artificially reduce net precipitation. The third study discusses the effects of reduced throughfall on tree sap flux of both tree species. Data on stand transpiration, incoming throughfall, and measured soil water content are further brought together to parameterize a one dimensional soil water model, which describes the effects of reduced throughfall on the soil water budget in both the ambient and the reduced throughfall scenarios.

The main results of the study were the following:

1) The application of a Jarvis-type model to sap flux data from 18 trees per species in the cacao/Gliricidia agroforest showed that water use characteristics differed substantially between species despite comparable cumulated daily sap flux densities. Model parameters suggested a $49 \%$ higher maximum sap flux density of cacao as compared to Gliricidia. Differences in the response to environmental variables were also observed and are probably related to the greater exposure of Gliricidia trees. We found linearly increasing water use rates with increasing tree diameter in both species. However, due to a much shallower sap wood depth at a given diameter of Gliricidia trees, the rate of increase in water use with increasing tree diameter was lower in Gliricidia than in cacao. The average stand transpiration amounted to $1.5 \mathrm{~mm} \mathrm{~d}^{-1}$, and $70 \%$ of this total was attributed to cacao. Against expectations, increasing shade intensity led to increased water use rates in cacao trees, an effect probably linked to enhanced vegetative growth under shade. This suggests that in addition to exhibiting elevated stand transpiration due to the quantities of water used by shade trees, the transpiration of shaded cacao stands may also be increased by the impact of shade on the transpiration of cacao trees themselves.

2) When the same sap flux model was applied to sap flux data from more than 100 trees of 17 species from three study areas - Panamanian mono-specific reforestations, the Indonesian agroforest and Philippine mixed reforestations - up to threefold differences were detected in the maximum sap flux densities of different species. Significant differences were also found between different species within the same respective stands. The declining, species-independent relationship between sap flux density and tree diameter suggested in the literature could not be confirmed by this dataset. Nonetheless, a strong linear relationship was found between water use rates and tree diameter $\left(\mathrm{R}_{\text {adj }}^{2}=0.65\right)$. However, water use rates of different species at a given tree diameter differed up to twofold, and some species clearly followed distinct trajectories. 
3) In the cacao/Gliricidia agroforest different responses to declining soil moisture were found in both of the species studied. In the roof plots Gliricidia sap flux density already declined at higher soil water contents than cacao, and Gliricidia showed lower sap flux in the roof plots than in the control at all levels of vapor pressure deficit (VPD). In contrast, cacao sap flux remained similar to the control at low levels of VPD when atmospheric demand was low and was reduced only when evaporative demand was high. In the roof plots, the average monthly sap flux densities of both species decreased linearly with decreasing soil water content, reaching maximum reductions of $21 \%$ (cacao) and 29\% (Gliricidia) as compared to the control. A few possible explanations for the differing sap flux responses are: water uptake partitioning such that cacao withdrew water mostly from the topsoil where small amounts of throughfall entering the gaps in the roof frequently rewetted the soil, potentially higher humidity near the cacao crowns than near taller Gliricidia crowns, uncoupling of cacao leafs from the atmosphere, and the potential acclimation of cacao roots to dry conditions. Both species' sap flux recovered after the experiment. Because net precipitation exceeded stand transpiration during most months of the throughfall reduction experiment while soil moisture was decreasing, Drainage was a main driver of changes in soil water content. After linking drainage and sap flux data it became clear that both species maintained high transpiration only where surplus water was available, as indicated by high drainage rates.

In summary, it can be said that plant sap flux and water use characteristics clearly differed between tree species in forest stands in Indonesia, Panama and the Philippines, but structural stand components such as shading regimes and tree exposure also influenced tree water use. The data further suggests that shade trees may increase and enhance stand transpiration both through their own water use and by increasing water use rates of associated cacao trees. This suggests that in addition to species selection, management practices are also valuable tools to manage stand water use in reforestations or agroforestry stands.

The throughfall reduction study showed that competition between cacao and Gliricidia for water resources during long periods with limited precipitation might be either minimal or slightly in favor of cacao. Water uptake partitioning and low stand transpiration rates may have reduced competition for available water resources and may have contributed to the relatively high tolerance of this agroforest to reduced throughfall. 


\section{KAKAO-AGROFORST UNTER NORMALEM UND REDUZIERTEM BESTANDESNIEDERSCHLAG: BAUMWASSERNUTZUNGSCHARAKTERISTIKEN UND BESTANDESWASSERBILANZ}

Die Waldflächen in vielen tropischen Regionen der Welt haben in den vergangenen Jahrzehnten drastisch abgenommen, und ein Ende dieses Trends ist bis heute nicht abzusehen. Dennoch gibt es auch Bestrebungen zur Wiederaufforstung ehemaliger Regenwaldflächen mit einheimischen oder exotischen Arten in Mischbeständen, kommerziellen Plantagen oder Agroforstsystemen, die eine Kombination von Bäumen und Sträuchern mit landwirtschaftlichen Kulturen und/oder Nutztieren darstellen. Wiederaufforstungen sind in vielerlei Hinsicht von großem Nutzen: Sie können in Form von kommerziellen Plantagen oder Agroforstsystemen zur Einkommenssicherung der lokalen Bevölkerung beitragen, dienen aber auch als Bindeglied zwischen Nationalparks und Kulturlandschaften und sind geeignet zur Erosionskontrolle sowie zum Rekultivieren degradierten Landes. Neben ihrem Nutzen zur Erhaltung der Biodiversität verfügen sie auch über ein großes $\mathrm{CO}_{2}$-Speicherpotential, was sie besonders aus der Sicht des Klimaschutzes interessant macht.

Trotz dieser Vorteile geraten Bestrebungen zur Wiederaufforstung aber auch häufig in die Kritik, weil sie durch hohe Evapotranspirationsraten im Vergleich zur vorhergehenden Vegetation die Grundwasserneubildung sowie den Oberflächenwasserabfluss verringern können. Das ist besonders problematisch in Gebieten, wo die Wasserressourcen ohnehin schon stark vom Menschen genutzt werden. Angesichts des Klimawandels könnte sich dieser Konflikt noch verschärfen, weil ein Anstieg von Häufigkeit und Stärke von Trockenzeiten in den (Sub-) Tropen erwartet wird. Um den Wasserverbrauch von Wiederaufforstungen zu verringern und um zukünftige Bestände gut an Dürreereignisse anzupassen, ist neben der Bestandesführung auch eine geschickte Wahl der Baumarten von essentieller Bedeutung. Leider gibt es bisher nur wenige Studien, die sich mit der Wassernutzung einzelner tropischer Bäume beschäftigen, auch wenn diese vielfach für Pflanzungen zum Einsatz kommen. Ebenso gibt es nur wenige Erkenntnisse über die Reaktion tropischer Baumarten oder ganzer Ökosysteme auf ungewöhnliche Trockenereignisse. Es bleibt aber generell fraglich, ob die Artwahl überhaupt großen Einfluss auf den Wasserverbrauch von Bäumen in ähnlichen Ökosystemen hat. Aktuelle Forschungsergebnisse aus tropischen Regenwäldern haben gezeigt, dass unter gegebenen klimatischen Bedingungen artunabhängige Beziehungen zwischen Baumdurchmesser und Wassernutzung bestehen. Allerdings gibt es bisher 
keine gleichartigen Studien, die ähnliche Abhängigkeiten in Wiederaufforstungen oder Agroforstsystemen belegen könnten.

Die vorgelegte Dissertation setzt sich anhand eines Feldexperiments in einem Kakao/Gliricidia-Agroforstsystem mit diesen offenen Fragestellungen auseinander. Saftflusscharakteristiken und Wassernutzungsraten wurden bestimmt und zwischen den Arten im Bestand sowie mit Arten aus anderen Beständen (Monokulturplantagen in Panama und Wiederaufforstungen in den Philippinen) verglichen. In einem zweiten Schritt wurde der Bestandesniederschlag für eine Zeit von 13 Monaten in drei Flächen der Kakaoplantage mit Hilfe von Plastikdächern um 71 \% im Vergleich zu drei Kontrollflächen verringert. Dabei wurden Veränderungen des Saftflusses der Bäume, der Bestandestranspiration sowie des Bodenwasserhaushalts, die sich aus dem reduzierten Niederschlag ergaben, mit einer Kontrolle unter normalen Niederschlagsbedingungen verglichen.

Die Fragestellungen der Arbeit waren:

1) Wie beeinflussen Baumstruktur, Baumart, Umweltbedingungen und Beschattung den Saftfluss und die Wassernutzung von Bäumen in Agroforstsystemen oder Wiederaufforstungen?

2) Gelten artunabhängige Beziehungen zwischen Baumdurchmesser und Wassernutzung, die in Naturwäldern nachgewiesen wurden, auch für Agroforstsysteme und Wiederaufforstungen in tropischen Regionen?

3) Wie werden Baumsaftfluss, Wassernutzung und Wasserbilanz des indonesischen Agroforstsystems durch künstlich reduzierten Bestandesniederschlag beeinflusst?

Die Feldarbeit zur Dissertation wurde im Rahmen des DFG-Projektes 'Stability of Rainforest Margins in Indonesia' (STORMA) durchgeführt. Daten für den Vergleich von Arten aus mehreren tropischen Beständen wurden von Kollegen der Arbeitsgruppe am Institut 'Tropical Silviculture and Forest Ecology' zur Verfügung gestellt. Die jeweiligen Beiträge einzelner Autoren werden im folgenden Kapitel (Overview publications) dargestellt. Die Arbeit besteht aus drei Publikationen (Kapitel 3-5):

In der ersten Veröffentlichung werden Einflüsse von Baumstruktur, Baumart und Umweltbedingungen wie Beschattung auf Saftfluss und Wassernutzung eines Kakao-/GliricidiaAgroforstsystems in Zentralsulawesi/Indonesien beschrieben. Die Saftflussdichte von 18 Bäumen pro Art wurde mit Granier-Xylem-Saftflusssensoren bei normalem Bestandesniederschlag bestimmt. Parallel wurden Wetterdaten und Daten zur Bodenfeuchte erhoben. Zur Auswertung der Daten wurde ein einfaches Jarvis-Modell benutzt, dass den Saftfluss in Beziehung zum Was- 
serdampfdruckdefizit der Luft und zur Globalstrahlung setzt. Die daraus resultierenden Modellparameter sowie kumulierten Saftflüsse wurden dann analysiert und in Beziehung zu Baumart und -struktur gesetzt.

In einer zweiten Publikation werden Saftflussdaten aus der Studie des indonesischen Agroforsts mit Daten aus einer Plantage in Panama (Bäume in Monokultur) und einer Wiederaufforstung in den Philippinen (Mischbestand) zusammengebracht. Anhand von 100 Bäumen aus 17 Arten wurde geprüft, ob generelle Zusammenhänge zwischen Baumstruktur und Wassernutzung für ähnliche Nutzungssysteme in verschiedenen tropischen Regionen bestehen, oder ob es Artunterschiede in der Wassernutzung und der Reaktion des Saftflusses auf Umweltparameter gibt.

Nach der Untersuchung des Saftflusses und der Wassernutzung von Kakao- und GliricidiaBäumen in dem indonesischen Agroforstsystem unter normalen Niederschlagsbedingungen wurde der Bestand in sechs Teilflächen untergliedert, von denen drei für einen Zeitraum von 13 Monaten mit Dachkonstruktionen bestückt wurden. Die Dächer aus Bambusstangen und durchsichtiger Folie verringerten den Bestandesniederschlag im Vergleich zu den verbleibenden drei Kontrollflächen um 71 \%. In einer dritten Studie werden dann die Auswirkungen des reduzierten Bestandesniederschlags auf Saftfluss und Wassernutzung der beiden Arten bzw. auf die Interaktionen zwischen den Arten beschrieben. Weiterhin wurde ein Bodenwasserhaushaltsmodell zur Beschreibung von Auswirkungen des reduzierten Bestandesniederschlags auf die Wasserbilanzen von normalem und reduziertem Bestandesniederschlagsszenario angewendet.

Die Hauptergebnisse waren:

1) Fundamentale Unterschiede zwischen den Saftflusscharakteristiken der beiden Spezies wurden bei der Anwendung des Jarvis-Saftflussmodells gefunden, obwohl die kumulierten täglichen Saftflüsse der Arten vergleichbar waren. Die Modellparameter ergaben, dass Kakao eine um 49 \% höhere maximale Saftflussgeschwindigkeit erreichte als Gliricidia. Ebenfalls waren Unterschiede des Saftflusses in Bezug auf Umweltparameter wie Strahlung und Wasserdampfdruckdefizit erkennbar, was offensichtlich der besseren Exposition der Gliricidia-Kronen geschuldet ist. Die Wassernutzungsraten beider Arten stiegen linear mit zunehmendem Durchmesser an, aber der Anstieg der Gliricidia-Wassernutzungsrate war im Vergleich zum Kakao weniger stark, was mit einer geringeren Saftholztiefe von Gliricidia erklärt wird. Die Bestandestranspiration lag im Mittel der 13 Monate bei $1.5 \mathrm{~mm} \mathrm{Tag}^{-1} .70 \%$ der Transpirationsleistung wurden dabei von Kakaobäumen erbracht. Entgegen den ursprünglichen Erwartungen vergrößerte sich der Wasserverbrauch der Kakaobäume mit zunehmender Beschattung, was offensichtlich mit gesteigertem vegetativem Wachstum in der Nähe von Schattenbäumen zu erklären ist. Dieses Ergebnis deutet 
darauf hin, dass die Bestandestranspiration von beschattetem Kakao im Vergleich zu Kakao in Reinkultur nicht nur wegen der Wassernutzung der Schattenbäume, sondern durch die Verstärkung des Wasserverbrauchs der Kakaobäume erhöht ist.

2) Aus der vergleichenden Analyse der Saftflussdaten von 100 Bäumen aus 17 Arten der Wiederaufforstungen in Panama und den Philippinen sowie des Agroforsts in Indonesien ergab sich eine Variation der maximalen Saftflussgeschwindigkeiten zwischen den Arten um den Faktor 3. Ebenfalls ergaben sich signifikante Saftflussdifferenzen zwischen den Arten innerhalb der jeweiligen Standorte. Die in der Literatur für Naturwälder beschriebene artunabhängige Beziehung zwischen Saftflussgeschwindigkeit und Baumdurchmesser konnte damit für tropische Wiederaufforstungen nicht bestätigt werden. Nachgewiesen wurde aber eine signifikante lineare Beziehung zwischen Baumdurchmesser und Wassernutzungsrate $\left(\mathrm{R}_{\text {adj }}^{2}=0.65\right)$. Allerdings wurden dabei bei gleichem Durchmesser deutliche Unterschiede in der Wassernutzung zwischen den Arten (um den Faktor 2) festgestellt, was auch darauf zurückzuführen ist, dass die Beziehung für einige Arten deutlich verschiedene Verläufe aufwies.

3) Die beiden Arten Kakao und Gliricidia reagierten unterschiedlich auf abnehmenden Bodenwassergehalt. Die Saftflussgeschwindigkeiten von Gliricidia Bäumen in den Dachflächen verringerten sich im Vergleich zu Kakao schon bei deutlich höheren Wassergehalten, und diese Saftflussreduktion war über den gesamten Bereich des gemessenen Wasserdampfdruckdefizits feststellbar. Im Gegensatz dazu zeigte sich eine Abnahme der Saftflussgeschwindigkeiten von Kakaobäumen in den Dachflächen nur bei hohem Wasserdampfdruckdefizit, während die Saftflussgeschwindigkeiten von Bäumen in Dach- und Kontrollflächen bei niedrigem Wasserdampfdruckdefizit ähnlich waren. Die Monatsmittel der Saftflussgeschwindigkeiten beider Arten nahmen linear mit sinkendem Bodenwassergehalt ab und waren dabei im Vergleich zur Kontrolle maximal 21\% (Kakao) bzw. 29\% (Gliricidia) reduziert. Mögliche Erklärungen für diese Unterschiede wurden in der vertikalen Aufteilung der Wasseraufnahme zwischen den Arten gesehen, wobei Kakao Wasser eher aus dem Oberboden entzog, der häufig durch kleinere Regenmengen, die durch Öffnungen im Dach fielen, befeuchtet wurde. Weiterhin war anzunehmen, dass die Luftfeuchte in der direkten Umgebung der Kakaokronen viel höher war als im oberen Teil des Bestandes, in dem sich die Kronen der Gliricidia entfalten. Zusätzlich adaptieren sich die Kakaowurzeln im Gegensatz zu Gliricidia durch osmotische Anpassung an den sinkenden Wassergehalt. Der Saftfluss beider Arten erholte sich nach Beendigung des Dachexperiments. Es konnte weiter gefolgert werden, dass die Drainage einen sehr großen Einfluss auf das Absinken des Bodenwasservorrats in den Dachflächen hatte, denn der Nettoniederschlag überstieg die Bestandestranspiration während der meisten Monate des Experiments. Hohe Transpirationsleistungen schienen 
bei beiden Arten an einen Überschuss an Bodenwasser gekoppelt zu sein, denn sie wurden nur bei hohen Drainageraten festgestellt.

Zusammenfassend ergab sich, dass ein klarer Arteinfluss auf die Wassernutzung von Bäumen in Wiederaufforstungen und Agroforstsystemen in Indonesien, Panama und den Philippinen nachgewiesen werden konnte. Die Wassernutzung wurde aber auch von der Bestandesstruktur (Beschattung, Exposition der Bäume) beeinflusst. Schattenbäume in Agroforstsystemen wirken sich in zweierlei Hinsicht auf den Wasserverbrauch aus. Einerseits erhöhen Schattenbäume die Bestandestranspiration um die eigene Transpirationsleistung, andererseits können sie auch den Wasserverbrauch der beschatteten Bäume erhöhen. Daher sind eine geschickte Artwahl und ein gute Bestandesführung (Beschattungsmanagement) geeignete Maßnahmen, um den Wasserverbrauch von Wiederaufforstungen und Agroforstsystemen zu steuern.

Die Studie zur künstlichen Reduktion des Bestandesniederschlags in einem Kakao/GliricidiaAgroforstsystem ergab, dass Kakao bei längeren Trockenperioden im Vergleich zu Gliricidia einen Vorteil in der Konkurrenz um Wasser hat, bzw. die Konkurrenz weniger stark ausgeprägt war. Mögliche Gründe für die relativ hohe Trockenheitstoleranz des Ökosystems sind die niedrige Bestandestranspiration, aber auch die offenbar getrennte Wasseraufnahme der Arten aus verschiedenen Bodenschichten. 


\section{OVERVIEW PUBLICATIONS}

\section{Publications given as chapters of this thesis}

\section{Water use characteristics of cacao and Gliricidia trees in an agroforest in Central Su- lawesi, Indonesia (Chapter 3)}

Michael Köbler, Diego Dierick, Luitgard Schwendenmann \& Dirk Hölscher (2009)

Ecohydrology 2, 520 - 529

The study was developed by Dirk Hölscher and Luitgard Schwendenmann and carried out within the framework of the joint research project "Stability of Rainforest Margins in Indonesia". The field set up and data collection was realised by the author. Data analysis was done jointly by the author and Diego Dierick who supported the author during his parental leave. Manuscript writing and preparation was done by the author and Diego Dierick with the assistance of Luitgard Schwendenmann and Dirk Hölscher.

Comparison of tree water use characteristics in reforestation and agroforestry stands across the tropics (Chapter 4)

Diego Dierick, Norbert Kunert, Michael Köhler, Luitgard Schwendenmann \& Dirk Hölscher (2010)

In: T. Tscharntke, C. Leuschner, E. Veldkamp, H. Faust, E. Guhardja, A. Bidin (Eds.), Tropical Rainforests and Agroforests under Global Change, Springer, Berlin, 293 - 308

This publication compares water use characteristics assessed in the cacao/Gliricidia agroforest in Indonesia with data from field studies in mixed reforestations in the Philippines and monospecific reforestations in Panama. The study was supervised by Dirk Hölscher, field work and data analyses were conducted by Diego Dierick (Philippines), Norbert Kunert (Panama) and the author (Indonesia). Diego Dierick was responsible for the manuscript with the help of all coauthors. 
Throughfall reduction in a cacao agroforest: tree water use and soil water budgeting (Chapter 5)

Michael Köbler, Luitgard Schwendenmann \& Dirk Hölscher

Agricultural and Forest Meteorology (in press)

Within this paper, sap flux and tree water use in the Indonesian agroforest under reduced throughfall are described in relation to declining soil moisture. Effects of reduced throughfall on stand water budget were assessed with a soil water budget model. Data analysis, modelling and manuscript writing was carried out by the author. Both co-authors commented on the manuscript. 


\title{
2. Further publications originating from work conducted in the framework of this dissertation
}

Three additional publications, to which the author of this dissertation substantially contributed, arose from work conducted for this $\mathrm{PhD}$ thesis in the framework of the interdisciplinary research project "STORMA". These publications, however, are not incorporated as separate chapters because their respective scope and the questions addressed differ from the overall objectives of this thesis. The abstracts of these publications are given for further reading and the author's contributions are described below.

\section{Can deuterium tracing be used for reliably estimating water use of tropical trees and bamboo?}

Schwendenmann, L., Dierick, D., Köbler, M., Hölscher, D.

Tree Physiology (in press)

\begin{abstract}
Reliable estimates of water use by trees and other woody plants are crucial for an improved understanding of plant physiology and for water resource management. Since the 1980s the thermal dissipation method (TDP) has been widely applied in trees, proved to be fairly accurate but is challenging in remote areas. Also in the $1980 \mathrm{~s}$ the deuterium $\left(\mathrm{D}_{2} \mathrm{O}\right.$ or deuterium oxide) tracing method was proposed, which so far has less often been applied. However, deuterium tracing requires less sophisticated equipment in the field and new analytical methods reduce costs and increase sample throughput. The objectives of this study were (1) to compare plant water use estimates of the TDP and $\mathrm{D}_{2} \mathrm{O}$ method, and (2) to determine whether the $\mathrm{D}_{2} \mathrm{O}$ method is appropriate for assessing absolute magnitudes of plant water use. The two methods were employed on five tropical tree species and a bamboo species growing in a reforestation stand in the Philippines and an agroforestry system in Indonesia. For bamboo, an increase of $\mathrm{D}_{2} \mathrm{O}$ values in neighboring, non-labeled culms suggests that $\mathrm{D}_{2} \mathrm{O}$ injected was partly redistributed among culms, which would seriously limit the accurate estimation of water use for the target culm. For trees, water use estimates resulting from the $\mathrm{D}_{2} \mathrm{O}$ tracing method were proportional to TDP results $\left(\mathrm{r}^{2}=0.85, \mathrm{p}<0.001\right)$, but absolute values were on average about 7 times higher. This overestimation may be due to the assumptions underlying the $\mathrm{D}_{2} \mathrm{O}$ tracing method, such as the conservation of tracer mass, not being met. Further, it cannot be excluded that underestimation of water use by the TDP method contributed partly to the observed difference. However, when considering known sources of error, a large part of the observed difference remains unexplained. Based on our results, the use of the $\mathrm{D}_{2} \mathrm{O}$ tracing method cannot be recommended without further experimental testing if absolute values of whole-plant water use are a major goal. However, the $\mathrm{D}_{2} \mathrm{O}$ tracing method appears suitable for answering other questions, such as relative differences in water use among trees, water redistribution among neighbors, and internal water transport and storage processes in plants.
\end{abstract}

The author conducted fieldwork in Indonesia that was used in this study, including the assessment of tree sap flux and deuterium labeling. Sap flux calculations were also contributed, and commentary was given on the manuscript. 


\title{
Effects of an experimental drought on the functioning of a cacao agroforestry system, Sulawesi, Indonesia.
}

Schwendenmann, L., Veldkamp, E., Moser, G., Hölscher, D., Köhler, M., Clough,Y., Anas, I., Dja-jakirana, G., Erasmi, S., Hertel, D., Leitner, D., Leuschner, C., Michalzik, B., Propastin, P., Tjoa, A., Tscharntke, T., van Straaten, O. (2010)

Global Change Biology 16, 1515-1530

\begin{abstract}
Agroforestry systems may play a critical role in reducing the vulnerability of farmers' livelihood to droughts as treebased systems provide several mechanisms that can mitigate the impacts from extreme weather events. Here, we use a replicated throughfall reduction experiment to study the drought response of a cacao/Gliricidia stand over a 13-month period. Soil water content was successfully reduced down to a soil depth of at least $2.5 \mathrm{~m}$. Contrary to our expectations we measured only relatively small nonsignificant changes in cacao (11\%) and Gliricidia (12\%) sap flux densities, cacao leaf litterfall (18\%), Gliricidia leaf litterfall $(2 \%)$, soil carbon dioxide efflux (14\%), and cacao yield $(10 \%)$ during roof closure. However, cacao bean yield in roof plots was substantially lower $(45 \%)$ compared with control plots during the main harvest following the period when soil water content was owest. This indicates that cacao bean yield was more sensitive to drought than other ecosystem functions. We found evidence in this agroforest that there is complementary use of soil water resources through vertical partitioning of water uptake between cacao and Gliricidia. This, in combination with acclimation may have helped cacao trees to cope with the induced drought. Cacao agroforests may thus play an important role as a drought-tolerant land use in those (sub-) tropical regions where the frequency and severity of droughts is projected to increase.
\end{abstract}

The author provided and analyzed data on climate, soil water content, soil water storage, and sap flux characteristics, all of which were gathered in the agroforest in Indonesia. Help was also given in the preparation of the manuscript. 


\title{
Spatial and temporal effects of drought on soil $\mathrm{CO} 2$ efflux in a cacao agroforestry system in Sulawesi, Indonesia
}

van Straaten, O., Veldkamp, E., Köhler, M., Anas, I.,

Biogeosciences 7, 1223-1235

\begin{abstract}
Climate change induced droughts pose a serious threat to ecosystems across the tropics and sub-tropics, particularly to those areas not adapted to natural dry periods. In order to study the vulnerability of cacao (Theobroma cacao) - Gliricidia sepium agroforestry plantations to droughts a large scale throughfall displacement roof was built in Central Sulawesi, Indonesia. In this 19month experiment, we compared soil surface $\mathrm{CO}_{2}$ efflux (soil respiration) from three roof plots with three adjacent control plots. Soil respiration rates peaked at intermediate soil moisture conditions and decreased under increasingly dry conditions (drought induced), or increasingly wet conditions (as evidenced in control plots). The roof plots exhibited a slight decrease in soil respiration compared to the control plots (average $13 \%$ decrease). The strength of the drought effect was spatially variable - while some measurement chamber sites reacted strongly (responsive) to the decrease in soil water content (up to $\left.\mathrm{R}^{2}=0.70\right)(\mathrm{n}=11$ ), others did not react at all (non-responsive) $(\mathrm{n}=7)$. A significant correlation was measured between 'responsive' soil respiration chamber sites and sap flux density ratios of cacao $(\mathrm{R}=0.61)$ and Gliricidia $(\mathrm{R}=0.65)$. Leaf litter $\mathrm{CO}_{2}$ respiration decreased as conditions became drier. The litter layer contributed approximately $3-4 \%$ of the total $\mathrm{CO}_{2}$ efflux during dry periods and up to $40 \%$ during wet periods. Within days of roof opening soil $\mathrm{CO}_{2}$ efflux rose to control plot levels. Thereafter, $\mathrm{CO}_{2}$ efflux remained comparable between roof and control plots. The cumulative effect on soil $\mathrm{CO}_{2}$ emissions over the duration of the experiment was not significantly different: the control plots respired $11.1 \pm 0.5 \mathrm{MgC} \mathrm{ha}^{-1} \mathrm{yr}^{-1}$, while roof plots respired $10.5 \pm 0.5$ $\mathrm{MgC} \mathrm{ha}{ }^{-1} \mathrm{yr}^{-1}$. The relatively mild decrease measured in soil $\mathrm{CO}_{2}$ efflux indicates that this agroforestry ecosystem is capable of mitigating droughts with only minor stress symptoms.
\end{abstract}

The author provided data on soil water content and sap flux density, modeled soil water drainage data, and provided feedback on the manuscript. 


\section{CHAPTER 1 \\ INTRODUCTION}
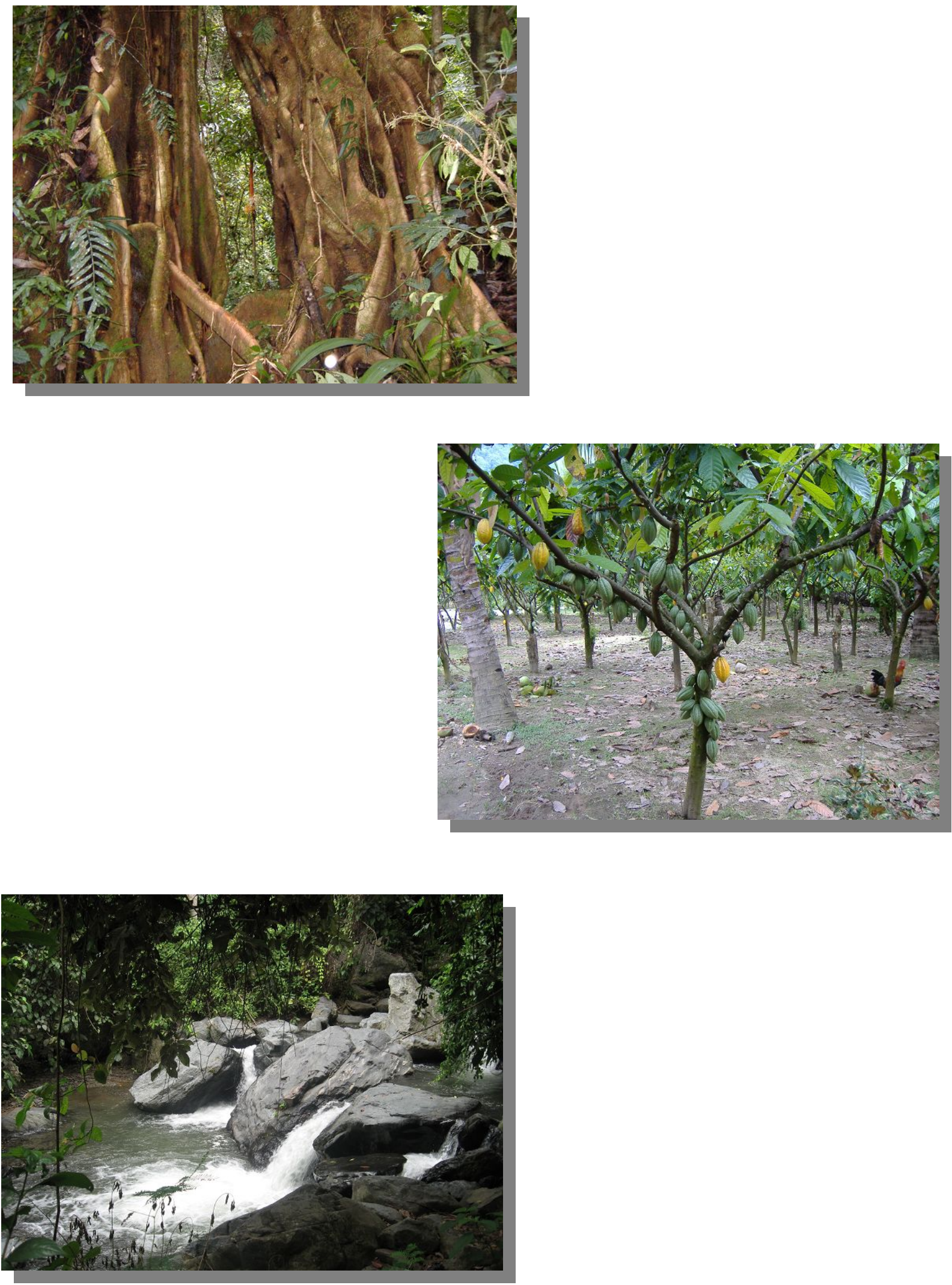
The tropical regions of the world have faced dramatic losses in forest cover and are still subject to high rates of rainforest conversion today. Since 1980, 288 million hectares of tropical rainforests (21\% of the global cover) have been deforested (Bawah et al., 2004). But alongside deforestation, there are also growing efforts to re-establish forest on formerly deforested lands with the goal of mitigating problems such as loss of biodiversity, soil degradation, erosion, flooding and salinization which often occur in deforested areas. Reforestation in tropical regions also presents an opportunity to increase global carbon sequestration (Canadell and Raupach, 2008). Although considerable credit is given to the natural regrowth potential of cleared forest areas, especially adjacent to remnant forest (Uhl et al, 1988; Woodford, 2000), the active planting of trees is the most common reforestation method (Catterall at al., 2004). The FAO recently reported that the rate of rainforest conversion has slowed due to both increased reforestation and regeneration (FAO, 2005). A wide range of reforestation methods exist, spanning from attempts to restore rainforest-like vegetation (e.g. Freebody and Vize, 1999) to the installation of commercial tree monocultures. Much attention is given to mixed reforestation stands which are comprised mainly of native species but also often include exotic species. Such stands can strike a balance between the ecological benefits of natural rainforest-like vegetation and the productive efficiency of tree monocultures. Mixed stands can be adapted to specific sites, growing conditions, and end uses through the choice of species used (Butterfield, 1995; Hartley, 2002; Piotto et al., 2004). There is evidence that mixed stands may be more productive than monocultures (Erskine et al., 2006; Piotto, 2008) and can potentially harbor high levels of biodiversity (Leakey, 1999; Hartley, 2002). Nonetheless, the need for income generation and/or food security for the local population is a crucial consideration if reforestation is to be successful.

Agroforests, which are combinations of shade trees and crops, present great potential for combining the conservation of tropical biodiversity with economically beneficial production (Schroth et al., 2004). Among other agroforestry systems, the traditional production of cacao and coffee offer a "glimpse of hope" to conservationists because both can be grown in "natural forest like" conditions under a variety of shade trees. Furthermore, these crops are also of high economic importance and therefore provide a valuable compromise between conservation of tropical forest biodiversity and income security for the local population (Rice and Greenberg 2000; Clough et al., 2009). Ironically, the extension of cacao production is a driver of deforestation in West Africa and Indonesia. However, with political will and good institutional measures, cacao agroforestry could provide a means to establish buffer zones around natural reserves or to promote reforestation on deforested land (Rice and Greenberg, 2000). Another benefit is discussed by Verchot et al. (2007), who emphasizes that agroforestry can provide a means for tropical agri- 
cultural production to adapt to climate change and thereby decrease the vulnerability of local populations. The potential of agroforests to adapt to reduced precipitation is of particular importance since it is predicted that global warming will increase the frequency and/or severity of droughts in the (sub-) tropics (Sheffield and Wood, 2008). Agroforests' improved resiliency to drought is seen mainly in trees' capacity to draw water from deeper soil layers and in the provision of shade to main crops (Verchot et al., 2007). It is well known that deep rooting systems enable trees to maintain high transpiration rates throughout dry spells by allowing access to deep soil water storage (Jipp et al., 1998; Klinge et al., 2001; Sommer et al., 2003). Additionally, the passive transport of water via tree roots from wet to dry soil, a process also referred to as "hydraulic redistribution" (Caldwell and Richards, 1989; Dawsen, 1993; Burgess at al., 1998), might help associated crops to withstand drought events. However, the specific nature of interaction between species (complementary water use or competition for water) in agroforestry is heavily dependent on species selection, tree spacing, and other management practices (Schroth, 1999). A method commonly used to study the ecosystem scale effects of water limitation in forested areas is the artificial reduction or exclusion of canopy throughfall by means of plastic roofs installed below the tree crowns. In tropical regions, such experiments have, up to this point in time, only been conducted in natural rain forests (Nepstad et al., 2002; Belk et al., 2007; Fisher et al., 2007). The way in which other vegetation types react to water limitation cannot be generalized from these experiments, especially because hydrological regimes are expected to undergo large changes following rainforest conversion (Bruijnzeel, 1996). These effects may be attributed to specific interception characteristics of the planted vegetation (see Zhang et al., 1999), to differences of water use characteristics of planted exotic trees compared to native species, but also to the specific stand structure of planted forests like the limited diameter range of trees and the homogenous layout of the stands. In particular, the role of agroforests in buffering against impacts of climate change, such as increased droughts, is still poorly understood (Verchot et al., 2007).

It is, however, quite certain that the characteristics of agroforests and reforestations described above are contributing to a heated debate. While on the one hand these land use systems allow for better use of stored soil water and mitigate drought effects, on the other hand, there is also evidence that reforestation of grassland, agricultural fields or other land use types into tree based land use may decrease stream water flow and groundwater recharge (Bruijnzeel, 2004; Jackson et al., 2005; van Dijk and Keenan, 2007). A global synthesis of relevant studies concluded that annual runoff was on average reduced by $44 \%$ and by $31 \%$ when reforesting grassand shrubland, respectively (Farley et al., 2005). In addition to hydraulic redistribution and deep rooting systems, a series of other mechanisms are responsible for the different hydrological be- 
havior of forest (-like) vegetation as compared to other vegetation types. Most importantly, forests generally exhibit higher evapotranspiration rates than grass or crop dominated vegetation, an effect due to strong coupling to the atmosphere, low albedo and high leaf area (Zhang et al., 1999). The rough and dense canopy of forested areas causes high interception rates and fosters evapotranspiration. A compilation of 250 water balance studies from catchments around the world with varying types of vegetative cover reveals the strong influence of vegetation on evapotranspiration, especially in tropical areas with high rainfall (Figure 1, Zhang et al., 1999).

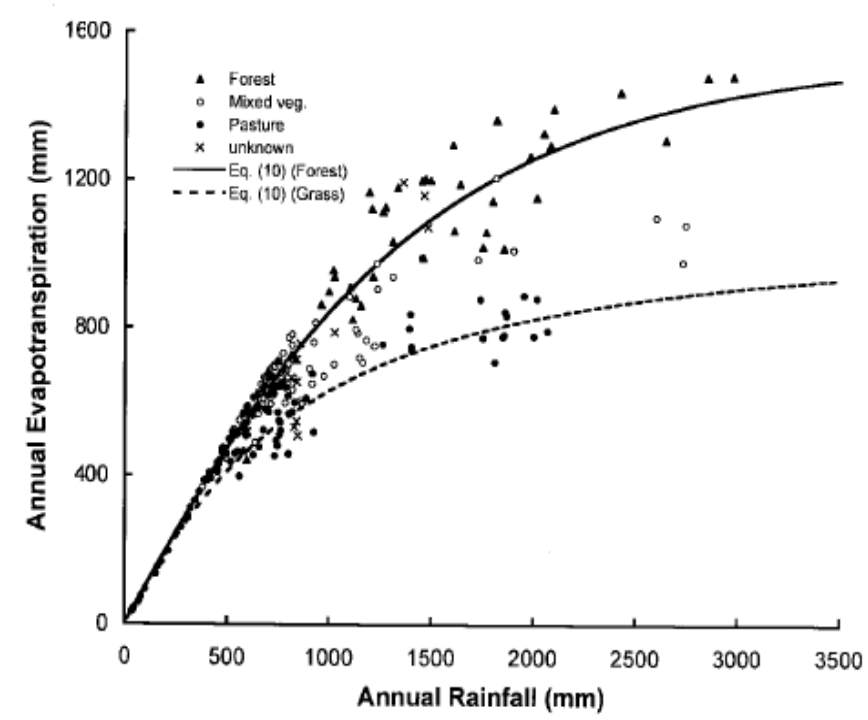

Figure 1: Relationship between annual evapotranspiration and rainfall for different vegetation types (Adapted from Zhang et al., 1999)

Vegetation characteristics and species mixture also exert strong influence on forest hydrology and water use itself (Zhang et al., 1999; Bigelow, 2001; Bruijnzeel, 2004; van Dijk and Keenan, 2007; Malmer et al., 2010). This may explain the considerable scatter around the upper curve in Figure 1. Unfortunately, the appropriate species selection to balance both production goals and water consumption is difficult to determine due to limited knowledge about the water use characteristics of trees, even species commonly used for reforestation or agroforestry (Bruijnzeel, 2004). For example, in the case of cacao, one of the most important cash crops throughout the tropics, this author's search revealed only a single study (Colas et al., 1999) assessing the water use of individual trees in relation to environmental components and stand characteristics. Further, only one such study could be found for Gliricidia sepium, a leguminous shade tree widely used in agroforestry (Tournebize and Boistard, 1998).

Even more problematic is that recent studies in old-growth forests suggest that water use rates of different trees species share a joint relationship with physical characteristics such as sap- 
wood area and stem diameter or tree biomass (Meinzer et al., 2001; Meinzer et al., 2005; McJannet et al., 2007). Meinzer et al. (2001) found strong positive correlations between tree diameter and active sapwood area, as well as strong negative correlations between tree diameter and maximum or total daily sap flux density for 24 tree species in an old growth tropical rainforest in Panama. Since tree water use is calculated from sap flux density and active sapwood area, these findings would imply that species selection has no influence on tree water use rates. Two other studies confirmed this finding for Australian rainforests (McJannet et al., 2007) and for 23 tropical and temperate tree species in a cross continental comparison (Meinzer et al., 2005), although the latter study also suggested that different relations exist for particular functional groups. These findings do support the hypothesis that plants exposed to similar environmental conditions might develop similar physiological adaptations (Meinzer, 2003).

However, other studies have found that sap flux density increases with tree size (Granier et al., 1996; Oren et al., 1999), which is directly contradictory to findings of Meinzer et al. (2001), while other studies found no relation at all (Phillips et al., 1999). In addition, since the studies of Meinzer et al. (2001), Meinzer et al. (2005), and McJannet et al. (2007) were conducted studies in old growth forests, it is questionable whether these results can be applied to reforestations or agroforests where tree diameters are generally smaller. It is also important to consider that tree distribution, tree height and two dimensional growing spaces in man made vegetation systems are homogenous, and such conditions might emphasize species differences. Particularly in agroforests, shading regimes (van Kanten and Vaast, 2006) and specific complementary effects (Rao et al., 1997) might also exert considerable influence on tree water use.

The first objective of the research conducted for this dissertation was to contribute to the still incomplete body of knowledge on water use characteristics of commercially important tree species. For this purpose, a traditional cacao/Gliricidia agroforestry system in Central Sulawesi, Indonesia was chosen as the site for an extensive study aimed at identifying the arboreal and environmental structural factors influencing water use.

Secondly, data was analyzed to find whether species selection could be an appropriate tool to manage water use rates in reforestations and agroforests, or if universal rules relating tree size to water use found in old growth forests apply to these forest types as well. This question was addressed by compiling data from the Indonesian study with results from Panama and the Philippines, resulting in a cross continental comparison of more than 100 trees belonging to 17 species.

The final goal was then to examine how the agroforest ecosystem responds to reduced soil water availability. To this end, a replicated throughfall reduction experiment was conducted in 
the cacao/Gliricidia agroforest mentioned above. Net precipitation was reduced by $71 \%$ as compared to a control for 13 months. Trees' sap flux response to reduced throughfall was compared to that of the control. To fully understand the hydrological impacts of the reduced throughfall, we also analyzed the changes in stand level soil water partitioning, measured as changes in transpiration, as well as drainage and soil moisture storage, which we incorporated through the use of a simple soil water transport model.

\section{References}

Bawa, K.S., Kress, W.J., Nadkarni, N.M., 2004. Tropical ecosystems into the 21st century. Science 306, 227-228.

Belk, E. L., Markewitz, D., Rasmussen, T. C., Carvalho, E. J. M., Nepstad, D. C., Davidson, E. A., 2007. Modeling the effects of throughfall reduction on soil water content in a Brazilian Oxisol under a moist tropical forest. Water Resour. Res. 43, W08432.

Bigelow, S., 2001. Evapotranspiration modelled from stands of three broad-leaved tropical trees in Costa Rica. Hydrological Processes, 15, 2779-2796.

Bruijnzeel, L.A., 1996. Predicting the hydrological impacts of land cover transformation in the humid tropics: the need for integrated research. In: Gash, J.H.C., Nobre, C.A., Roberts, J.M., Victoria, R.L. (Eds.), Amazonian deforestation and climate. John Wiley \& Sons, New York, 15-55.

Bruijnzeel, L.A., 2004. Hydrological functions of tropical forests: not seeing the soil for the trees? Agriculture, Ecosystems and Environment, 104, 185-228.

Burgess, S.S.O., Adams, M.A., Turner, N.C., Ong, C.K., 1998. The redistribution of soil water by tree root systems. Oecologia 115, 306-311.

Butterfield R.P., 1995. Promoting biodiversity: Advances in evaluating native species for reforestation. Forest Ecology and Management, 75 (1-3), 111-121.

Caldwell, M.M., Richards, J.H., 1989. Hydraulic lift: water efflux from upper roots improves effectiveness ofwater uptake by deep roots. Oecologia 79, 1-5.

Canadell, J.G., Raupach, M.R., 2008. Managing Forests for Climate Change Mitigation. Science 320 no. 5882, 1456 1457.

Catterall, C. P., Kanowski, J., Wardell-Johnson, G. W., Proctor, H., Reis, T., Harrison, D., Tucker, N. I. J., 2004. Quantifying the biodiversity values of reforestation: perspectives, design issues and outcomes in Australian rainforest landscapes. In: Lunney, D. (Ed.), Conservation of Australia's forest fauna, vol. 2. Royal Zoological Society of New South Wales, Sydney, Australia, 359-393.

Clough, Y., Faust, H., Tscharntke, T., 2009. Cacao boom and bust: Sustainability of agroforests and opportunities for biodiversity conservation. Conservation Letters 2, 197-205.

Colas, H., Mouchet, S., Rey, H., Kitu, W.T., 1999. Une approche du comportement hybrique du cacaoyer (Theobroma cacao L.) par des mesures de flux de sève brute : comparaison entre une culture pure et une culture associée sous cocotier (Cocos nucifera L.) In: Efficacité de la production cacaoyère et la qualité du cacao au 21è. Actes. Lagos : Cocoa Producers' Alliance, 637-644. Conférence internationale sur la recherche cacaoyère. 12, 1996-1117/1996-11-23, Salvador de Bahia, Brésil. 
Dawson, T.E., 1993. Hydraulic lift and water use by plants-implications for water balance, performance and plantplant interactions. Oecologia 95, 565-74.

Erskine, P.D., Lamb, D., Bristow, M., 2006. Tree species diversity and ecosystem function: Can tropical multispecies plantations generate greater productivity? Forest Ecology and Management, 233, 205-210.

FAO, 2005. Global Forest Resources Assessment 2005. FAO Forestry Paper 147. FAO, Rome.

Farley, K.A., Jobbagy, E.G., Jackson, R.B., 2005. Effects of afforestation on water yield: a global synthesis with implications for policy. Global Change Biology 11, 1565-1576.

Fisher, R. A., Williams, M., da Costa, A. L., Malhi, Y., da Costa, R. F., Almeida, S., Meir, P., 2007. The response of an eastern Amazonian rain forest to drought stress: results and modelling analyses from a through-fall exclusion experiment. Glob. Change Biol. 13, 2361-2378.

Freebody, K., Vize, S., 1999. Local government's role in rainforest establishment and management in north Queensland. In: Boyes, B. (Ed.). 1998. Rainforest Recovery for the New Millennium, World Wide Fund for Nature South-East Queensland Rainforest Recovery Conference, WWF, Sydney, 198-205.

Granier, A., Huc, R., Barigah, S.T., 1996. Transpiration of natural rain forest and its dependence on climatic factors. Agricultural and Forest Meteorology, 78, 19-29.

Hartley, M. J., 2002. Rationale and methods for conserving biodiversity in plantation forests, Forest Ecology and Management, 155 (1-3), 81-95.

Jackson, B. J., Jobbagy, E. G., Avissar, R., Roy, S. B., Barrett, D. J., Cook, C. W., Farley, K. A., le Maitre, D. C., McCarl, B. A., Murray, B. C., 2005. Trading water for carbon with biological carbon sequestration. Science 310 , 1944-1947.

Jipp, P. H., Nepstad, D. C., Cassel, D. K., Reis de Carvalho, C., 1998. Deep soil moisture storage and transpiration in forests and pastures of seasonally-dry Amazonia. Climatic Change 39, 395-412.

Klinge, R., Schmidt, J., Fölster, H., 2001. Simulation of water drainage from a rain forest and forest conversion plots using a soil water model. Journal of Hydrology 246, 82-95.

Leakey, R. R. B., 1999. Agroforestry for biodiversity in farming systems. In: Collins, W.W., Qualset, C.O. (Eds.), Biodiversity in Agroecosystems. CRC Press, Boca Raton, USA, 127-145.

Malmer, A., Murdiyarso, D., Bruijnzeel, L. A., Ilstedt, U., 2010. Carbon sequestration in tropical forests and water: a critical look at the basis for commonly used generalizations. Global Change Biology, 16, 599-604

McJannet, D., Fitch, P., Disher, M., Wallace, J., 2007. Measurements of transpiration in four tropical rainforest types of north Queenland, Australia. Hydrological Processes, 21, 3549-3564.

Meinzer, F. C., Goldstein, G., Andrade, J. L., 2001. Regulation of water flux through tropical forest canopy trees: Do universal rules apply? Tree Physiology, 21, 19-26.

Meinzer, F. C., 2003. Functional convergence in plant responses to the environment. Oecologia, 134, 1-11.

Meinzer, F. C., Bond, B. J., Warren, J. M., Woodruff, D. R., 2005. Does water transport scale universally with tree size? Functional Ecology, 19, 558-565.

Nepstad D. C., Moutinho P., Dias-Filho M. B., Davidson E., Cardinot G., Markewitz D., Figueiredo R., Vianna N., Chambers J., Ray D., Guerreiros J. B., Lefebvre P., Sternberg L., Moreira M., Barros L., Ishida F. Y., Tohlver I., 
Belk E., Kalif K., Schwalbe K., 2002. The effects of partial throughfall exclusion on canopy processes, aboveground production, and biogeochemistry of an Amazon forest. J. Geophys. Res. 107, 53-1 - 53-18.

Oren, R., Phillips, N., Ewers, B. E., Pataki, D. E., Megonigal, J. P., 1999. Sap-flux-scaled transpiration responses to light, vapor pressure deficit, and leaf area reduction in a flooded Taxodium distichum forest. Tree Physiology, 19, 337-347.

Phillips, N., Oren R., Zimmermann, R., Wright, S.J., 1999. Temporal patterns of water flux in trees and lianas in a Panamanian moist forest. Trees 14, 116-123.

Piotto, D., Viquez, E., Montagnini, F., Kanninen, M., 2004. Pure and mixed forest plantations with native species of the dry tropics of Costa Rica: a comparison of growth and productivity. Forest Ecology and Management, 190, 359-372.

Piotto, D., 2008. A meta-analysis comparing tree growth in monocultures and mixed plantations. Forest Ecology and Management, 255, 781-786.

Rao, M. R., Nair, P. K. R., Ong, C. K., 1997. Biophysical interactions in tropical agroforestry systems. Agroforestry Systems 38, 3-50.

Rice, R. A., Greenberg R., 2000. Cacao cultivation and the conservation of biological diversity. Ambio 29, 167-173.

Schroth G., 1999. A review of belowground interactions in agroforestry, focusing on mechanisms and management options.Agroforest Syst 43: 5-34.

Schroth, G., da Fonseca, A. B., Harvey, C. A., Gascon, C., Vasconcelos, H. L., Izac, A. M. N., 2004. Agroforestry and Biodiversity Conservation in Tropical Landscapes. Island Press, Washington, USA.

Sheffield J., Wood, E. F., 2008. Projected changes in drought occurrence under future global warming from multimodel, multi-scenario, IPCC AR4 simulations. Clim. Dynamics 31, 79-105.

Sommer, R., Fölster, H., Vielhauer, K., Maklouf Carfvalho, E. J., Vlek, P. L. G., 2003. Deep Soil Water Dynamics and Depletion by Secondary Vegetation in the Eastern Amazon. Soil Sci. Soc. Am. J. 67, 1672-1686.

Tournebize R., Boistard S., 1998. Comparison of two sap flow methods for the estimation of tree transpiration, Ann. Sci. For. 55, 707-713.

Uhl, C., Buschbacher, R., Serro, E. A. S., 1988. Abandoned pastures in eastern Amazonia. I. Patterns of plant succession. Journal of Edology 76, 663 - 881.

van Dijk, A. I. J. M., Keenan, R. J., 2007. Planted forests and water in perspective. Forest Ecology and Management, $251,1-9$.

van Kanten, R., Vaast, P., 2006. Transpiration of arabica coffee and associated shade tree species in sub-optimal, low-altitude conditions of Costa Rica. Agroforestry Systems 67, 187-202.

Verchot, L. V., van Noordwijk, M., Kandji, S., Tomich, T. P., Ong, C. K., Albrecht, A., Mackensen, J., Bantilan, C., Anupama, K. V. Palm, C., 2007. Climate change: linking adaptation and mitigation through agroforestry, Mitig. Adapt. Strat. Glob. Change 12, 901-918.

Woodford, R., 2000. Converting a dairy farm back to rainforest: the Rocky Creek Dam story. Ecological Management and Restoration 1, 83-92. 
Zhang L., Dawes W. R., Walker G. R., 1999. Predicting the Effect of Vegetation Changes on Catchment Average Water Balance. Cooperative Research Centre for Catchment Hydrology, CSIRO Land and Water, Canberra, ACT, Australia. 


\section{CHAPTER 2}

METHODOLOGY
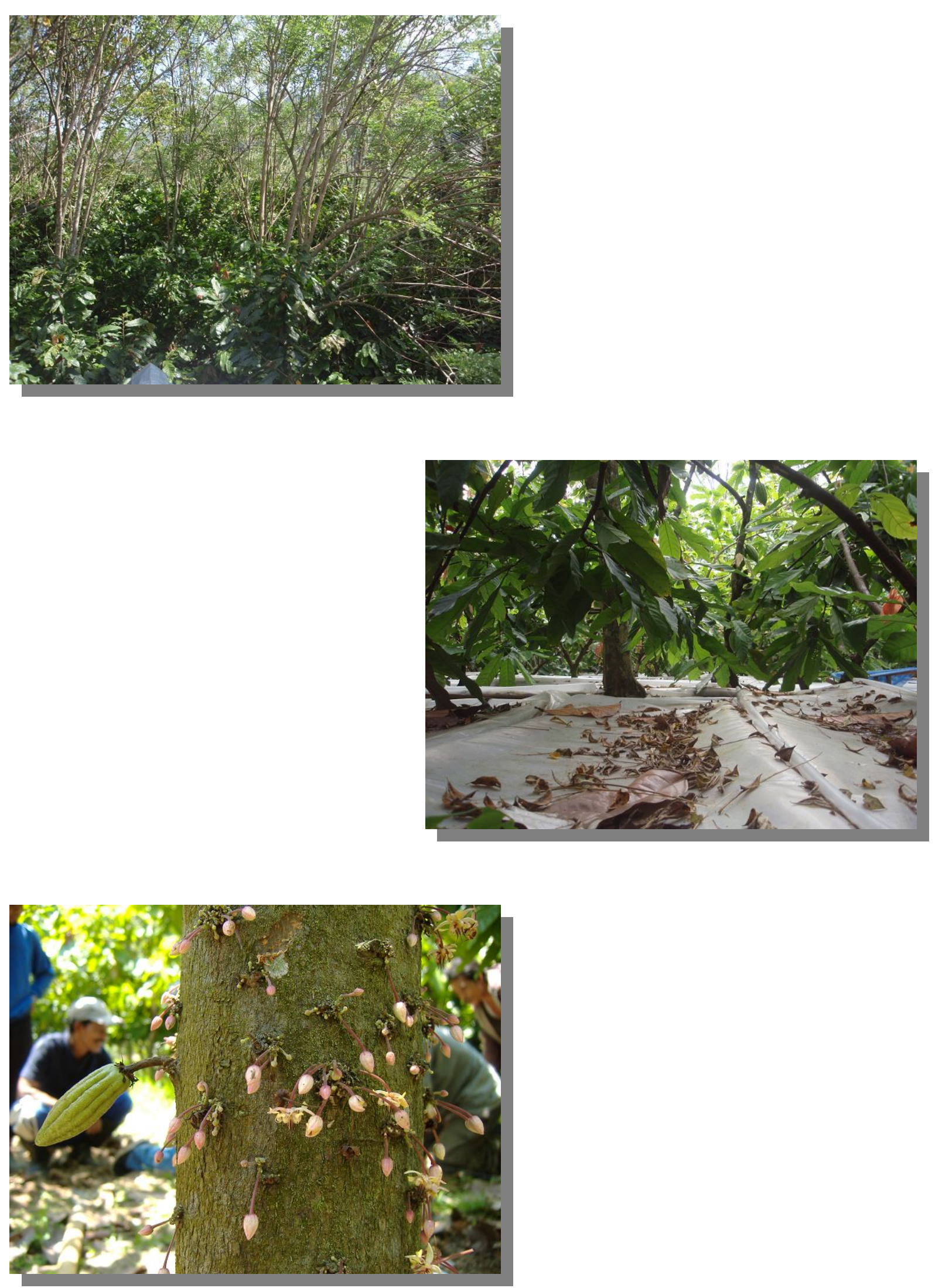


\subsection{Overview}

The general goal guiding the research presented in this dissertation was to describe the tree sap flux patterns, tree water use and overall stand transpiration of tropical woody vegetation and how these are affected by species type, tree structure, overall stand characteristics, and environmental conditions. To begin, sap flux patterns of cacao and Gliricidia trees were analyzed, employing data gathered from an agroforest located in Central Sulawesi, Indonesia. This work was conducted within the 'Stability of Rainforest Margins in Indonesia' project (STORMA). The next step was to compare the results of this study with similar observations made in other stands across the tropics. Data from the cacao agroforest in Indonesia was combined with data from additional stands, namely a mono-specific reforestation in Panama and a mixed reforestation stand in the Philippines (Figure 1), in order to gain a broader perspective of the water use characteristics of planted stands. Field work and data collection within these stands was conducted by the 'Tropical Silviculture and Forest Ecology' working group, namely Diego Dierick (Philippines) and Norbert Kunert (Panama).

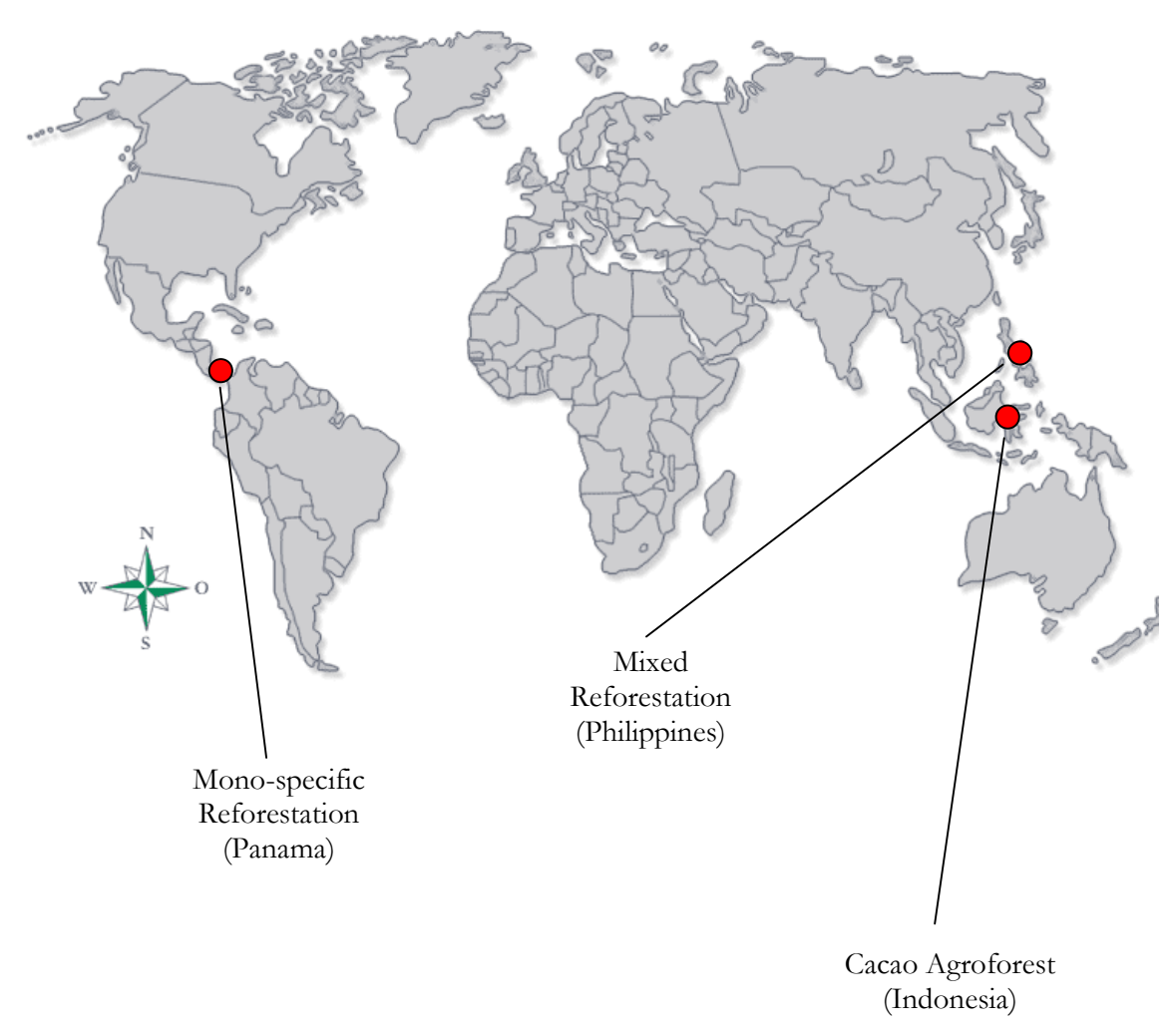

Figure 1: Study sites where data on sap flux was collected (Map adapted from www.mz1000s.de).

Within the framework of STORMA the author could also seize the chance to broaden the observations of sap flux response towards environmental factors with an experimental approach 
of whole ecosystem throughfall reduction, where effects of soil water availability on sap flux could be studied relatively independently of prevailing weather conditions in comparison to a control. The study could further be completed with the set up of a simple soil water transport model which gave valuable insight into soil water partitioning into infiltration, soil moisture storage change, root water uptake and drainage as affected by reduced canopy throughfall. The model was a useful tool to derive an understanding of the drought response of agroforestry stands on ecosystem scale and will be of future importance in studies of element cycles in the soil.

The first part of this methodology chapter now provides a description of the three different stands in which tree sap flux was studied. Information on climate conditions, potential and actual vegetation as well as on species selection are given. The next part delineates the set up of the throughfall reduction experiment conducted in Indonesia and continues with a comprehensive description of the field set up and the instrumentation used for assessing data on micrometeorological conditions, sap flux and soil water content. Herewith also a brief discussion on the theory of operation of sap flux sensors is given and measurement procedures are explained. Nearly identical set ups were used to collect the data in the Philippines and in Panama and analytical methods were the same.

The last part of this chapter is dedicated to the description of a sap flux model which is used as a diagnostic tool for species comparison and a soil water transport model applied to the Indonesian agroforest. For further details the reader should refer to the corresponding Material and Methods chapters of the publications given in chapters 3 to 5 of this thesis.

\subsection{Study sites and species selection}

In Indonesia, field work was conducted in a six-year-old cacao/Gliricidia agroforest located in the margin zone of the Lore Lindu National Park in Central Sulawesi in the vicinity of the village of Marena $\left(1.552^{\circ} \mathrm{S}, 120.020^{\circ} \mathrm{E}\right)$ at $560 \mathrm{~m}$ a.s.l. on a slope of $8-12^{\circ}$ inclination. Climate data from a nearby climate station (Gimpu, $5 \mathrm{~km}$ south of Marena at $471 \mathrm{~m}$ a.s.l.) collected between 2002 and 2006 revealed average annual temperatures of about $25.5^{\circ} \mathrm{C}$ and an annual precipitation of $2092 \mathrm{~mm} \mathrm{y}^{-1}$ (Kreilein, unpublished data). The soil type at the study site was described as a sandyloam Cambisol with high rock fragment content (Leitner, unpublished data). The potential vegetation of the study site would be submontane tropical rainforest (Dietz, 2007). This forest however was removed to clear areas for the production of annual crops (Pak Umar, pers. communication) which were converted to agroforestry later on following the cacao boom in Sulawesi. Ca- 


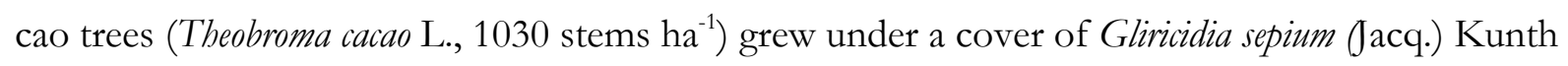
ex Steud shade trees (325 stems ha ${ }^{-1}$, Figure 2).
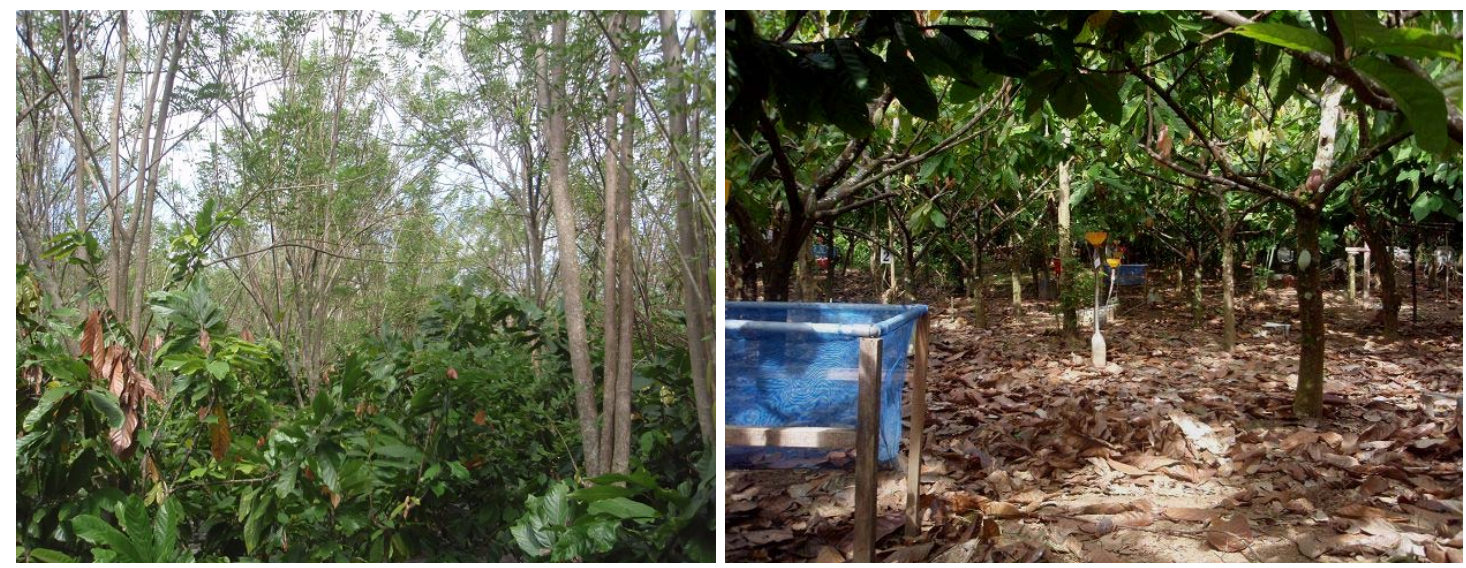

Figure 2: Cacao/Gliricidia agroforest in Central Sulawesi. Images taken above and below the cacao crowns.

The average tree height was 5.4 and $9.5 \mathrm{~m}$ for cacao and Gliricidia, respectively. Throughout the study period, cacao trees were pruned in July and December of 2007, while Gliricidia trees were not pruned. A total of 18 trees per species were selected for the study. Gliricidia trees were well exposed to the atmosphere and provided shade to cacao. The leaf area index of the stand measured $5.3 \mathrm{~m}^{2} \mathrm{~m}^{-2}$ (Propastin and Erasmi, unpublished data). The ground was free of an herbaceous understory due to low light availability below the canopy and regular weeding. No other agricultural operations but harvesting the cacao pods every two weeks were conducted. Measurements of micrometeorological conditions, tree sap flux and soil water dynamics under both ambient and reduced throughfall conditions were conducted here from February 1, 2007 to June 5, 2008.

For the cross species comparison of water use characteristics in planted forests (including agroforestry) we chose further stands located in Central Panama and in the Philippines. The Panamanian study site (Figure 3 A) was located near the village of Sardinilla, Central Panama $\left(9.317^{\circ} \mathrm{N}, 79.633^{\circ} \mathrm{W}, 70 \mathrm{~m}\right.$ asl.), about $50 \mathrm{~km}$ north of Panama City. Mean annual precipitation measured at Barro Colorado Island (at $30 \mathrm{~km}$ distance) was $2627 \mathrm{~mm}$, with a distinct dry season (25-50 $\mathrm{mm} \mathrm{month}^{-1}$ from January-March). During the rainy season (May to November) monthly precipitation was $250 \mathrm{~mm}$. The mean annual temperature of the region is $25.9^{\circ} \mathrm{C}$ (STRI, 2009). The original forest vegetation at the Sardinilla site was probably a tropical moist forest, similar to that of the Barro Colorado National Monument (Leigh et al., 1996). The study site was clear-cut in the 1950's, later used for cropping followed by cattle ranging and replanted in an experimental approach with native tree species in monocultures. At the time of the study, the stands were 6

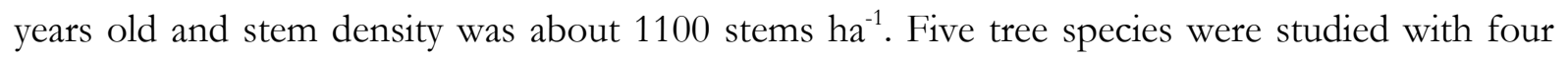
replicates each during the rainy season between June and September 2007. These species were 
Anacardium excelsum Beberto \& Balb. ex Kunth, Hura crepitans L., Cedrela odorata L., Tabebuia rosea (Bertol) D. C. and Lueha seemannii Triana \& Planch.

The study site on the Philippines (Figure 3 B) was located on Leyte Island in the Eastern Visayas. At a climate station at the Visayas State University, Visca, about 2-3 km distant from the two plots in which the study was conducted, annual average temperature measured $27.5{ }^{\circ} \mathrm{C}$ and annual precipitation was $2753 \mathrm{~mm} \mathrm{y}^{-1}$ (PAGASA, 2007). The former natural vegetation in the region was a species rich lowland dipterocarp rainforest (Langenberger, 2006), which was almost completely removed by human action. Following the so-called "rainforestation" approach, degraded areas where reforested with a mixture of mostly native tree species combining fast growing and shade tolerant species. Two 12-year-old rainforestation sites were chosen for the study.

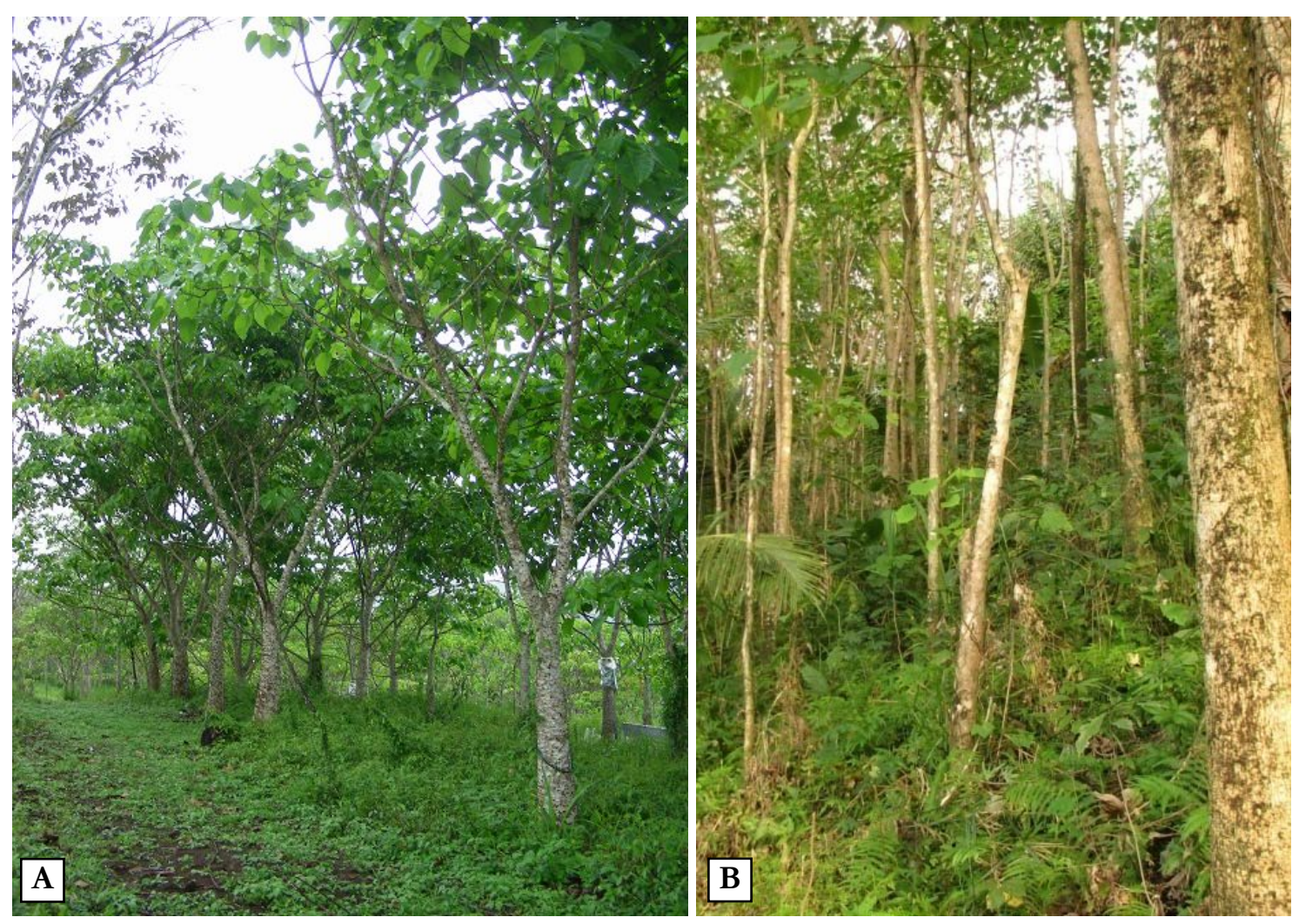

Figure 3: Mono-specific reforestation in Panama (A) and mixed reforestation in the Philippines (B). Images by Norbert Kunert (A) and Diego Dierick (B).

Sap flux and water use rates were assessed in ten tree species, eight of which were native to the region. Native species were Shorea contorta S. Vidal, Parashorea malaanonan Merr., Hopea malibato Foxw. and Hopea plagata S. Vidal, Vitex parviflora A. L. Juss, Myrica javanica Blume., Sandoricum koetjape (Burmf.) Merr. and Durio zibethinus Murray. The exotic species Swietenia macropbylla King (large-leaved mahogany) and Gmelina arborea Roxb. (gmelina or yemane) included in the study are commonly planted throughout the tropics. Gmelina however, was not present in the studied re- 
forestations, but grew in an adjacent plot under comparable site conditions in a 12 -year-old stand. Five individuals per species were chosen for the study and care was taken to select only trees having well exposed crowns. The study in the Philippines was conducted from November 2005 to September 2006 and from November 2006 to September 2007.

\subsection{Experimental design of throughfall reduction}

In the throughfall reduction experiment in Indonesia, throughfall reduction plots (hereafter called 'roof plots) and control plots were laid out in three replicates across the 1-ha area of the study site (Figure 4).

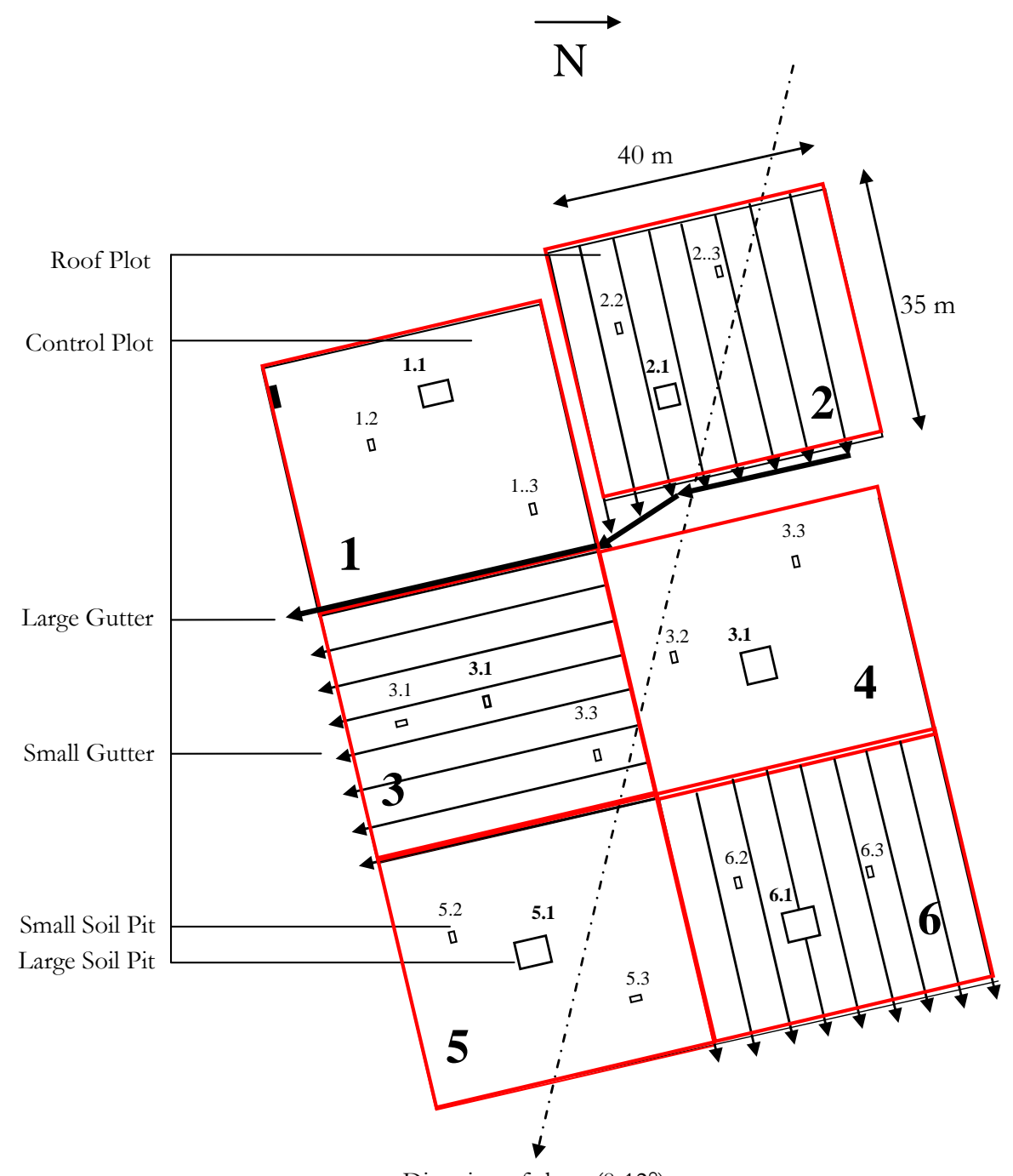

Direction of slope $\left(8-12^{\circ}\right)$

Figure 4: Plot map of the cacao/Gliricidia agroforest Central Sulawesi, Indonesia, larger numbers denote to plots (outlined in red), small numbers to soil pits within each plot. Each plot measures $35 \times 40 \mathrm{~m}$ (Figure adapted from G. Moser, unpublished)

One large $(80 \times 160 \times 300 \mathrm{~cm})$ and two small $(80 \times 100 \times 250 \mathrm{~cm})$ soil pits were dug inside of each plot in order to conduct measurements of soil water content. The trees used for sap flux 
density measurements were located in proximity to those soil pits. Each of the six plots measured $40 \times 35 \mathrm{~m}$. All measurements were conducted in a central 'core zone' $(30 \times 25 \mathrm{~m})$ to avoid margin effects. Water intrusion by overland flow to the roof plots was prevented by a $40 \mathrm{~cm}$ deep trench. Since most of the fine roots were located in the upper $40 \mathrm{~cm}$, the trenching also hindered root water uptake from surrounding plots.

Throughfall was partially excluded using panels made of clear polyethylene foil clamped on bamboo frames $(0.5 \times 5 \mathrm{~m})$. The panels were mounted at an average height of about $1.2 \mathrm{~m}$ above ground just below the branching point of cacao trees such that they drained into plasticlined, wooden gutters by gravity (Figure 5). The gutters discharged the water from the plots into an adjacent downhill area. A total of about $80 \%$ of the plot area of the roof plots was covered by bamboo frames and wooden gutters when the roof was finished.
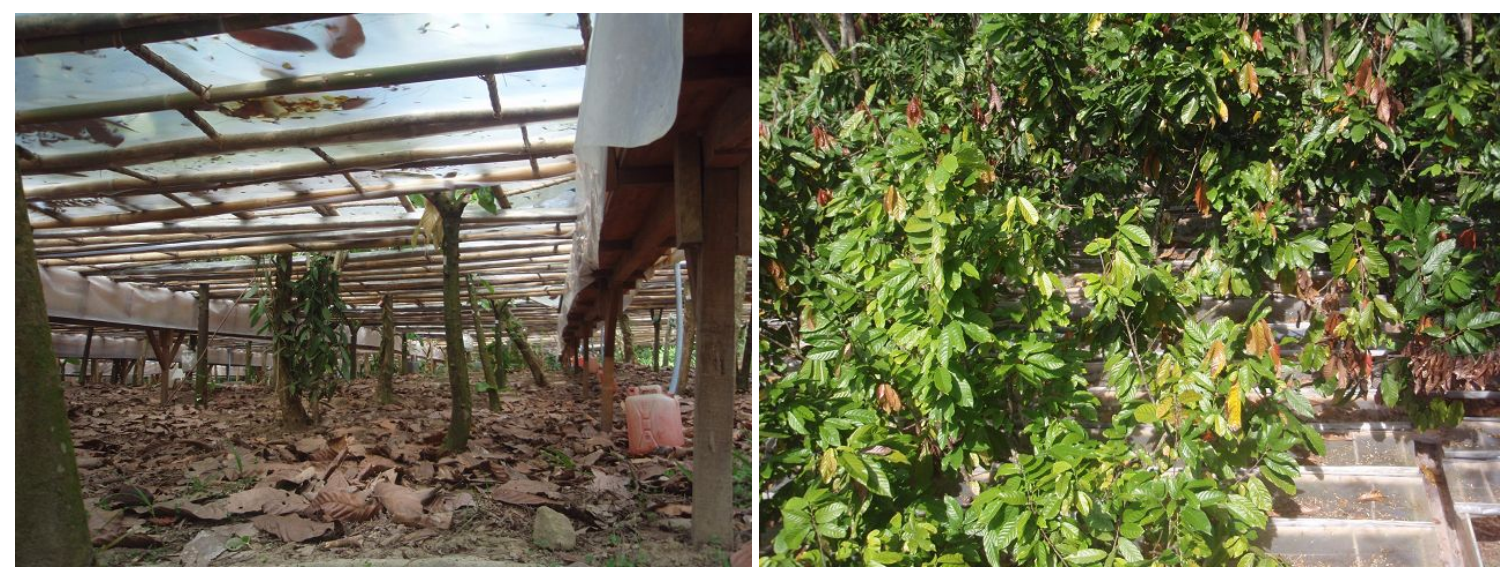

Figure 5: Picture from below and from above the roof installed in the cacao/Gliricidia agroforest in Indonesia.

The throughfall reduction experiment began after the recording of a baseline dataset during February 2007 on March 1, 2007. Especially during March and April 2007, roof coverage was lower due to the still ongoing process of setting up the roof (Table 1). 
Table 1: Average monthly throughfall reduction $(\%)$ in roof plots (data from G. Moser, unpublished).

\begin{tabular}{lc}
\hline Month & $\begin{array}{c}\text { Throughfall } \\
\text { reduction }(\%)\end{array}$ \\
\hline March 2007 & 47.5 \\
Apr & 58.8 \\
May & 78.1 \\
June & 83.8 \\
July & 79.9 \\
Aug & 82.8 \\
Sep & 73.1 \\
Oct & 79.0 \\
Nov & 81.3 \\
Dec & 75.0 \\
Jan 2008 & 81.8 \\
Feb & 66.2 \\
March & 81.8 \\
Apr & 44.6
\end{tabular}

However, even after full roof coverage was established, small gaps remained around tree stems and in between the frames. The roof coverage was about 80\% until April 10, 2008, where the roof was opened. The low throughfall reduction percentage given for April 2008 in Table 1 is a result of averaging throughfall reduction percentages of all days of this month while the roof was being removed after 10 days.

\subsection{Field set up and instrumentation}

The most important component of the field set up for all three sites was the installation of sap flux $\left(J_{s}, \mathrm{~g} \mathrm{~cm}^{-2} \mathrm{~h}^{-1}\right)$ sensors. Additional instrumentation consisted of an automated weather station installed in a nearby open area to collect global radiation $\left(R_{g}, \mathrm{~J} \mathrm{~m}^{-2} \mathrm{~s}^{-1}\right)$, relative humidity $(\mathrm{RH}, \%)$, air temperature $\left(T_{\text {air }},{ }^{\circ} \mathrm{C}\right)$, and gross precipitation $\left(P_{\text {gross }}, \mathrm{mm}\right)$, and a soil water monitoring system comprised of up to 72 sensors to measure volumetric soil water content $\left(\theta, \mathrm{cm}^{3} \mathrm{~cm}^{-3}\right)$. In the following section, the author describes the field set up and instrumentation used in Indonesia. Since field set ups were similar for the study sites in Panama and the Philippines, further details are not given for these studies.

\subsubsection{Micrometeorological measurements}

Data on air humidity, air temperature (CS215, Campbell Scientific Inc., Logan, UT, USA), global radiation (CS300, Apogee Instruments Inc., Logan, UT, USA) and rainfall (ARG100, Environmental Measurements Ltd., Sunderland, UK) were gathered at a distance of $30 \mathrm{~m}$ from the study site in an area where shade trees were absent. Measurements were taken at a height of $2 \mathrm{~m}$ above the canopy of cacao trees in order to assess environmental conditions prevalent in the up- 
per canopy. Data were measured every 5 seconds, and then averaged and logged in 30 min intervals using a CR800 data logger (Campbell Scientific Inc., Logan, UT, USA). Vapor pressure deficit $(\mathrm{VPD}, \mathrm{kPa}$ ) was calculated from air temperature and relative humidity following the precedent set by FAO (1998).

$\mathrm{VPD}=e_{s}-e_{a}$

where $e_{s}(\mathrm{kPa})$, the saturation vapor pressure of the air, is calculated as

$e_{s}=\frac{0.6108 \times \exp \left(17.27 \times T_{\text {air }}\right)}{\left(237.3+T_{\text {air }}\right)}$

and $e_{a}(\mathrm{kPa})$, the actual vapor pressure, is given by:

$e_{a}=\frac{e_{s} \times \mathrm{RH}}{100}$

Measured global radiation values indicated that the global radiation sensor underestimated real values from October 2007 onwards due to sensor malfunctioning. To recalibrate the malfunctioning sensor, reference measurements were conducted with two other sensors in June 2008. A linear regression was derived comparing the daily integrated global radiation measured by the reference sensors and the measurements taken by the malfunctioning sensor installed at the climate station. This linear regression was then used to correct the underestimated daily radiation measurements from October 2007 onwards. However, half hourly data could not be reproduced in this manner, so global radiation data was only used for the description of tree sap flux if measured prior to October 2007. It was also not possible to account for any gradual shifts in sensor calibration that might have occurred. This indicates that the accuracy of daily global radiation data obtained after October 2007 (given as monthly averages) may be questionable.

\subsubsection{Sapflux, tree water use, tree- and stand transpiration}

At all three study sides, sap flux density was measured using thermal dissipation sensors constructed after Granier (1985). Details on sensor construction (see Granier, 1985; Granier, 1987; Clearwater et al., 1999; James et al., 2002) are described briefly here. Each sensor consisted of a pair of probes, each probe having a diameter of $1.5 \mathrm{~mm}$ and a length of $24 \mathrm{~mm}$. The probes were inserted in tightly fitting aluminum tubes after receiving an application of heat conductive paste. The aluminum tubes were then inserted into predrilled holes in the outermost xylem layer of selected trees. The holes were spaced on average $15 \mathrm{~cm}$ apart in vertical direction (Figure 6). 


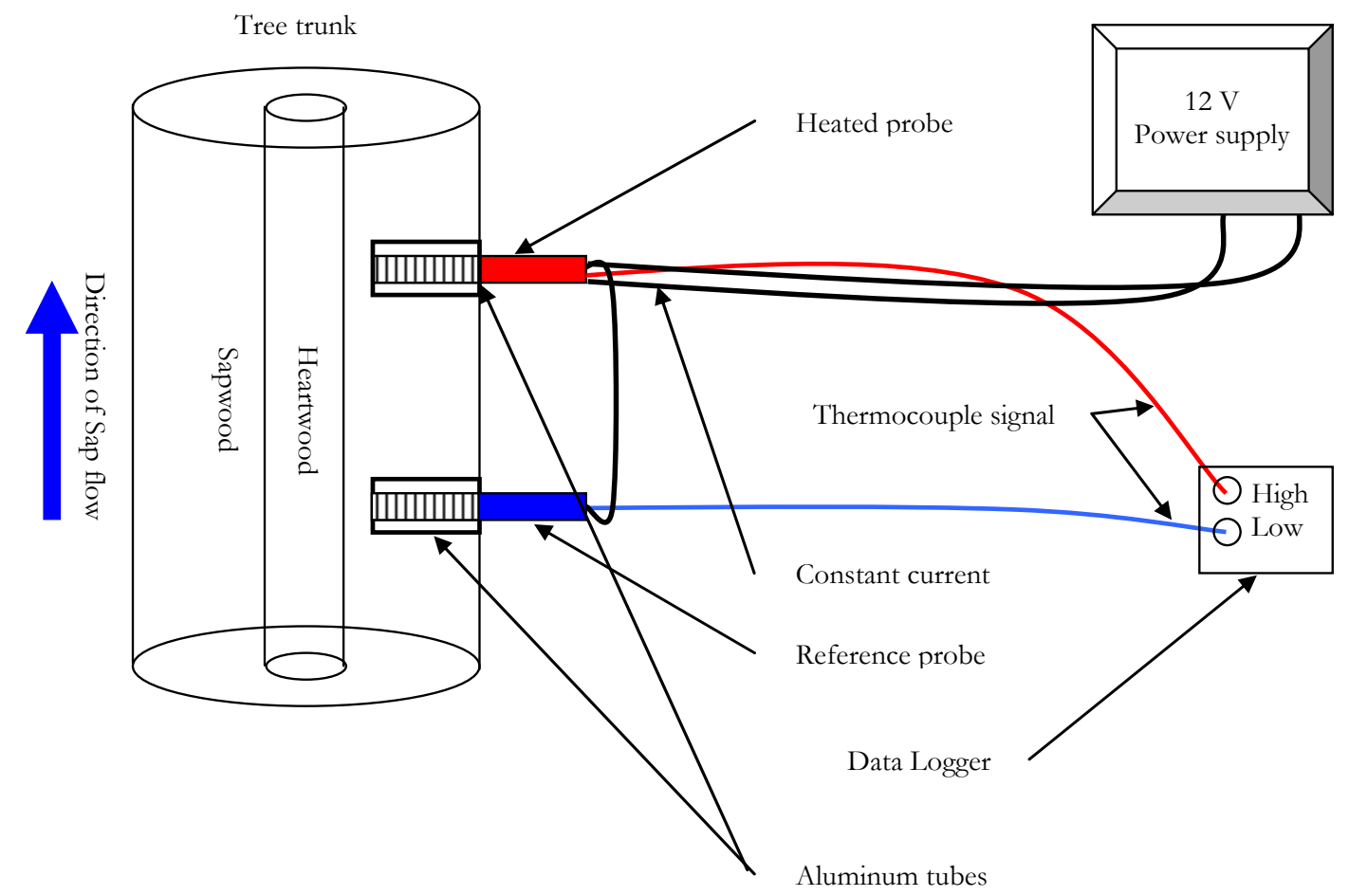

Figure 6: Configuration of the Granier system for sap flow measurement. Each probe contains a thermocouple. (adapted from Lu et al., 2004)

The upper (downstream) probe of each sensor was heated by a coil with a constant power of $250 \mathrm{~mW}$, while the lower (upstream) probe remained at the prevailing temperature of the stem. A copper-constantan junction was located in the center of each probe, and the junctions between probes were connected to form a thermocouple. When temperature differences between the two junctions occur, a current proportional to this difference is created and recorded by the data logger. The temperature difference between the sensors was measured every 30 seconds, and averaged and stored every 30 min (CR1000 data logger and AM 16/32 multiplexer, Campbell Scientific Inc., Logan, UT, USA.). The temperature differences measured between the probes are highly correlated with sap flux densities. With the onset of transpiration after sunrise leading to sap flux, temperature differences between the probes drop as heat from the downstream probe is transferred by convection. Temperature differences are of largest magnitude at night time, when no sap flux occurs. In our study, each tree was equipped with two sensors, usually located on both the North and South sides of the trunk, because sap flux is subject to circumferential variations (Lu et al., 2000). 
The temperature differences recorded were converted to sap flux density $\left(J_{s}, \mathrm{~g} \mathrm{~cm}^{-2} \mathrm{~h}^{-1}\right)$ by use of an empirically derived equation from Granier (1987):

$J_{s}=3600 \times 0.0119 \times\left(\frac{\Delta T_{\max }-\Delta T}{\Delta T}\right)^{1.231}$

Where $J_{s}$ is the sap flux density prevalent in the sapwood $\left(\mathrm{g} \mathrm{cm}^{-2} \mathrm{~h}^{-1}\right) ; \Delta T$ is the measured temperature difference $\left({ }^{\circ} \mathrm{C}\right)$; and $T_{\max }$ is the maximum temperature difference measured at time of zero flow $\left({ }^{\circ} \mathrm{C}\right)$. The sap flux densities calculated for each of the sensors within one tree were then averaged.

Granier (1985) recommended recalibration for each tree species. However, the recalibration procedure is very complex, and since it has been widely reported that the calibration is actually independent of tree species or wood anatomy (Granier et al., 1990; Lu et al., 2004), we did not attempt to recalibrate the probes. It was further assumed that nighttime sap flux densities were negligible because temperature outputs of the thermal dissipation sensors returned to stable values most nights, suggesting that internal reserves were completely refilled. Moreover, VPD at night was usually close to zero due to occurrence of rainfall most nights. Insulating boxes made from Styrofoam shielded the sensors, and for each installation a section of the stem, extending well above and below the installation point, was covered in reflective foil and plastic foil. These measures protected sensors against damage, prevented rainwater from entering the set up, and prevented incident solar radiation from heating the trunk and creating temperature gradients (Figure 7). 

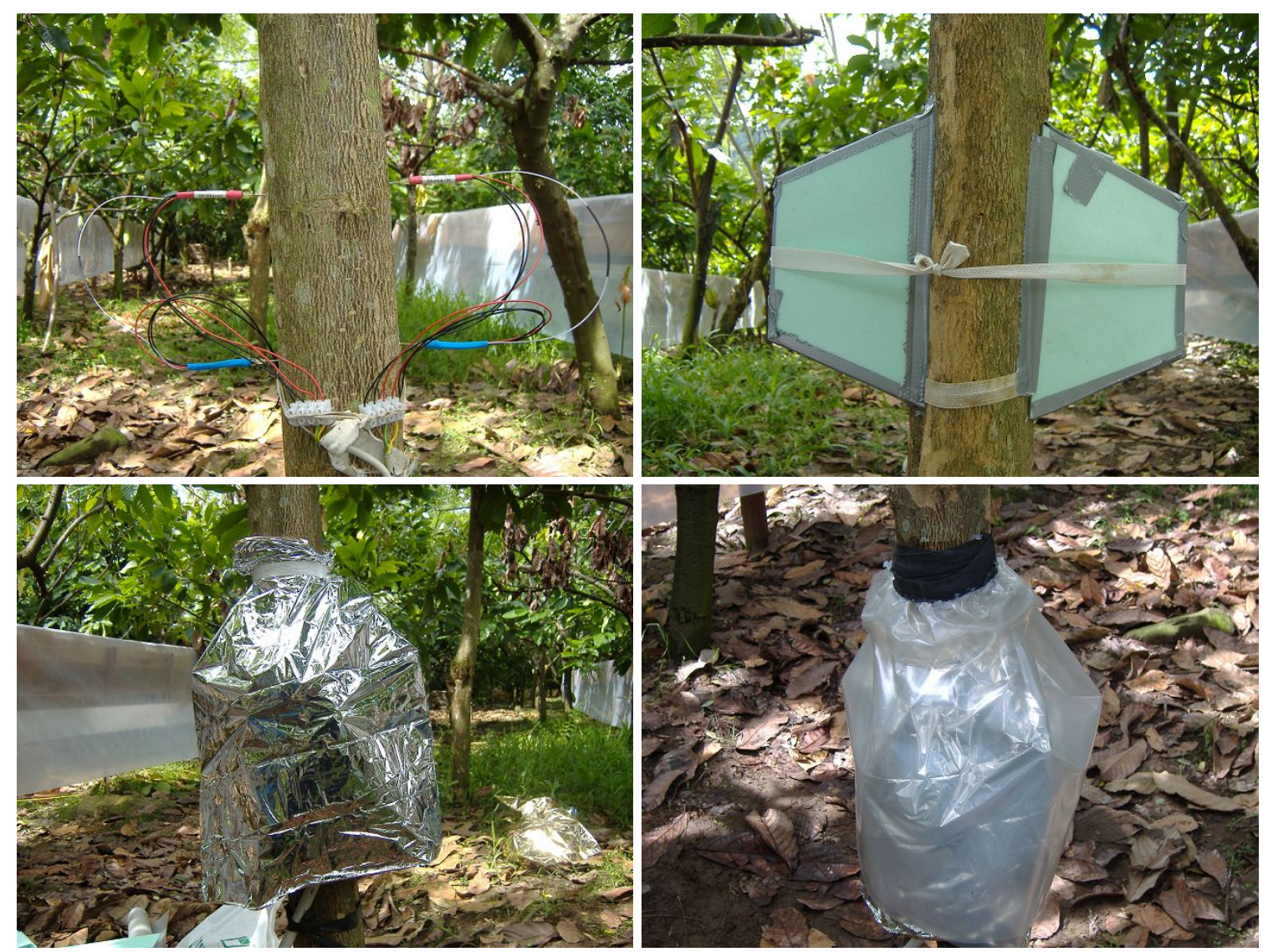

Figure 7: Installed sap flux sensor, shielding with Styrofoam, reflective foil and plastic.

In order to accurately calculate daily tree water use $\left(Q, \mathrm{Kg}_{\mathrm{day}}{ }^{-1}\right)$ from sap flux density and sapwood area, it is necessary to assess active sapwood depth and to account for radial variations of sap flux density within the active sap wood. Sap flux density usually declines with increasing xylem depth regardless of wood anatomy (Phillips et al., 1996). Sapwood depth was estimated by dye application to the whole radius of the tree via drill holes (e.g. Andrade et al., 1998; Meinzer et al., 2001). On bright days a small reservoir filled with the dye was glued to the stem of a sample tree. Following this application, a $2 \mathrm{~mm}$ wide hole was drilled in radial direction towards the center of a sample tree such that the drill was fully submerged in the dye. In this way, air did not enter the drill hole, but dye was taken up by the injured pores and transported in downstream direction. After 2-3 hours, a wood core was taken about $5 \mathrm{~cm}$ above the previous drill hole. The length of the colored section, measured to the nearest mm, was taken as sapwood depth. To assess sapwood activity with increasing depth, profiles of radial sap flux density were measured in up to 8 trees per species for approximately 10 days. In measuring these profiles, one sensor inside of the stem of sample trees remained at the reference depth (0 to $2.4 \mathrm{~mm}$ below the cambium), while the other was installed at increasing depth intervals $(2.4$ to $4.8 \mathrm{~cm}$ and 4.8 to $6.2 \mathrm{~cm}$ below the cambium), remaining for at least 3 days at each interval. Daily tree water use was cal- 
culated by summing water flow (flow $=$ flux $*$ area) in the ring-shaped stem cross sections bounded by the tip and the end of each probe (Edwards et al., 1996):

$$
Q=\sum_{i=1}^{i=n} Q_{i} \quad \text { with } \quad Q_{i}=\frac{J_{s c i} \times A_{i}}{1000}
$$

Where $Q\left(\mathrm{~kg} \mathrm{~d}^{-1}\right)$ is the water use per tree, $Q_{i}$ the water flow through sapwood $\operatorname{ring} i, J_{s i}(\mathrm{~g}$ $\left.\mathrm{cm}^{-2} \mathrm{~d}^{-1}\right)$ the cumulative daily sap flux density measured within each sapwood depth, and $A_{i}\left(\mathrm{~cm}^{2}\right)$ the ring-shaped area of sapwood bounded by the tip and the end of a probe for a given depth interval $i$.

Transpiration rates $\left(T_{\text {tree }}, \mathrm{mm} \mathrm{d}^{-1}\right)$ were derived for individual trees by dividing $Q$ by the crown projection area of the targeted tree. The stand transpiration rate $\left(T_{\text {stand }}, \mathrm{mm} \mathrm{d}^{-1}\right)$, expressed per unit ground area, was calculated following Garcia Santos (2007): we derived daily relationships between $\mathcal{Q}$ and tree diameters for each species, inserted the known diameters of all other individuals found in the plot into the respective equations, summed the calculated water use rates of all trees and divided the result by the area of the plot.

\subsubsection{Soil water content}

Volumetric soil water content was measured in the study site using time domain reflectrometry probes (TDR, CS616, Campbell Scientific Inc., Logan, UT) installed at a series of soil depths in close proximity $(\sim 2-5 \mathrm{~m})$ to studied trees. In the one large soil pit in each plot $(80 \times 160 \times$ $300 \mathrm{~cm}$ ), TDR sensors were placed at depths of 10, 20, 40, 75, 150 and $250 \mathrm{~cm}$. Additional sensors were installed at depths of 10, 40 and $75 \mathrm{~cm}$ in two smaller soil pits $(80 \times 100 \times 250 \mathrm{~m})$ in each plot. TDRs were placed at the end of horizontal holes dug into the vertical pit walls. These holes were then refilled with soil, and the pit walls were covered with plastic foil to prevent evaporation (Figure 8). It was at times necessary to deviate from the originally proposed field set up because some of the sensors broke down during the course of the experiment or gave erroneous readings. TDR installation was especially hindered by high rock fragment content at greater depths. For this reason, only two roof plots and two control plots carried TDRs at 150 $\mathrm{cm}$. Additionally, TDRs could only be installed at $250 \mathrm{~cm}$ in two control plots and one roof plot. 

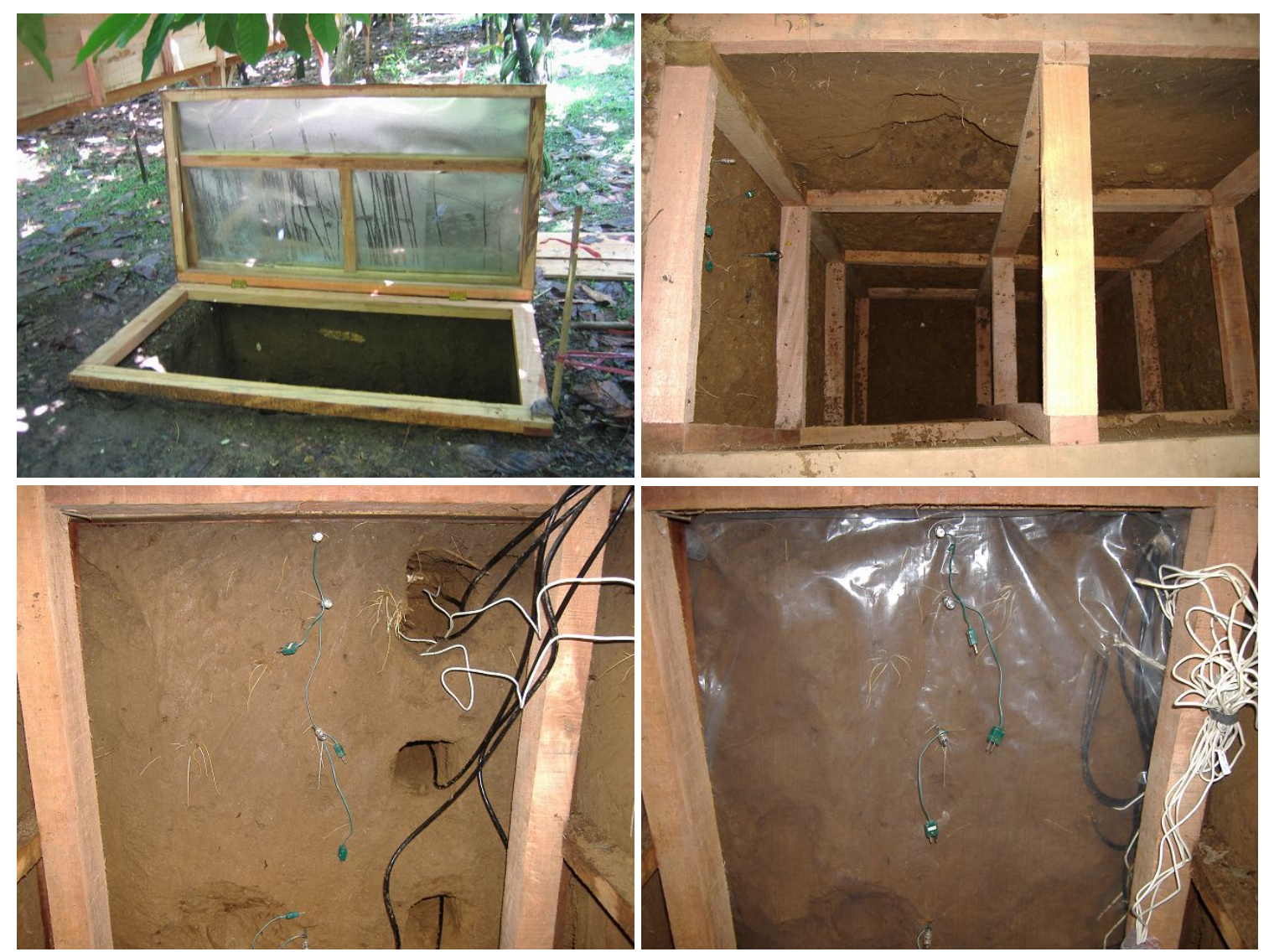

Figure 8: Soil pit lid (Picture by Oliver van Straaten), view into the pit, TDR installation into the pit walls and plastic covered pit wall. The black wires denote to TDR and the white and green ones to other installations

The probes were calibrated following Veldkamp and O’Brien (2000), using two samples each from depths of 10, 40 and $70 \mathrm{~cm}$. As there were minimal differences in calibration curves between depths, one lumped calibration was applied to TDRs at 10, 20, 40 and $75 \mathrm{~cm}$ depth. The calibration equation derived was:

$\theta=0.0003 \tau^{2}+0.0173 \tau-0.3494$

Where $\theta\left(\mathrm{m}^{3} \mathrm{~m}^{-3}\right)$ is the volumetric soil water content and $\tau(\mu \mathrm{s})$ is the output period of the TDR probe. At greater depths, calibration was not possible due to the high content of rock fragment previously mentioned. Since soil types seemed to be substantially different at all depths below $75 \mathrm{~cm}$, the manufacturer's calibration was applied here in substitution of the originally proposed calibration. Similar calibration procedures were carried out in Panama and the Philippines.

Care was taken to install the TDRs at a distance to rock fragments in order to avoid interference with the measurements. However, the prevalence of rock fragments therefore caused an overestimation of total soil water storage due to the fact that rock fragments have a much lower water storage capacity than soil. Despite the minimal porosity found in rock fragments $(<10 \%)$, 
it was assumed that rock fragments do not hold (plant available) water. To correct for the resulting overestimation of soil water storage, all measured volumetric water contents were proportionally reduced to the actual volume of soil that was not occupied by rock fragments.

Following Fiés et al. (2002), measured water content was corrected by:

$\theta=\left(1-\frac{V_{r}}{100}\right) \times \theta_{\text {soil }}$

Where $\theta$ is the corrected volumetric water content of the mixture of soil and rocks, $V_{r}$ is the percentage of total soil volume occupied by rocks and $\theta_{\text {soil }}$ is the water content originally measured in distance to rock fragments.

The total volume of rock fragments in the soil was estimated in soil layers of $50 \mathrm{~cm}$ depth down to $250 \mathrm{~cm}$ in one pit per plot. Rock fragments were excavated, cleaned, sun-dried and weighed. Rock volume was calculated from an estimate of rock bulk density derived from the weight and water displacement of a sub sample of rock fragments. The measured volumetric soil water contents at 10,20,40,75 cm and $250 \mathrm{~cm}$ depth were then corrected using the rock fragment contents from the respective layers. For the water content measured at $150 \mathrm{~cm}$ depth the average rock fraction of the 100-150 and 150-200 cm layers were utilized. The water contents given in Chapter 3 (Köhler et al., 2009) could not be corrected in this manner since data on rock fragment bulk density was not available by the time the paper was finished. However, no calculations of soil water storage, that would be substantially influenced by the absolute magnitude of soil water content, were carried out in the framework of this publication.

\subsection{Sap flux density model}

A sap flux density model was employed as a diagnostic tool to analyze the sap flux data sets from the study sites in Indonesia, Panama, and the Philippines. This allowed the huge datasets to be scaled down to a few easily comparable variables representing species specific sap flux patterns and sap flux response to environmental conditions. The model's form originates from a description of canopy conductance by Jarvis (1976), but it has been widely modified and adapted to describe stand transpiration or sap flux (e.G. Granier et al., 2000; Cienciala et al., 2000; Oren and Pataki, 2001; Harris et al., 2004; Whitley et al., 2008). The specific model used in the context of this work originates from Dierick and Hölscher (2009), whose model is a modification of that used by O'Brien et al. (2004). In this model, a constant factor $a$, corresponding to maximal sap flux density of a specific tree, is multiplied by two non linear response functions, each depending on a single environmental parameter. This allows the influence of each environmental parameter to be interpreted separately. Both response functions can take values between zero and one. For 
example, during the night when global radiation $\left(R_{g}\right)$ is zero, modeled sap flux is forced to be zero. $R_{g}$ and VPD were chosen as explanatory variables because analyses revealed that these parameters where highly correlated with sap flux densities. Soil water content exerted no influence on $J_{s}$ for trees in the experiments in Panama, the Philippines and Indonesia (before the onset of the throughfall reduction experiment). However, in the case of Indonesia, the model could also not be applied in the course of the throughfall reduction experiment because data on global radiation was lacking when soil water content became influential. The final form of the model was:

$J_{s \text { model }}=a \frac{R_{g}}{b+R_{g}} \times \frac{1}{1+e x p^{\frac{c-\mathrm{VPD}}{d}}}$

Modelled sap flux density $J_{s \text { model }}$ reaches a maximum value $a\left(\mathrm{~g} \mathrm{~cm}^{-2} \mathrm{~h}^{-1}\right)$ when all environmental conditions are optimal. Parameter $b\left(\mathrm{~J} \mathrm{~m}^{-2} \mathrm{~s}^{-1}\right.$, or $\mathrm{W} \mathrm{m}^{-2}$, note: $\left.1 \mathrm{~W}=1 \mathrm{~J} \mathrm{~s}^{-1}\right)$ can be interpreted as a measure of the light saturation level. Assuming VPD is non-limiting, sap flux density reaches just over $90 \%$ of the maximum sap flux density $a$ if radiation levels equal ten times parameter $b$. Parameter $c(\mathrm{kPa})$ equals the VPD for which $J_{s \text { model }}$ rises to half of the maximum value ( $\mathrm{R}_{g}$ non-limiting), whereby $d(\mathrm{kPa})$ is related to the slope - i.e. the increase in $J_{\text {s model }}$ for a given increase in VPD. Model parameters $a, b, c$ and $d$ in the response functions were estimated by minimizing the residual sum of squares using a Gauss-Newton algorithm.

\subsection{Soil water transport model}

\subsubsection{Theory}

In order to better understand the governing processes of soil water movement in the Indonesian throughfall reduction experiment and to assess differences in the soil water budget measured as differences in infiltration, drainage, soil moisture storage and root water uptake (transpiration) between roof plots and control plots, we applied the soil water transport model HYDRUS-1D (Šimůnek et al., 2008) which numerically solves the Richards equation (Richards, 1931) for variably-saturated water flow. The Richards equation is given by:

$$
\frac{\partial \theta}{\partial t}=\frac{\partial}{\partial x}\left[K\left(\frac{\partial h}{\partial x}+\cos a\right)\right]-S
$$

Where $b$ is the hydraulic head $(\mathrm{cm}), \theta$ is the volumetric water content $\left(\mathrm{cm}^{3} \mathrm{~cm}^{-3}\right), t$ is time (days), $x$ is the spatial coordinate ( $\mathrm{cm}$, positive upward), $S$ is the sink term $\left(\mathrm{cm}^{3} \mathrm{~cm}^{-3} \mathrm{day}^{-1}\right)$ accounting for root water uptake by plants, and $\alpha$ is the angle between the flow direction and the vertical axis. In our case $a=0$ because we deal only with vertical water flow here. $K$ is the unsaturated hydraulic conductivity function $\left(\mathrm{cm} \mathrm{day}^{-1}\right)$. The soil water retention, $\theta(h)$, and hydraulic 
conductivity, $K(b)$, functions are highly nonlinear functions of the hydraulic head (Šimůnek et al., 2008). HYDRUS-1D allows for the selection of five different analytical models to describe these functions. For this study the commonly used soil water retention function given by van Genuchten (1980) was selected:

$S_{e}(b)=\frac{\theta(b)-\theta_{r}}{\theta_{s}-\theta_{r}}=\left[1+a(b)^{n}\right]^{-m}$

Where $S_{e}\left(\mathrm{~cm}^{3} \mathrm{~cm}^{-3}\right)$ is the effective saturation, $\theta(b)\left(\mathrm{cm}^{3} \mathrm{~cm}^{-3}\right)$ is the volumetric soil water content at hydraulic head $h(\mathrm{~cm}), \theta_{s}$ and $\theta_{r}$ are saturated and residual water content $\left(\mathrm{cm}^{3} \mathrm{~cm}^{-3}\right), a$ $\left(\mathrm{cm}^{-1}\right)$ is the inverse of the air entry head, and $m$ and $n$ are dimensionless curve shape parameters $\left(\mathrm{m}=1-\mathrm{n}^{-1},(-)\right)$. The unsaturated hydraulic conductivity of the soil was described by Mualems' pore-size distribution model (Mualem, 1976):

$K\left(S_{e}\right)=K_{s a t} S_{e}^{\lambda}\left[1-\left(1-S_{e}^{1 / m}\right)^{m}\right]^{2}$

Where $K\left(S_{e}\right)$ and $K_{\text {sat }}$ are the unsaturated and saturated hydraulic conductivities $\left(\mathrm{cm} \mathrm{day}^{-1}\right)$, and $\lambda(-)$ is the tortuosity parameter.

\subsubsection{Model parameterization}

Vertical soil heterogeneity was modeled using five soil layers (of different materials) in a profile $250 \mathrm{~cm}$ deep (251 nodes) such that two layers adjoined at the mean distance between two TDRs. Lacking sufficient replications of soil water content measurements at $250 \mathrm{~cm}$ depth, we did not parameterize a sixth soil layer but rather extended the fifth layer toward $250 \mathrm{~cm}$. Observation nodes were set at the respective position of each TDR. Upper boundary conditions were set to 'atmospheric with surface run off,' meaning that water can infiltrate into the soil depending on the prevailing moisture conditions near the surface (Šimůnek et al., 2008). Any excess water will create surface run off. 'Free drainage' was used as lower boundary such that there is a flux out of the flow domain equal to the soils' hydraulic conductivity for a given pressure head at given time due to gravity. The solution of the Richards' equation requires knowledge of the initial water content prevalent at each node. These 'initial conditions' were provided by measured water contents. Time variable boundaries (input variables) were net precipitation $\left(P_{n e t}(\mathrm{~mm})\right)$ and measured stand transpiration. Evaporation from the bare soil was considered negligible because the soil was well covered with leaf-litter and little radiation reached the ground. Daily throughfall was calculated by applying a linear regression from weekly gross precipitation $\left(P_{\text {gross }}\right)$ and weekly measured throughfall (Moser, unpublished data) to daily precipitation data (Figure 9). 


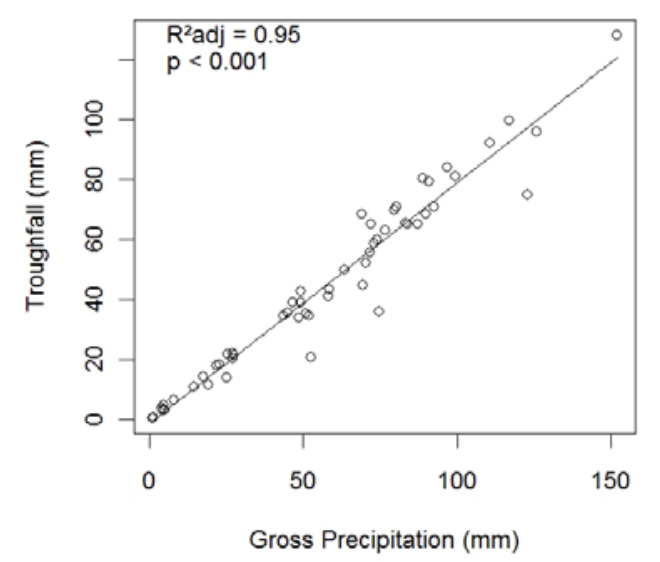

Figure 9: Weekly throughfall ( $\mathrm{mm}$ ) as function of weekly Gross Precipitation (mm), data from Moser (unpublished)

The fine root biomass of each species was measured in layers of $20 \mathrm{~cm}$ depth at approximately $1 \mathrm{~m}$ horizontal distance from the nearest tree (data from Moser et al., in press). Rooting patterns did not change significantly during the course of the experiment (Moser et al., in press). Fine root biomass declined exponentially with depth: $67 \%$ of the total biomass was located in the top $40 \mathrm{~cm}$ and zero was found at $240 \mathrm{~cm}$ (Schwendenmann et al., 2010). HYDRUS-1D only allows for input transpiration to be withdrawn from one root system. Therefore fine root biomass of both species was added together for each depth. The program then derived a normalized root biomass at each node by linear interpolation between depths. Figure 10 shows the normalized root distribution alongside the five different soil layers. 

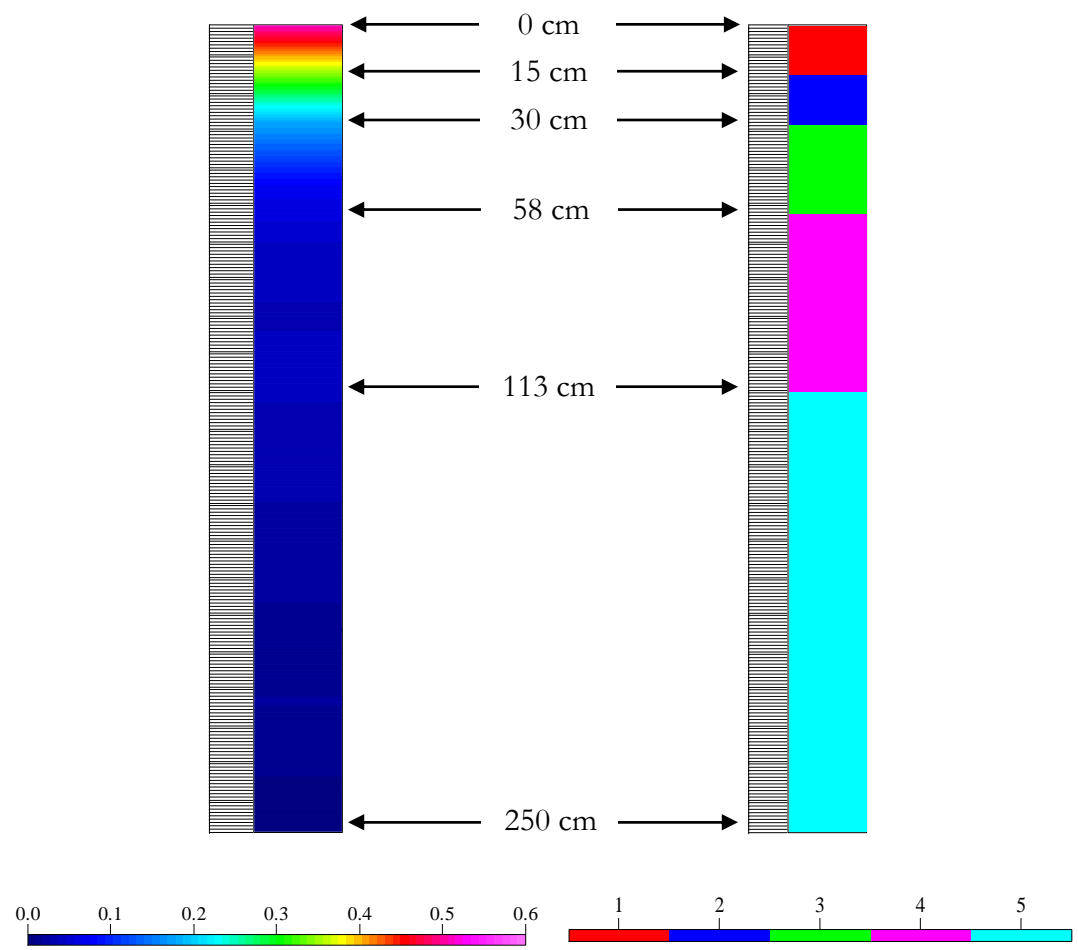

Root distribution (-)

Soil layers (-)

Figure 10: Graphical Interface of HYDRUS 1D with normalized fine root distribution and parameterized soil layers. Soil layers adjoin at the mean distance between two TDRs.

A simple S-shaped root water uptake stress response function was selected which reduces potential root water uptake (given by the variable boundary conditions) to the actual possible uptake for the given water potential (van Genuchten, 1987; van Genuchten and Gupta, 1993):

$$
\operatorname{ar}(h)=\frac{1}{\left[1+\left(\frac{h(z)}{h_{50}}\right)^{p}\right]}
$$

Where $\operatorname{ar}(-)$ is the water stress response $(0<a r<1)$ with which potential root water uptake (given by input transpiration) is multiplied, $h(\mathrm{z})(\mathrm{cm})$ is the soil water potential at location $z, h_{50}$ $(\mathrm{cm})$ is the soil water potential at which root water uptake rate is reduced by $50 \%$, and $p(-)$ is a fitting parameter.

Like Sommer et al. (2003), we used actual transpiration (derived from sap flux measurements) as input and thus had to match potential and actual root water uptake in order to meet the mass balance requirements which hold that measured (potential) and modeled (actual) transpiration must be of equal magnitude. Hence we set $h_{50}$ and $p$ to arbitrarily high values of -5000 $\mathrm{cm}$ and 6 to ensure that only very dry conditions could reduce potential root water uptake. The 
root adaptability factor (Šimůnek et al., 2008) was set to zero so that water uptake hindered by low water potential from one layer could be compensated for by increased uptake from another.

The model was not applied to describe soil water movement in individual plots due to the fact that $T$ and $P_{n e t}$ consisted of averages taken across all three roof plots and all three control plots.

\subsubsection{Adjustment of soil bydraulic parameters}

For the purpose of this study, the main points of interest are the quantification of the remaining components of the stand water budget, especially the calculation of timing and volume of drainage. To accurately monitor these variables it is necessary first to meet the mass balance requirements (see "Model parameterization") and second to match the measured soil water contents to modeled soil water contents. The hydraulic parameters of the van Genuchten function estimated from laboratory pressure plate measurements (van Straaten, unpublished data) were originally used to parameterize the model. However, primary model runs showed that these parameters were not suitable to describe the water movement processes observed in the field. The model was unstable and did not converge. It is a common occurrence that laboratory derived hydraulic parameters differ from field conditions (Rasmussen et al., 1993). Such differences arise from the high variability of soil pore systems in time and space and across a multitude of scales (Durner and Lipsius, 2005). In addition, the sampling procedure (Durner and Lipsius, 2005) and the measurement process itself (Ghezzehei and Or, 2003) can change the behavior of the system under consideration. Hysteresis may also play an important role in the observed differences because soil water retention functions are mostly established by drying soil samples, while wetting and drying events occur in the field (Belk et al., 2007). Thus, in order to model soil water flow, some adaptation of soil hydraulic parameters is often necessary to derive "effective" hydraulic parameters representative of the field conditions under consideration (Jhorar et al., 2004; Durner et al., 2008). For this reason many modeling studies iteratively adjust soil hydraulic parameters (e.g. Schlegel et al., 2004; Belk et al., 2007). It is also common to inversely adjust these parameters based on evapotranspiration fluxes and soil water contents and/or potentials measured under field conditions (e.g. Vrugt et al., 2001; Jhorar et. al., 2002; Ritter et al., 2003, Sommer et al., 2003). Both methods seek to minimize deviations between simulated and measured variables. However, manual adaptation of soil hydraulic parameters is considered somewhat 'non-scientific' (Ritter et al., 2003) so this study opted for an inverse adaptation of soil hydraulic parameters.

HYDRUS-1D implements a Marquardt-Levenberg type parameter estimation technique for the simultaneous fitting of 15 hydraulic parameters (three per layer). The pedotransfer function 
of the ROSETTA software (Schaap et al., 2001) was used to derive initial estimations of the soil hydraulic parameters $\left(\theta_{s}, \theta_{r}, a, n\right.$ and $\left.K_{s a t}\right)$ from soil texture and bulk density for each layer. We set $\lambda$ to -1 based on Schaap and Leij (2000) who reported an improved prediction of unsaturated hydraulic conductivity as compared to the originally suggested $\lambda=0.5$ (Mualem, 1976). In a sensitivity analysis based on the comparison of the root mean square errors (RMSE) of modeled and predicted water contents, we found $\theta_{s}, a$ and $n$ to have the largest impact on model fit. These were inversely optimized in this study, while $\theta_{r}$, and $K_{s a t}$ were taken from the ROSETTA prediction. Because observed water contents entered the objective function during optimization, model evaluation is not strictly independent (Sommer et al., 2003). Thus it was necessary to separate the measurement period into calibration and validation phases when evaluating the model's performance.

\section{References}

Andrade, J.L., Meinzer, F.C., Goldstein, G., Holbrook, N.M., Cavelier, J., Jackson, P., Silvera, K., 1998. Regulation of water flux through trunks, branches, and leaves in trees of a lowland tropical forest. Oecologia, 115, 463-471.

Belk, E. L., Markewitz, D., Rasmussen, T. C., Carvalho, E. J. M., Nepstad, D. C., Davidson, E. A., 2007. Modeling the effects of throughfall reduction on soil water content in a Brazilian Oxisol under a moist tropical forest. Water Resour. Res. 43, W08432.

Cienciala, E., Kucera, J., Malmer, A., 2000. Tree sap flow and stand transpiration of two Acacia mangium plantations in Sabah, Borneo. Journal of Hydrology, 236, 109-120.

Clearwater, M. J., Meinzer, F. C., Andrade, J. L., Goldstein, G., Holbrook, N. M., 1999. Potential errors in measurements of nonuniform sap flow using heat dissipation probes. Tree Physiology, 19, 681-687.

Dierick D., Hölscher D., 2009. Species-specific tree water use characteristics in reforestation stands in the Philippines. Agricultural and Forest Meteorology, 149, 1317-1326.

Dietz J, 2007. Rainfall partitioning in differently used montane rainforests of Central Sulawesi, Indonesia. Dissertation, Universität Göttingen, 103 pages.

Durner, W., Lipsius, K., 2005. Determining Soil Hydraulic Properties. In: Anderson M.G., McDonnell, J. J., Encyclopedia of Hydrological Sciences, Chapter 75, 1021-1144, John Wiley \& Sons, Ltd.

Durner, W., Jansen, U., Iden, S.D., 2008. Effective hydraulic properties of layered soils at the lysimeter scale determined by inverse modeling. European Journal of Soil Science, 59, 114-124.

Edwards, W. R. N., Becker, P., Cermák, J., 1996. A unified nomenclature for sap flow measurements. Tree Physiology $17: 65-67$.

FAO, 1998. Crop evapotranspiration - Guidelines for computing crop water requirements - FAO Irrigation and drainage paper 56, Food and Agriculture Organization of the United Nations, Rome.

Fiès, J. C., De Louvigny, N., Chanzy, A., 2002. The role of stones in soil water retention. European Journal of Soil Science 53, 95-104. 
Ghezzehei, T. A., Or, D., 2003. Stress-induced volume reduction of isolated pores in wet soil. Water Resources Research 39(3), 1067.

Granier, A., 1985. A new method of sap flow measurement in tree stems. Annals of Forest Science, 42, 193-200.

Granier, A., 1987. Evaluation of transpiration in a douglas-fir stand by means of sap flow measurements. Tree Physiology, 3, 309-319.

Granier, A., Bobay, V., Gash, J. H. C., Gelpe, J., Saugier, B., Shuttleworth, W. J., 1990. Vapour flux density and transpiration rate comparisons in a stand of maritime pine (Pinus pinaster Ait.) in Les Landes forest. Agricultural and Forest Meteorology, 51, 309-19.

Granier, A., Loustau, D., Bréda, N., 2000. A generic model of forest canopy conductance dependent on climate, soil water availability and leaf area index. Annals of Forest Science, 57, 755-765.

Harris, P. P., Huntingford, C., Cox, P. M., Gash, J. H. C., Malhi, Y., 2004. Effects of soil moisture on canopy conductance of Amazonian rainforest. Agri-cultural and Forest Meteorology 122: 215-227.

James, S. A., Clearwater, M. J., Meinzer, F. C., Goldstein, G., 2002. Heat dissipation sensors of variable length for the measurement of sap flow in trees with deep sapwood. Tree Physiology, 22, 277-283.

Jarvis, P. G., 1976. The interpretation of the variations in leaf water potential and stomatal conductance found in canopies in the field. Philosophical Transactions of the Royal Society of London: Series B Biological Sciences, 273, 593-610

Jhorar, R. K., Bastiaanssen, W. G. M., Feddes R. A., van Dam, J. C., 2002. Inversely estimating soil hydraulic functions using evapotranspiration fluxes. J. Hydrol. 258, 198-13.

Jhorar, R. K., van Dam, J. C., Bastiaanssen, W. G. M., Feddes, R. A., 2004. Calibration of effective soil hydraulic parameters of heterogeneous soil profiles, Journal of Hydrology, 285, 233-247.

Köhler, M., Dierick, D., Schwendenmann, L., Hölscher, D., 2009. Water use characteristics of cacao and Gliricidia trees in an agroforest in Central Sulawesi, Indonesia. Ecohydrology 2, 520-529.

Langenberger, G., 2006. Habitat distribution of dipterocarp species in the Leyte Cordillera: an indicator for speciessite suitability in local reforestation programs. Annals of Forest Science, 63, 149-156.

Lu, P., Müller, W. J., Chacko, E. K., 2000. Spatial variations in xylem sap flux density in the trunk of orchard-grown, mature mango trees under changing soil water conditions. Tree Physiology, 20, 683-692.

Lu, P., Urban, L., Zhao, P., 2004. Granier's thermal dissipative probe (TDP) method for measuring sapflow in trees: theory and practice. Acta Bot. Sin. 46 (6), 631-646.

Meinzer, F.C., Goldstein, G., Andrade, J.L., 2001. Regulation of water flux through tropical forest canopy trees: Do universal rules apply? Tree Physiology $21: 19-26$.

Moser, G., Leuschner, C., Hertel. D., Hölscher, D., Köhler, M., Leitner, D., Michalzik, B., Prihastanti, E., Tjitrosemito, S., Schwendenmann, L., The drought response of cacao trees (Theobroma cacao) in a replicated 13months desiccation experiment (C. Sulawesi, Indonesia). accepted for publication in Agroforestry systems.

Mualem, Y., 1976. A new model for predicting the hydraulic conductivity of unsaturated porous media. Water Resour Res 12, 513-522.

O'Brien, J. J., Oberbauer, S. F., Clark, D. B., 2004. Whole tree xylem sap flow responses to multiple environmental variables in a wet tropical forest. Plant, Cell and Environment, 27, 551-567. 
Oren, R., Phillips, N., Ewers, B. E., Pataki, D. E., Megonigal, J. P., 1999. Sap-flux-scaled transpiration responses to light, vapor pressure deficit, and leaf area reduction in a flooded Taxodium distichum forest. Tree Physiology, 19, 337-347.

PAGASA, 2007. Philippine Atmospheric, Geophysical and Astronomical Services Administration, Philippines, available from http://www.pagasa.dost.gov.ph (last visited: 20/08/2009).

Phillips, N, Oren R, and Zimmermann R., 1996., Radial patterns of xylem sap flow in non-, diffuse- and ring-porous tree species. Plant Cell Environment 19 : 983-990.

Rasmussen, T. C., Evans, D. D., Sheets, P. J., Blanford, J. H., 1993. Permeability of Apache Leap Tuff: Borehole and core measurements using water and air. Water Resour. Res. 29(7), 1997-2006.

Richards, L. A., 1931. Capillary conduction of liquids through porous mediums. Physics, 1 (5), 318-333.

Ritter, A., Hupet, F., Munoz-Carpena, R., Lambot, S., Vanclooster, M., 2003. Using inverse methods for estimating soil hydraulic properties from field data as an alternative to direct methods. Agric. Water Management 59, 77-96.

Schaap, M. G., Leij, F. J., 2000. Improved prediction of unsaturated hydraulic conductivity with the Mualem-van Genuchten model. Soil Sci. Soc. Am. J. 64, 843-851.

Schaap, M. G., Leij, F. J., van Genuchten, M. T., 2001. ROSETTA: a computer program for estimating soil hydraulic parameters with hierarchical pedotransfer functions. J. Hydrol. 251, 163-176.

Šimůnek, J., Šejna, M., Saito, H., Sakai, M., van Genuchten, M. T., 2008. The HYDRUS-1D software package for Simulating the One-Dimensional Movement of Water, Heat, and multiple solutes in variably-saturated media. Department of environmental sciences University of California Riverside, Riverside, California, USA, Version 4.0.

Schlegel, P., Huwe, B., Teixeira, W. G., 2004. Modelling species and spacing effects on root zone water dynamics using Hydrus-2D in an Amazonian agroforestry system. Agroforestry Systems 60, 277-289.

Sommer, R., Fölster, H., Vielhauer, K., Maklouf Carfvalho, E. J., Vlek, P. L. G., 2003. Deep Soil Water Dynamics and Depletion by Secondary Vegetation in the Eastern Amazon. Soil Sci. Soc. Am. J. 67, 1672-1686.

Schwendenmann, L., Veldkamp, E., Moser, G., Hölscher, D., Köhler, M., Clough,Y., Anas, I., Djajakirana, G., Erasmi, S., Hertel, D., Leitner, D., Leuschner, C., Michalzik, B., Propastin, P., Tjoa, A., Tscharntke, T., van Straaten, O., 2010. Effects of an experimental drought on the functioning of a cacao agroforestry system, Sulawesi, Indonesia. Global Change Biology 16, 1515-1530.

van Genuchten, M. T., 1980. A closed-form equation for predicting the hydraulic conductivity of unsaturated soils. Soil Sci. Soc. Am. J. 44, 892-898.

van Genuchten, M. T., 1987. A numerical model for water and solute movement in and below the root zone. Res. Rep. 121, U.S. Salinity Lab., Agric. Res. Serv., U.S. Dep. of Agric., Riverside, California.

van Genuchten, M. T., Gupta, S. K., 1993. A reassessment of the crop tolerance response function. Bull. Indian Soc. Soil Sci. 4, 730-737.

Veldkamp, E., O’Brien, J. J., 2000. Calibration of a frequency domain reflectrometry sensor for humid tropical soils of volcanic origin. Soil Sci. Soc. Am. J. 64, 1549-1553.

Vrugt, J. A., van Wijk, M. T., Hopmans, J. W., Šimůnek, J., 2001. One, wo, and three-dimensional root water uptake functions for transient modelling. Water Resour. Res. 37, 2457-2470.

Whitley, R., Zeppel, M., Armstrong, N., Mcinnis-Ng, C., Yunusa, I., Eamus, D., 2008. A modified Jarvis- Stewart model for predicting stand-scale transpiration of an Australian native forest. Plant and Soil, 305, 35-47. 


\title{
Water use characteristics of cacao and Gliricidia trees in an agro- forest in Central Sulawesi, Indonesia
}

\author{
Michael Köhler, Diego Dierick*, Luitgard Schwendenmann \& Dirk Hölscher \\ Tropical Silviculture and Forest Ecology, Burckhardt Institute, Georg-August-Universität Göttingen, Büsgenweg 1, 37077 \\ Göttingen, Germany
}

\begin{abstract}
Water use characteristics of cacao (Theobroma cacao) and Gliricidia sepium shade trees were studied in an agroforest on Sulawesi, Indonesia. The objectives were: (1) to identify environmental and tree structural factors controlling water use, (2) to analyze the effect of shade tree cover on cacao water use, and (3) to estimate stand level transpiration. Sap flux density was measured in up to 18 trees per species and described with a Jarvis-type model. Model parameters suggested a 49\% higher maximum sap flux density in cacao than in Gliricidia and species differences in the response to vapour pressure deficit and radiation. Tree water use was positively related to tree diameter in both species, but this relationship tended to differ between species. In cacao trees maximal tree water use increased with decreasing canopy gap fraction above the trees $\left(\mathrm{R}^{2}\right.$ adj $\left.=0.39, \mathrm{p}=0.04\right)$. This was paralleled by an increase of cacao stem diameter and leaf area with decreasing gap fraction. Maximum water use rate per unit crown area of cacao was $13 \%$ higher than that of Gliricidia. At the stand level the average transpiration rate was estimated at 1.5 $\mathrm{mm} \mathrm{d}^{-1}$ per unit ground area, $70 \%$ of which was contributed to by cacao. We conclude that, in the given stand, species differed substantially in water use characteristics, while estimated stand transpiration is in line with findings from other studies for cacao stands. Shade trees may enhance stand transpiration through own water use and additionally by increasing water use rates of cacao trees.
\end{abstract}

Keywords: transpiration, sap flux density, Theobroma cacao, Gliricidia Sepium, shade trees, gap fraction

Received 6 February 2009, Accepted 7 May 2009

* Corresponding author. Tel.: +49 551 399556; Fax: +49 551 394019; E-mail address: ddieric@gwdg.de 


\section{Introduction}

Cacao (Theobroma cacao L.) is one of the most important perennial cash crops world-wide and is cultivated in many tropical regions. Cacao, being originally an understorey tree of rainforests in tropical America, is traditionally cultivated below the canopy of shade trees. Shade trees may originate from natural forest, secondary forest or may be planted at stand establishment. If shade trees are being planted as e.g. done on already deforested land, often fast growing potentially nitrogen fixing trees such as Gliricidia spp. and Erythrina spp. are chosen. Currently, there is a tendency to remove shade trees a few years after establishment, which may give higher cacao yields at least on a short term basis (Steffan-Dewenter et al., 2007).

However, a physiological production model (Zuidema et al., 2005) did not reveal a strong influence of moderate shading on cacao yield. Only when shade trees intercepted more than $60 \%$ of available light, a decrease in cacao yield by more than $30 \%$ was predicted. Model outcome rather suggested strong influences of radiation and rainfall during dry periods. The simulated drought related yield reduction was up to 50\% (compared to potential yield) under low rainfall and adverse soil conditions. Shade trees can probably mitigate negative effects of droughts and low rainfall as shade reduces evaporative demand of cacao trees and may thereby reduce stress of cacao plants. On the other hand, shade trees may reduce the water available for cacao trees as shade trees in cacao cultivation enhance rainfall interception loss and thus increase stand evaporation (Dietz et al., 2006; Poppenborg and Hölscher, in press). Also, shade trees can increase stand transpiration through their own water use, as well as by enhancing transpiration rates of associated cacao trees. For coffee in Costa Rica, the estimated stand level transpiration of coffee grown with shade trees was on average twice as high as that of coffee grown without shade trees (van Kanten and Vaast, 2006). Coffee plants even showed higher transpiration rates underneath a shade tree canopy than grown in full sun, which was explained by an enhanced vegetative growth of coffee under shade (van Kanten and Vaast, 2006). Also for cacao trees in Ghana it was observed that biomass was higher under shade trees and in a given stand biomass increased with proximity to shade trees (Isaac et al., 2007).

Stand level evapotranspiration by a cacao plantation ( $>98 \%$ cacao trees) in Central Sulawesi, Indonesia, was $2.6 \mathrm{~mm} \mathrm{~d}^{-1}$ as derived from eddy covariance measurements (Falk, 2004). Comparing the cacao plantation with natural forest suggested that a much smaller fraction of the available energy was used for evapotranspiration. In a model based study for cacao with different shade tree species in Costa Rica (Imbach et al., 1989), evapotranspiration was of similar magnitude as for cacao on Sulawesi. To our knowledge only one study determined transpiration rates 
for cacao stands based on sap flux measurements (Colas et al., 1999). This study found comparatively low transpiration rates of cacao stands and little to no effect of the presence of a coconut palm overstorey.

The present study was conducted in an upland region of Central Sulawesi, Indonesia, which is the third largest country with respect to cacao bean production (FAO, 2009). We studied a 6year-old cacao stand with Gliricidium sepium (Jacq.) Kunth ex Steud. shade trees. The stand can be considered young compared to the productive life span of cacao which may last 50 years, with highest yields being achieved at 25 to 30 years of age (Montgomery, 1981 as cited in Olaiya et al., 2006). In this stand we applied xylem sap flux techniques to measure water use at the tree level. The objectives were: (1) to identify environmental and tree structural factors controlling water use in the two species, (2) to analyze the effect of shade tree canopy cover on cacao water use, and (3) to estimate stand level transpiration.

\section{Methods}

\subsection{Study site}

The study was conducted in the margin zone of the Lore Lindu National Park in Central Sulawesi, Indonesia, in the vicinity of the village of Marena $\left(1.552^{\circ} \mathrm{S}, 120.020^{\circ} \mathrm{E}\right)$. Data from a nearby climate station (Gimpu, $5 \mathrm{~km}$ south of Marena at $471 \mathrm{~m}$ a.s.l.) collected between 2002 and 2006 showed an average annual temperature of $25.5^{\circ} \mathrm{C}$ and an annual precipitation of $2092 \mathrm{~mm}$ $\mathrm{y}^{-1}$ (Kreilein, unpublished data). The soil type at the study site was described as a sandy-loam Cambisol (Leitner unpublished data). The studied agroforest is located at $560 \mathrm{~m}$ a.s.l. on a mild slope (8-12 inclination) about $30 \mathrm{~m}$ above the water level of a nearby river. Cacao grows under a cover of Gliricidia sepium trees, which originate from cuttings. The stand had a mean stem density of 1030 cacao and 325 Gliricidia stems ha ${ }^{-1}$ and covered a total area of $8400 \mathrm{~m}^{2}$. Some coconut trees occurred scattered on the site $\left(23 \mathrm{stems} \mathrm{ha}^{-1}\right)$. The leaf area index of the stand was $5.3 \mathrm{~m}^{2} \mathrm{~m}$ 2. Leaf area index for the cacao tree layer was estimated at $3.8 \mathrm{~m}^{2} \mathrm{~m}^{-2}$ and for the shade trees in the stand at $1.3 \mathrm{~m}^{2} \mathrm{~m}^{-2}$ (Propastin and Erasmi, unpublished data). During the study period, pruning of cacao trees was carried out in July and December 2007. Gliricidia trees have not been pruned during the study period. No other agricultural operations but harvesting the cacao pods every two weeks and manual weeding were conducted. 


\subsection{Micrometeorological and soil moisture measurements}

Data on air humidity and air temperature (CS215), global radiation (CS300, Apogee Instruments Inc., Logan, UT, USA) and rainfall (ARG100, Environmental Measurements Ltd., Sunderland, UK) were gathered at a distance of $30 \mathrm{~m}$ from the study stand in an area where shade trees were absent at a height of $2 \mathrm{~m}$ above the canopy of cacao trees. Data were measured every 5 seconds, averaged and logged in 30 min intervals using a CR800 data logger. Measured global radiation values indicated that the global radiation sensor underestimated real values from October 2007 onwards because of sensor malfunctioning. Based on reference measurements made with two other sensors in June 2008 a correction factor was determined and applied to the data from October 2007 onwards. Therefore, data obtained after October 2007 on global radiation should be taken with caution. At the study site, volumetric soil water content was continuously measured with time domain reflectometry probes (CS616). We installed 8 and 6 probes at 10 and 75 $\mathrm{cm}$ depth respectively in 8 soil pits in proximity to the trees studied. Two soil pits could not be equipped with probes at $75 \mathrm{~cm}$ due to high stone content. Data were logged hourly with a CR1000 logger. The probes were calibrated for the local soil following the procedure described in Veldkamp and O'Brien (2000).

The calibration equation derived was:

$\theta=0.0003 \tau^{2}+0.0173 \tau-0.3494$

Where $\theta\left(\mathrm{cm}^{3} \mathrm{~cm}^{-3}\right)$ is the fractional volumetric soil water content and $\tau(\mu \mathrm{s})$ is the output period of the TDR probe. Unless otherwise stated, equipment originated from Campbell Scientific Inc., Logan, UT, USA.

\subsection{Sap flux measurements}

Sap flux density was measured with thermal dissipation sensors constructed after Granier (1987). A sensor consisted of a pair of probes with a diameter of $1.5 \mathrm{~mm}$ and a length of $24 \mathrm{~mm}$. The probes were inserted in tightly fitting aluminium tubes after heat conductive paste was applied to the probe. These were then inserted into predrilled holes in the outermost xylem spaced on average $14 \mathrm{~cm}$ apart in vertical direction. In cacao the vertical spacing varied at times slightly because of the rough architecture of the cacao bark which was covered with wounds, flowers and old pod peduncles. Two thermal dissipation sensors were installed per tree at the north and south side of the trunk at $130 \mathrm{~cm}$ height above the ground in Gliricidia. In cacao the sensors needed to be installed below the branching point (jorquette) which was located around 60 to 100 $\mathrm{cm}$ above the ground. Sensors were shielded by a box made from insulating Styrofoam and a sec- 
tion of the stem, extending well above and below the installation point, was covered in reflective foil and plastic foil. This protected sensors against damage, prevented rainwater entering the setup and limited temperature gradients caused by incident solar radiation heating the trunk.

The upper probe of each sensor was heated with a constant power of $250 \mathrm{~mW}$. Temperature difference between the two probes of each sensor was measured every 30 seconds, averaged and stored every $30 \mathrm{~min}$ (CR1000 data logger and AM 16/32 multiplexer, Campbell Scientific Inc., Logan, UT, USA.). The temperature difference was converted to sap flux density $\left(J_{s}\right.$ in $\left.\mathrm{g} \mathrm{cm}^{-2} \mathrm{~h}^{-1}\right)$ according to an empirically derived equation of Granier (1987).

Sap flux density was measured continuously for a 13 month period from February $1^{\text {st }} 2007$ to February $29^{\text {th }}$ 2008. If sap flux data for single trees was incomplete during a day due to power outage or maintenance the specific tree did not enter the calculations on the respective day. If more than 3 trees per species were not available we did not include the whole day in our species comparison and the calculation of monthly averages (see Table 4 for the number of days entering the calculations per month).

During the first month of the study 18 individuals were available per species. Structural characteristics of the trees studied are shown in Table 1. Presented relationships between tree water use and tree structural characteristics as well as application of the sap flux model were based on data collected in February 2007. This way we could make use of the 18 replicates. From March 2007 onwards half of the individuals were subjected to drought treatments (Schwendenmann et al., 2010). The data presented on water use characteristics over the entire study period were based on the 9 individuals per species growing under ambient conditions.

Table 1: Structural characteristics of the trees studied (mean and standard deviation, $\mathrm{n}=18$ ).

\begin{tabular}{|c|c|c|c|c|c|c|c|c|c|c|}
\hline \multirow[t]{2}{*}{ Species } & \multicolumn{2}{|c|}{$\begin{array}{c}\text { Diameter } \\
(\mathrm{cm})\end{array}$} & \multicolumn{2}{|c|}{$\begin{array}{c}\text { Height } \\
\text { (m) }\end{array}$} & \multicolumn{2}{|c|}{$\begin{array}{c}\text { Projected } \\
\text { crown area } \\
\left(\mathrm{m}^{2}\right)\end{array}$} & \multicolumn{2}{|c|}{$\begin{array}{c}\text { Leaf area } \\
\left(\mathrm{m}^{2}\right)\end{array}$} & \multicolumn{2}{|c|}{$\begin{array}{c}\text { Sapwood } \\
\text { area } \\
\left(\mathrm{cm}^{2}\right)\end{array}$} \\
\hline & Mean & $\mathrm{Sd}$ & Mean & $\mathrm{Sd}$ & Mean & $\mathrm{Sd}$ & Mean & $\mathrm{Sd}$ & Mean & $\mathrm{Sd}$ \\
\hline Theobroma cacao & 10.1 & 1.6 & 4.5 & 0.8 & 20.2 & 8.5 & 34.3 & 14.2 & 68.1 & 22.9 \\
\hline Gliricidia sepium & 15.0 & 2.5 & 10.9 & 2.1 & 40.4 & 27.5 & 57.3 & 29.7 & 95.5 & 11.4 \\
\hline
\end{tabular}

\subsection{Sap flux model}

The species-specific response towards driving forces of sap flux was described using a sap flux model in analogy to the work of O'Brien et al. (2004). In this way the extensive dataset was condensed to a set of few parameters which allowed a straightforward comparison between species. The model was not used to make any predictions of sap flux densities. Preliminary correlation analyses revealed that $J_{s}$ was highly correlated to $R_{g}$ and VPD, but not to soil moisture 
which was therefore omitted from the model. The specific model form used is a modification of the Jarvis-model (Jarvis, 1976) and has also been used by Dierick and Hölscher (2009). This model explains sap flux density $J_{s}\left(\mathrm{~g} \mathrm{~cm}^{-2} \mathrm{~h}^{-1}\right)$ by global radiation $\mathrm{R}_{g}\left(\mathrm{~J} \mathrm{~m}^{-2} \mathrm{~s}^{-1}\right)$ and vapour pressure deficit VPD $(\mathrm{kPa})$ :

$$
J_{s \text { model }}=a \times \frac{\mathrm{R}_{g}}{b+\mathrm{R}_{g}} \times \frac{1}{1+\exp \frac{c-\mathrm{VPD}}{d}}
$$

Modelled sap flux density $J_{s \text { model }}$ reaches a maximum value $a\left(\mathrm{~g} \mathrm{~cm}^{-2} \mathrm{~h}^{-1}\right)$ when all environmental conditions are optimal. Parameter $b\left(\mathrm{~J} \mathrm{~m}^{-2} \mathrm{~s}^{-1}\right)$ can be interpreted as a measure of the light saturation level. Assuming VPD is non-limiting, sap flux density reaches just over $90 \%$ of the maximum sap flux density $a$ if radiation levels equal ten times parameter $b$. Parameter $c(\mathrm{kPa})$ equals the vapour pressure deficit for which $J_{s \text { model }}$ rises to half of the maximum value $\left(R_{g}\right.$ nonlimiting), whereas $d(\mathrm{kPa})$ is related to the slope i.e. the increase in $J_{s \text { model }}$ for a given increase in VPD. Model parameters $a, b, c$ and $d$ in the response functions were estimated by minimizing the residual sum of squares using a Gauss-Newton algorithm.

\subsection{Sapwood area and tree water use}

The estimation of water use $(Q)$ for individual trees was based upon the sapwood area of the tree and the radial changes in $J_{s}$ present in the sapwood. We used two approaches to estimate both the extent and the activity of conducting sapwood in the trunk cross-section. Sapwood depth was determined for trees in the same stand by means of a dye staining experiment. Seven cacao and 14 Gliricidia trees, different from the trees used for sap flux measurement, were selected and sapwood depth was estimated at the respective installation height of the Granier sap flux sensors. It was decided to use a larger sample for Gliricidia because trees were more variable in shape and size than cacao. At noon on a bright day a $2.3 \mathrm{~mm}$ hole was drilled towards the centre of the stem of each tree and an Indigocarmin solution was injected into the drill hole. Three hours later a wood core was taken $50 \mathrm{~mm}$ above the injection point using an increment borer. The length of the coloured section of the wood core was measured to the nearest millimetre and taken as an estimate of sapwood depth (Andrade et al., 1998; Meinzer et al., 2001).

To assess sapwood activity with increasing depth under the cambium, profiles of radial sap flux density were measured in 8 trees per species for 10 days. These trees were mostly individuals that were also being used in the long term sap flux measurements. We employed again two sensors per tree, one of which remained at a depth of 0-24 $\mathrm{mm}$ below the cambium (reference depth) and the other was installed at the opposite side of the stem at $24-48 \mathrm{~mm}$ ( $2^{\text {nd }}$ depth) below 
cambium. When measuring radial profiles it was necessary to select trees with a sufficiently large diameter to avoid that the two sensors would influence each other by heat conduction. Other studies (e.g. Delzon et al., 2004) overcame this problem by placing the two sensors at a sufficient axial distance to each other. Since the cacao trees had a very low branching point and many of the Gliricidia trees showed disturbances in the lower parts of the trunk due to former management practices we could not opt for this method. A deeper installation at $48-72 \mathrm{~mm}\left(3^{\text {rd }}\right.$ depth) was not applicable since the installation depth would exceed the radius of most of the cacao trees. In large Gliricidia trees sensors installed at this depth would be in close proximity and potentially influence each other. In addition the staining experiment revealed heartwood formation at limited depth in large Gliricidia trees (see result section). To our knowledge there is no information available in literature on radial profiles of sap flux density for the species studied.

Upscaling from a point measurement (sensor) to tree level water use was done by summing water flow in a number of ring-shaped stem cross sections (Edwards et al., 1996):

$$
Q=\sum_{i=1}^{i=n} Q_{i} \quad \text { with } \quad Q_{i}=\frac{J_{s i} \times A_{i}}{1000}
$$

Where $\mathcal{Q}\left(\mathrm{kg} \mathrm{d}^{-1}\right)$ is the water use per tree, $Q_{i}$ is the water flow through ring $i, J_{s i}\left(\mathrm{~g} \mathrm{~cm}^{-2} \mathrm{~d}^{-1}\right)$ is the daily integrated sap flux density and $A_{i}\left(\mathrm{~cm}^{2}\right)$ is the ring-shaped area of sapwood that extents between the tip and the end of each probe for a given depth interval $i$. Thus we have an outer (reference depth) and an inner ring-shaped area ( $2^{\text {nd }}$ depth). Except for large Gliricidia trees (diameter $>12 \mathrm{~cm}$ ), the stem cross section consisted mainly out of sapwood. Radial profiles of sap flux density usually show a declining or a Gaussian shape with depth regardless of wood anatomy (Phillips et al., 1996). Therefore, if sapwood extended beyond the probe tip of the deepest sensor we approximated the remaining part of the profile assuming that the sap flux density declined linearly from the tip of the deepest probe to zero at the depth where heartwood formation was expected. In large Gliricidia trees where sapwood was about $25 \mathrm{~mm}$ deep and extended just beyond the sensor, tree water use was determined assuming a uniform sap flux density in the sapwood. With no additional data on the sap flux density profile available, this assumption seems reasonable. Moreover, sap flux sensors are expected to integrate flux differences over their length (Granier et al., 1994; but see Clearwater et al., 1999).

Water use rates of individual trees $\left(\mathrm{kg} \mathrm{d}^{-1}\right)$ were also expressed per unit crown projection area of that tree to yield tree level transpiration rates $\left(T_{\text {tree }}, \mathrm{mm} \mathrm{d}^{-1}\right)$. The stand transpiration rate $\left(T_{\text {stand, }}\right.$, $\mathrm{mm} \mathrm{d}^{-1}$ ) expressed per unit ground area was calculated following Garcia Santos (2007): We derived daily relationships between measured tree water use rates and tree diameters for both spe- 
cies, inserted the known diameters of all other individuals of the plot into the respective equations, summed the calculated water use rates of all trees and divided the result by the area of the plot.

\subsection{Tree dimension, leaf area and gap size above cacao trees}

For trees where sap flux was determined, tree diameter was measured between upper and lower probes of the sap flux sensor (60-130 cm above ground) with a tape measure. Tree diameter for other trees on the study site was measured at $80 \mathrm{~cm}$ height for cacao (low jorquette) and at $130 \mathrm{~cm}$ height for Gliricidia. Tree height was measured for the studied trees by means of a measuring stake. Additional data was collected for trees in which sap flux density was studied in the period from October 2007 to mid December 2007. Crown projection area of trees was estimated by measuring the distance from the stem to the edge of the crown in eight cardinal directions. The crown projection area of a tree was calculated as the sum of eight triangles centred around the stem. Tree leaf area $\left(\mathrm{m}^{2}\right)$ was estimated for cacao trees in which sap flux density was measured. To do so the number of leaves of each tree was counted and multiplied with the average area per leaf determined from 50 randomly sampled leaves. Also the gap fraction above studied cacao trees was determined. Hemispherical photographs were taken vertically upward above each of the 9 study trees with a high resolution digital camera (Coolpix S3 and EC-F8 fisheye lens, Nikon Coop. Tokyo, Japan). The camera was placed in a levelling device (Regent Instruments Inc., Saint-Foy, QC, Canada) which in turn was mounted on top of a telescopic tripod. Images were analysed for gap fraction within an angle of $10^{\circ}$ from zenith with CanEye 5.0 (INRA, 2007).

\subsection{Statistical analyses}

The relationships between sap flux density and environmental variables $\left(R_{g}\right.$ and VPD) and between water use and tree structural parameters were tested with linear regressions. The response of sap flux density to changes in environmental parameters was evaluated with the above mentioned non-linear model. In analogy to linear models we calculated an adjusted $\mathrm{R}^{2}$ for this non-linear model. Additionally root mean square error (RMSE) is given to judge model performance. Species differences in estimated model parameters, sap flux and water use were evaluated using a two sided Welch's t-test with a level of significance of $\mathrm{p} \leq 0.05$. The statistical analyses were conducted with R version 2.8.0 (R Development Core Team, 2008) 


\section{Results}

\subsection{Micrometeorological and soil moisture measurements}

Rainfall during the first 12 months of the study equalled $2937 \mathrm{~mm}$. All months received over $100 \mathrm{~mm}$ of rain except for January 2008 where rainfall was only $44 \mathrm{~mm}$ (Table 2). The average volumetric soil water content ranged from 0.38 to $0.45 \mathrm{~m}^{3} \mathrm{~m}^{-3}$ depending on depth and time of observation. Average daily air temperature was between 23.5 and $25.1^{\circ} \mathrm{C}$ and the average daily vapour pressure deficit (VPD) ranged from 0.6 to $0.8 \mathrm{kPa}$ (day- and nighttimes were not considered separately). Integrated daily global radiation $\left(R_{g}\right)$ varied from 15.8 to $20.4 \mathrm{MJ} \mathrm{m}^{-2} \mathrm{~d}^{-1}$.

Table 2: Monthly rainfall, meteorological conditions and volumetric soil water content (means and standard deviations) as measured during the study period.

\begin{tabular}{|c|c|c|c|c|c|c|c|c|c|c|c|c|}
\hline \multirow[t]{2}{*}{ Month } & \multirow[t]{2}{*}{$\begin{array}{l}\text { Days } \\
\text { (n) }\end{array}$} & \multirow[t]{2}{*}{$\begin{array}{c}\text { Cumulated } \\
\text { rainfall } \\
(\mathrm{mm})\end{array}$} & \multicolumn{2}{|c|}{$\begin{array}{c}\text { Daysum } \\
R_{g} \\
\left(\mathrm{MJ} \mathrm{m}^{-2} \mathrm{~d}^{-1}\right) \\
\end{array}$} & \multicolumn{2}{|c|}{$\begin{array}{c}\text { Mean daily } \\
\text { VPD } \\
(\mathrm{kPa}) \\
\end{array}$} & \multicolumn{2}{|c|}{$\begin{array}{c}\text { Mean daily air } \\
\text { temperature } \\
\left({ }^{\circ} \mathrm{C}\right) \\
\end{array}$} & \multicolumn{2}{|c|}{$\begin{array}{c}\theta \\
10 \mathrm{~cm} \\
\left(\mathrm{~m}^{3} \mathrm{~m}^{-3}\right) \\
\end{array}$} & \multicolumn{2}{|c|}{$\begin{array}{c}\theta \\
75 \mathrm{~cm} \\
\left(\mathrm{~m}^{3} \mathrm{~m}^{-3}\right)\end{array}$} \\
\hline & & & Mean & $\mathrm{Sd}$ & Mean & $\mathrm{Sd}$ & Mean & $\mathrm{Sd}$ & Mean & $\mathrm{Sd}$ & Mean & $\mathrm{Sd}$ \\
\hline Feb-07 & 28 & 288 & 19.0 & 2.9 & 0.58 & 0.12 & 23.8 & 0.5 & 0.44 & 0.01 & 0.45 & 0.01 \\
\hline Mar-07 & 31 & 293 & 18.5 & 3.8 & 0.58 & 0.16 & 23.5 & 0.6 & 0.42 & 0.02 & 0.42 & 0.01 \\
\hline Apr-07 & 30 & 473 & 19.8 & 2.8 & 0.60 & 0.12 & 24.3 & 0.5 & 0.44 & 0.01 & 0.43 & 0.01 \\
\hline May-07 & 31 & 271 & 18.4 & 2.8 & 0.63 & 0.14 & 24.6 & 0.6 & 0.43 & 0.01 & 0.43 & 0.01 \\
\hline Jun-07 & 30 & 222 & 15.8 & 3.5 & 0.59 & 0.13 & 24.5 & 0.8 & 0.43 & 0.01 & 0.41 & 0.01 \\
\hline Jul-07 & 31 & 116 & 16.0 & 3.5 & 0.68 & 0.15 & 24.3 & 0.7 & 0.41 & 0.02 & 0.41 & 0.01 \\
\hline Aug-07 & 31 & 238 & 16.5 & 3.9 & 0.67 & 0.16 & 24.1 & 0.6 & 0.43 & 0.03 & 0.41 & 0.01 \\
\hline Sep-07 & 30 & 210 & 18.1 & 4.0 & 0.80 & 0.25 & 24.4 & 0.8 & 0.42 & 0.02 & 0.42 & 0.01 \\
\hline Oct-07 & 31 & 241 & 20.4 & 3.1 & 0.81 & 0.19 & 25.1 & 0.7 & 0.43 & 0.02 & 0.41 & 0.01 \\
\hline Nov-07 & 30 & 204 & 19.5 & 3.5 & 0.66 & 0.13 & 24.8 & 0.6 & 0.44 & 0.01 & 0.42 & 0.01 \\
\hline Dec-07 & 31 & 337 & 19.7 & 4.3 & 0.67 & 0.15 & 24.8 & 0.9 & 0.44 & 0.01 & 0.43 & 0.01 \\
\hline Jan-08 & 30 & 44 & 18.6 & 4.1 & 0.76 & 0.19 & 24.7 & 0.9 & 0.38 & 0.02 & 0.40 & 0.01 \\
\hline Feb-08 & 29 & 142 & 17.4 & 4.1 & 0.76 & 0.18 & 24.5 & 0.7 & 0.40 & 0.03 & 0.39 & 0.01 \\
\hline
\end{tabular}

\subsection{Sapwood area and radial profiles of sap flux}

For cacao, the staining experiment revealed that the stem cross section consisted almost entirely of conducting sapwood. Only the very central portion $(<1 \mathrm{~cm}$ radius $)$ of the stem was left uncoloured in all studied individuals. Also in sampled Gliricidia trees up to $12 \mathrm{~cm}$ diameter (4 individuals) staining showed that the stem was mainly composed of sapwood. In Gliricidia trees with a larger diameter (10 individuals) only the outer $25 \mathrm{~mm}$ of the xylem were active in water transport, indicating that heartwood formation occurred in these larger trees. The heart- and sapwood could also be distinguished based on wood colour. In cacao trees the sap flux density at a depth of 24 to $48 \mathrm{~mm}$ below cambium was on average $82 \%$ of the sap flux density in the outer reference depth. In Gliricidia average normalized sap flux density at that depth was $62 \%$. 


\subsection{Sap flux and sap flux model parameters}

Diurnal patterns of sap flux density observed in cacao and Gliricidia differed (Fig. 1). In Gliricidia sap flux density increased rapidly after sunrise and reached a maximum early in the day. Near-maximal sap flux densities were then maintained for several hours and sap flux only declined in the late afternoon. In contrast, sap flux density in cacao showed a later rise after sunrise, reached a maximum later in the day and started to decline around midday so that a pronounced plateau was absent. Average daily maximum sap flux density in Gliricidia $\left(22.5 \pm 5.2 \mathrm{~g} \mathrm{~cm}^{-2} \mathrm{~h}^{-1}\right)$ was significantly lower than in cacao $\left(31.1 \pm 8.6 \mathrm{~g} \mathrm{~cm}^{-2} \mathrm{~h}^{-1}\right)$. Nevertheless, there were no significant differences in daily integrated flux which was $151.9 \pm 36.5$ and $149.9 \pm 37.7 \mathrm{~g} \mathrm{~cm}^{-2} \mathrm{~d}^{-1}$ for cacao and Gliricidia respectively. We assume that nighttime sap flux densities were negligible as temperature outputs of the thermal dissipation sensors returned to stable values most nights suggesting that refilling of internal reserves was completed. Moreover, VPD was close to zero because of rainfall which occurred during most nights.

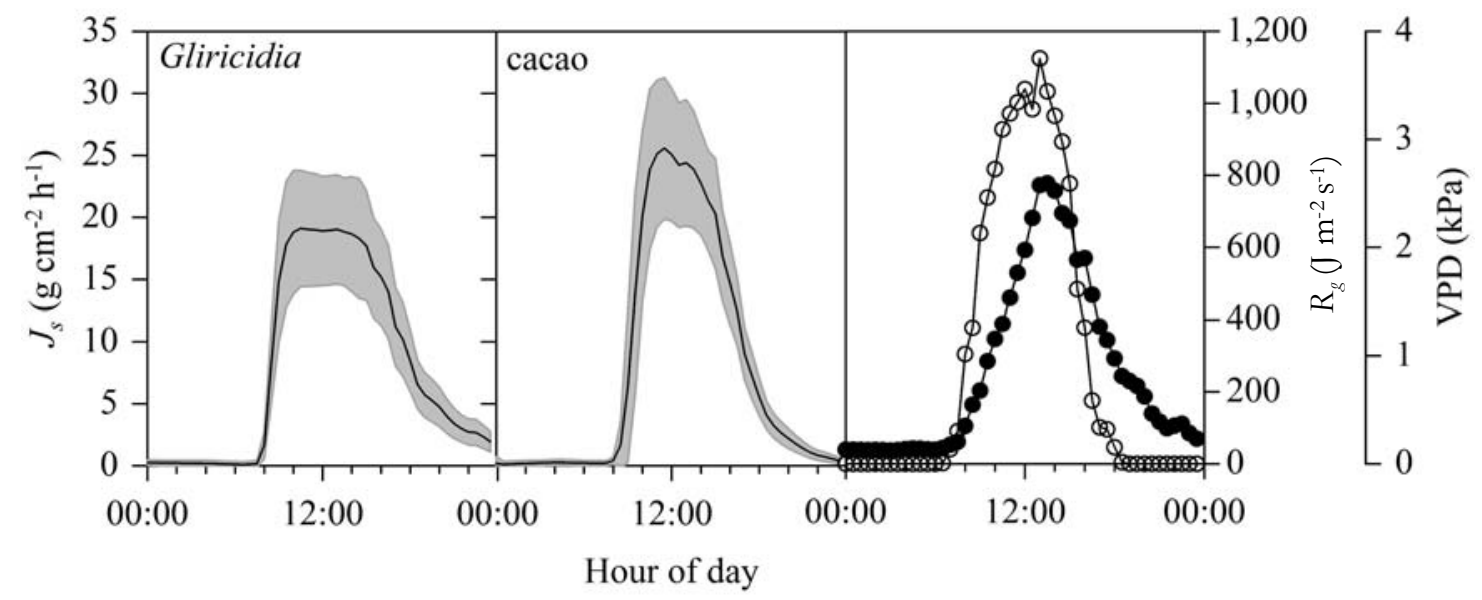

Figure 1: Course of mean sap flux density $\left(J_{s}\right)$ in Gliricidia and cacao trees $(\mathrm{n}=18$ per species, means and standard deviation as shaded area) on a bright day (Feb/22/07) under moist soil conditions. Additionally global radiation $\left(\mathrm{R}_{g}\right.$, open symbols) and vapour pressure deficit (VPD, filled symbols) are given.

The sap flux model predicted half hourly flux densities satisfactorily (Table 3). For individual trees $\mathrm{R}_{\text {adj }}^{2}$ ranged from 0.88 to 0.96 for cacao and from 0.93 to 0.96 for Gliricidia. The estimated model parameters for individual cacao trees were in general more variable as for Gliricidia trees (Table 3). For a single Gliricidia tree estimated model parameters showed outlying values, although the model fit for that specific tree was appropriate. The differences in measured maximum flux density between the two species were reflected in model parameter $a$, which was on average 29.8 and $20.0 \mathrm{~g} \mathrm{~cm}^{-2} \mathrm{~h}^{-1}$ for cacao and Gliricidia respectively. Also the other model parameters, which determine the shape of light and VPD responses, differed significantly between cacao and Gliricidia. Higher values of $b$ indicated higher light requirements for cacao, while 
higher values of $c$ and $d$ for cacao suggested that sap flux in Gliricidia responded earlier to increasing VPD than did sap flux in cacao.

Table 3: Estimated model parameters (28 days in Feb 2007) for cacao and Gliricidia trees (means and standard deviations, $\mathrm{n}=18$ ). Significant differences $(\mathrm{p}<0.05)$ between species for the individual model parameters are indicated by different small letters.

\begin{tabular}{|c|c|c|c|c|c|c|c|c|c|c|c|}
\hline \multirow[t]{2}{*}{ Species } & \multirow[t]{2}{*}{$\begin{array}{c}\mathrm{R}_{\text {adj }}^{2} \\
(-)\end{array}$} & \multicolumn{2}{|c|}{$\begin{array}{c}\text { RMSE } \\
\left(\mathrm{g} \mathrm{cm}^{-2} \mathrm{~h}^{-1}\right) \\
\end{array}$} & \multicolumn{2}{|c|}{$\begin{array}{c}a \\
\left(\mathrm{~g} \mathrm{~cm}^{-1} \mathrm{~h}^{-1}\right) \\
\end{array}$} & \multicolumn{2}{|c|}{$\begin{array}{c}b \\
\left(\mathrm{~J} \mathrm{~m}^{-2} \mathrm{~s}^{-1}\right) \\
\end{array}$} & \multicolumn{2}{|c|}{$\begin{array}{c}c \\
(\mathrm{kPa}) \\
\end{array}$} & \multicolumn{2}{|c|}{$\begin{array}{c}d \\
(\mathrm{kPa}) \\
\end{array}$} \\
\hline & & Mean & $\mathrm{Sd}$ & Mean & $\mathrm{Sd}$ & Mean & $\mathrm{Sd}$ & Mean & $\mathrm{Sd}$ & Mean & $\mathrm{Sd}$ \\
\hline Theobroma cacao & 0.94 & 1.58 & 0.39 & $29.8^{\mathrm{a}}$ & 8.17 & $192.5^{\mathrm{a}}$ & 107.59 & 0.8 & 0.15 & $0.2^{\mathrm{a}}$ & 0.06 \\
\hline Gliricidia sepium & 0.95 & 2.13 & 0.57 & $20.0^{b}$ & 4.30 & $79.6^{\mathrm{b}}$ & 33.08 & 0.5 & 0.14 & $0.1^{\mathrm{b}}$ & 0.05 \\
\hline
\end{tabular}

Daily integrated sap flux density (average over 18 individuals) showed a strong linear relationship with both daily average VPD and the daysum of $\mathrm{R}_{g}$ (Fig. 2). The relationship with VPD gave values for $\mathrm{R}^{2}{ }_{\text {adj }}$ of 0.83 and 0.76 for cacao and Gliricidia respectively $(\mathrm{p}<0.001)$. The relationship with $\mathrm{R}_{g}$ was weaker in both species with an $\mathrm{R}^{2}{ }_{\text {adj }}$ of 0.70 for cacao and 0.56 for Gliricidia . Similar graphs covering the whole study period revealed that daily integrated sap flux density saturates at days with higher VPD.

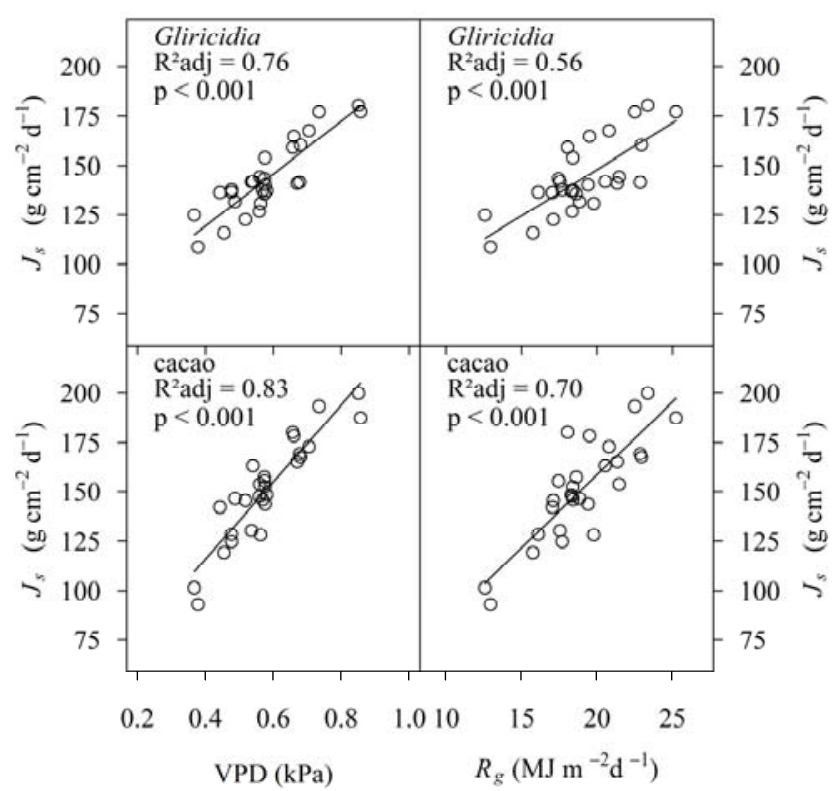

Figure 2: Average integrated daily sap flux of cacao $(\mathrm{n}=18)$ and Gliricidia $(\mathrm{n}=18)$ trees in relation to vapor pressure deficit $(\mathrm{VPD})$ and global radiation $\left(R_{g}\right)$ for a period of 28 days in February 2007.

The analysis of data obtained in January 2008, a month characterized by low precipitation and relatively low soil moisture content, showed no clear effect of soil moisture on the relationship between daily integrated sap flux and VPD. This indicates that soil moisture was not limiting during the study period. 


\subsection{Water use and transpiration in relation to tree characteristics}

Over the 13 -month study period, daily water use rates $\left(Q_{\text {mean }}\right)$ of cacao trees averaged $10.0 \mathrm{~kg}$ $\mathrm{d}^{-1}$, while values for Gliricidia trees were in general higher and averaged $14.0 \mathrm{~kg} \mathrm{~d}^{-1}$ (Table 4). Averaged over the individuals, the maximum daily water use rate $\left(Q_{\max }\right)$ was $17.3 \mathrm{~kg} \mathrm{~d}^{-1}$ in cacao and $23.0 \mathrm{~kg} \mathrm{~d}^{-1}$ in Gliricidia. In both species maximum water use rates were positively correlated with tree diameter (Fig. 3). In cacao there was also a significant relation between tree height and maximum water use $\left(\mathrm{R}_{\text {adj }}^{2}=0.31, \mathrm{p}=0.010\right.$, not shown). For Gliricidia this relationship was not significant $\left(\mathrm{R}_{\text {adj }}^{2}=0.14, \mathrm{p}=0.070\right)$.

Table 4: Monthly averages of daily tree water use rates $(Q)$ and transpiration at tree level $\left(T_{\text {tree }}\right)$ for cacao and Gliricidia trees ( $\mathrm{n}=9$ per species) over the study period. Also given is the estimated stand transpiration $\left(T_{\text {stand }}\right)$.

\begin{tabular}{|c|c|c|c|c|c|c|c|c|c|c|}
\hline \multirow[t]{3}{*}{ Month } & \multirow[t]{3}{*}{$\begin{array}{l}\text { Days } \\
\text { (n) }\end{array}$} & \multicolumn{4}{|c|}{$\begin{array}{c}\text { Mean } Q \\
\left(\mathrm{~kg} \mathrm{~d}^{-1}\right)\end{array}$} & \multicolumn{4}{|c|}{$\begin{array}{c}\text { Mean } T_{\text {tree }} \\
\left(\mathrm{mm} \mathrm{d}^{-1}\right)\end{array}$} & \multirow[t]{3}{*}{$\begin{array}{c}\text { Mean } T_{\text {stand }} \\
\left(\mathrm{mm} \mathrm{d}^{-1}\right)\end{array}$} \\
\hline & & \multicolumn{2}{|c|}{$\begin{array}{c}\text { Theobroma } \\
\text { cacao }\end{array}$} & \multicolumn{2}{|c|}{$\begin{array}{l}\text { Gliricidia } \\
\text { sepium }\end{array}$} & \multicolumn{2}{|c|}{$\begin{array}{c}\text { Theobroma } \\
\text { cacao }\end{array}$} & \multicolumn{2}{|c|}{$\begin{array}{l}\text { Gliricidia } \\
\text { sepium }\end{array}$} & \\
\hline & & Mean & $\mathrm{Sd}$ & Mean & $\mathrm{Sd}$ & Mean & $\mathrm{Sd}$ & Mean & $\mathrm{Sd}$ & \\
\hline Feb-07 & 28 & 9.2 & 4.2 & 13.4 & 3.2 & 0.46 & 0.20 & 0.46 & 0.39 & 1.4 \\
\hline Mar-07 & 31 & 9.5 & 4.4 & 13.1 & 3.5 & 0.47 & 0.21 & 0.44 & 0.36 & 1.4 \\
\hline Apr-07 & 30 & 9.6 & 4.5 & 13.1 & 3.9 & 0.47 & 0.21 & 0.42 & 0.29 & 1.4 \\
\hline May-07 & 30 & 10.3 & 5.1 & 14.9 & 4.2 & 0.50 & 0.22 & 0.48 & 0.35 & 1.6 \\
\hline Jun-07 & 30 & 9.6 & 4.9 & 14.7 & 4.2 & 0.47 & 0.20 & 0.50 & 0.42 & 1.5 \\
\hline Jul-07 & 31 & 10.2 & 5.1 & 14.6 & 4.6 & 0.50 & 0.21 & 0.45 & 0.29 & 1.5 \\
\hline Aug-07 & 27 & 9.6 & 4.3 & 13.3 & 4.5 & 0.47 & 0.19 & 0.41 & 0.25 & 1.4 \\
\hline Sep-07 & 0 & - & - & - & - & - & - & - & - & - \\
\hline Oct-07 & 31 & 11.1 & 5.6 & 14.2 & 4.2 & 0.57 & 0.33 & 0.50 & 0.50 & 1.6 \\
\hline Nov-07 & 30 & 10.1 & 6.3 & 14.6 & 3.5 & 0.51 & 0.31 & 0.53 & 0.53 & 1.5 \\
\hline Dec-07 & 30 & 10.0 & 4.8 & 14.3 & 3.3 & 0.53 & 0.36 & 0.51 & 0.49 & 1.5 \\
\hline Jan-08 & 30 & 10.8 & 4.5 & 14.2 & 3.9 & 0.58 & 0.40 & 0.44 & 0.27 & 1.6 \\
\hline Feb-08 & 22 & 10.3 & 4.8 & 14.1 & 4.6 & 0.55 & 0.41 & 0.42 & 0.23 & 1.5 \\
\hline Overall & & 10.0 & 4.6 & 14.0 & 3.3 & 0.51 & 0.26 & 0.46 & 0.36 & 1.5 \\
\hline
\end{tabular}

In cacao maximum tree water use was positively correlated to leaf area measured in OctoberDecember $2007\left(\mathrm{R}_{\text {adj }}^{2}=0.72, \mathrm{p}=0.002, \mathrm{n}=9\right)$. Increasing openness of the overstorey canopy (gap fraction) also influenced maximal tree water use rates in cacao. Maximum water use in cacao trees increased significantly with decreasing gap fraction $\left(\mathrm{R}^{2}{ }_{\text {adj }}=0.39, \mathrm{p}=0.04\right)$ (Fig. 4). This trend was particularly clear at gap fractions above 0.5 . Tree diameter and leaf area also increased with decreasing gap fractions and had values for $\mathrm{R}_{\text {adj }}^{2}$ of $0.33(\mathrm{p}=0.062)$ and $0.34(\mathrm{p}=0.057)$, respectively. In Gliricidia maximum water use tended to increase with increasing crown projection $\operatorname{area}\left(\mathrm{R}_{\text {adj }}^{2}=0.33, \mathrm{p}=0.061\right)$.

Average tree level transpiration over the study period varied strongly between individuals. It was between 0.3 and $1.1 \mathrm{~mm} \mathrm{~d}^{-1}$ (average $0.51 \mathrm{~mm} \mathrm{~d}^{-1}$ ) for cacao trees and 0.1 to $1.3 \mathrm{~mm} \mathrm{~d}^{-1}$ (average $0.46 \mathrm{~mm} \mathrm{~d}^{-1}$ ) for Gliricidia trees (Table 4). Stand level transpiration averaged $1.5 \mathrm{~mm} \mathrm{~d}^{-1}$ over the 13 month study period to which cacao trees contributed $70 \%$. 


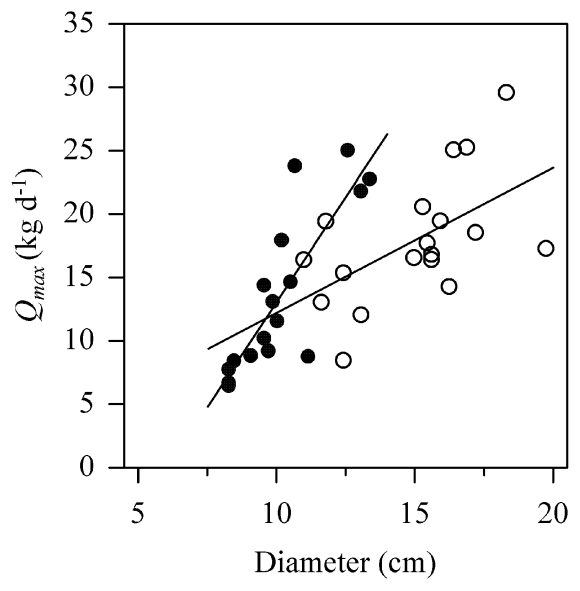

Figure 3: Relationship between tree diameter and average maximum water use (28 days in Feb 2007) for cacao $\left(\mathrm{R}^{2}{ }_{\text {adj }}=0.68, \mathrm{p}<0.001\right.$, closed symbols) and Gliricidia $\left(\mathrm{R}^{2}\right.$ adj $=0.27, \mathrm{p}=0.016$, open symbols). Data from 18 trees is presented for both species.

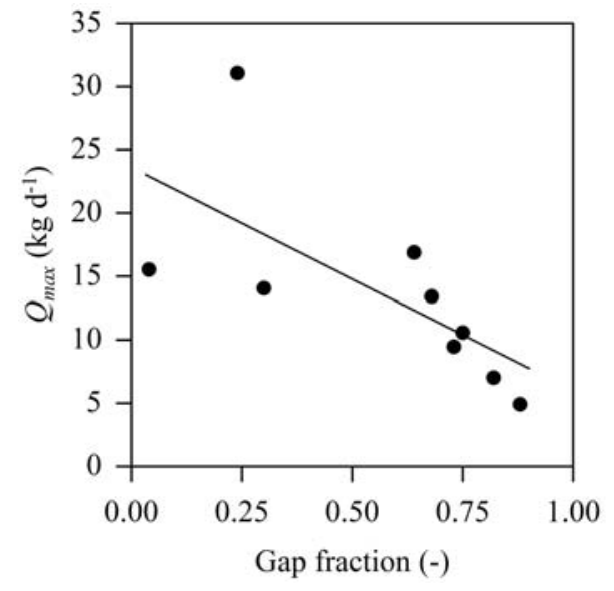

Figure 4: Gap fraction (-) above cacao trees and average maximum water use in cacao from OctoberDecember $2007\left(\mathrm{R}^{2}\right.$ adj $\left.=0.39, \mathrm{p}=0.043, \mathrm{n}=9\right)$.

\section{Discussion}

\subsection{Sap flux density and diurnal sap flux patterns}

Measured maximum sap flux densities were 31.1 and $22.5 \mathrm{~g} \mathrm{~cm}^{-2} \mathrm{~h}^{-1}$ in cacao and Gliricidia, respectively and are comparable with observations made for different tropical tree species, belonging to a large number of genera, where maximum sap flux density is roughly between 5 and $40 \mathrm{~g} \mathrm{~cm}^{-2} \mathrm{~h}^{-1}$ (Granier et al., 1996; Meinzer et al., 2001). However, values as high as $70 \mathrm{~g} \mathrm{~cm}^{-2} \mathrm{~h}^{-1}$ have been reported (Becker, 1996; O'Brien et al., 2004). In 8-year-old cacao trees in Sumatra, Indonesia maximum sap flux densities were between 15 and $35 \mathrm{~g} \mathrm{~cm}^{-2} \mathrm{~h}^{-1}$ (Colas et al., 1999). For 2year-old Gliricidia trees in an alley cropping system, maximum sap flux densities were around $20 \mathrm{~g}$ $\mathrm{cm}^{-2} \mathrm{~h}^{-1}$ (Tournebize and Boistard, 1997).

The diurnal course of sap flux differed between cacao and shade trees (Fig. 1). In cacao sap flux peaked late during the day and declined gradually after that. In contrast, sap flux in Gliricidia reached a maximum early in the day, followed by a plateau lasting for several hours. Physiological differences between the two species possibly contributed to this. Colas et al. (1999) observed a similar pattern in cacao where sap flux density reached a peak and then decreased gradually throughout the late morning and afternoon. This was explained by stomatal closure in cacao under conditions of high evaporative demand. However, the same study suggested that cacao trees in a monoculture were able to maintain high sap flux rates for a longer time when soil water availability was sufficient. Another possible explanation for the different diurnal courses of sap flux density is the different microclimate $\left(R_{g}\right.$ and VPD) to which cacao trees and Gliricidia trees 
are subjected. A recent study in coffee agroforestry systems (van Kanten and Vaast, 2006) provides strong indications of the influence of shading regimes and associated microclimate on diurnal sap flux patterns in coffee plants. During the dry season coffee plants under dense shade started reducing transpiration at higher VPD levels compared to coffee plants under light shade or in full sun. This was attributed to the distinct microclimate which these coffee trees growing under a dense shade canopy experienced as a result of strong uncoupling from the bulk atmosphere.

Our data also provide indications for the role of microclimate on observed sap flux density patterns. Model parameters suggested higher light saturation levels in cacao compared to Gliricidia, which could result from a different canopy structure of both species. In a sparse canopy of well exposed shade trees, leaf illumination can be expected to become optimal under relatively low $R_{g}$. In the shaded and multi-layered canopy of cacao, individual leaves can still make use of increasing light levels even when $R_{g}$ is already high, hence the higher value of $b$. The remaining model parameters $c$ and $d$ suggest a rise in sap flux density in Gliricidia under conditions of lower evaporative demand (VPD) compared to cacao. As in the study of van Kanten and Vaast (2006), this could reflect a stronger uncoupling of cacao trees from the atmosphere due to the effect of shade trees, although a stronger uncoupling at the leaf level (cacao has a larger leaf size as Gliricidia) could contribute to this as well.

\subsection{Tree water use}

Scaling of sap flux density data to tree water use rates gave, for the two species combined, maximum water use rates between 9.1 and $32.4 \mathrm{~kg} \mathrm{~d}^{-1}$ for trees with a diameter between 8.3 and $19.7 \mathrm{~cm}$. This range of maximum water use rates is in agreement with observations for trees of similar diameter in four Australian rainforest types (McJannet et al., 2007) and data presented for trees in mixed young tree plantations in the Philippines (Dierick and Hölscher, 2009). The mean daily tree water use over the 13 month study period differed between the two species, being on average $10.0 \mathrm{~kg} \mathrm{~d}^{-1}$ in cacao trees compared to $14.0 \mathrm{~kg} \mathrm{~d}^{-1}$ in Gliricidia trees (Table 4). This difference can be attributed to the smaller average diameter of sampled cacao trees compared to Gliricidia trees (Table 1). Even though daily cumulated sap flux densities did not differ among species, higher water use rates are predicted for the larger Gliricidia trees due to a larger conductive sapwood area in large trees.

However, Fig. 3 clearly shows that both species exhibit a different relationship between estimated maximum water use and tree diameter. The lower water use rates in Gliricidia compared to cacao for trees of a given diameter are a consequence of the limited sapwood depth in larger 
Gliricidia trees. Differences in sap flux density do not play a role here as cumulated daily flux is almost identical for the two species. The different water use to diameter relation in cacao and Gliricidia would contrast with the hypothesis that tree water use scales universally with tree size and is essentially species independent (Meinzer, 2003; Meinzer et al., 2005). Note however that the narrow diameter in this study potentially highlights the differences between the two species and that the latter statement should thus be taken with care. Fig. 3 also suggests that the relation between tree diameter and tree water use is weaker for Gliricidia than for cacao. This might be explained by a higher variability of the conducting sapwood area and/or incorrect assumptions on how sapwood activity declined with depth.

Maximum tree water use rates in cacao were negatively correlated to gap fraction, suggesting higher water use in trees with increased shading. Although the reverse could be expected, similar observations exist for coffee (van Kanten and Vaast, 2006). Coffee grown in full sun had higher transpiration rates when expressed per unit leaf area than coffee grown under shade trees, but the reverse was generally true when transpiration rates were expressed per unit ground area. The increased transpiration per unit ground surface of coffee under shade trees was attributed to increased vegetative growth. Also for cacao stands in Ghana enhanced vegetative growth under shade trees was observed (Isaac et al., 2007). Under three shade tree species cacao tree biomass was higher (in two treatments this was significant) than in unshaded cacao trees. It was also found that cacao tree biomass decreased with increasing distance to the shade tree. The correlations we found for individual trees between gap fraction on the one hand and tree diameter and tree leaf area on the other hand, would suggest that also in our study enhanced vegetative growth under increased shading occurred. This enhanced vegetative growth in combination with increasing water use rates of shaded cacao trees suggests that shading could lead to increasing transpiration rates per unit ground area at stand level as the study of van Kanten and Vaast (2006) demonstrated. In addition, water use by the shade trees would further increase the total stand transpiration. 


\subsection{Transpiration rates}

Tree level transpiration rates, i.e. tree water use expressed per unit crown area, were around $0.5 \mathrm{~mm} \mathrm{~d}^{-1}$ for both species with a high variability between individuals. In a secondary forest patch in Vietnam, estimated tree level transpiration rates were generally higher, between 0.4 and $2.9 \mathrm{~mm} \mathrm{~d}^{-1}$, and also highly variable between individuals (Giambelluca et al., 2003). The authors suggested a possible role of tree species, tree crown exposure, edge effect, vine infestation and leaf area index in explaining the different tree level transpiration rates.

During our study, the average stand transpiration rate in the cacao-Gliricidia agroforestry system was estimated at $1.5 \mathrm{~mm} \mathrm{~d}^{-1}$. We only know of one study where transpiration in cacao was measured by means of xylem sap flux measurements. Also using the Granier method, Colas et al. (1999) estimated the transpiration in a cacao monoculture and cacao growing under coconut in Sumatra, Indonesia. In these stands transpiration was 1.2 and $1.3 \mathrm{~mm} \mathrm{~d}^{-1}$ in a monoculture and in association with coconut respectively.

Rather than transpiration rates, most literature on water relations in cacao stands provides estimates of stand evapotranspiration which includes evaporation from trees and litter layer after interception. Using eddy covariance techniques, evapotranspiration was determined experimentally for a mature cacao plantation near our study area in Central Sulawesi at $2.6 \mathrm{~mm} \mathrm{~d}^{-1}$ (Falk, 2004). For cacao with Erythrina poeppigiana and Cordia alliodora as shade trees in Costa Rica, Imbach et al. (1989) calculated a daily evapotranspiration of 2.7 to $2.8 \mathrm{~mm} \mathrm{~d}^{-1}$ respectively from pan-evaporation, a crop coefficient and measurements of rain interception. In a cacao stand under remaining forest trees in Sulawesi interception losses were estimated at 19\% of gross precipitation (Dietz et al., 2006). For the particular cacao agroforest where this study was conducted, interception was estimated to be around 14\% (L. Schwendenmann and G. Moser, unpublished data). Taking into account the amount of rainfall during our study, approximately $1.1 \mathrm{~mm} \mathrm{~d}^{-1}$ evaporated back to the atmosphere after interception. When added to our estimate of stand transpiration, this would give an average evapotranspiration rate $\left(2.6 \mathrm{~mm} \mathrm{~d}^{-1}\right)$ which is in good agreement with results from Falk (2004) and Imbach et al. (1989).

\section{Conclusions}

In the stand studied, water use characteristics of the two species differed substantially with respect to maximal sap flux density, response to atmospheric factors, and tree size relationships. The resulting transpiration rates at the stand level combined with estimates of rainfall interception are comparable to other observations of evapotranspiration. Remarkable was the influence shade trees may exert on stand level transpiration. Our data suggested that shade trees may in- 
crease enhance stand transpiration by their own water use and furthermore by enhancing water use rates of cacao trees.

\section{Acknowledgements}

This study was conducted in the framework of the joint Indonesian-German research project 'Stability of Tropical Rainforest Margins, Indonesia (STORMA)' funded by the German Research Foundation (SFB 552, sub-project B4). We also like to thank Masrillihardi Potabuga and Andi Sofyan for their valued assistance with the field work.

\section{References}

Andrade JL, Meinzer FC, Goldstein G, Holbrook NM, Cavelier J, Jackson P, Silvera K. 1998. Regulation of water flux through trunks, branches, and leaves in trees of a lowland tropical forest. Oecologia 115 : 463-471.

Becker P. 1996. Sap flow in Bornean heath and dipterocarp forest trees during wet and dry periods. Tree Physiology $16: 295-299$.

Clearwater M J, Meinzer FC, Andrade J L, Goldstein G, Holbrook N M. 1999. Potential errors in measurement of nonuniform sap flow using heat dissipation probes. Tree Physiology 19 : 681-687.

Colas H, Mouchet S, Rey H, Kitu WT. 1999. Une approche du comportement hybrique du cacaoyer (Theobroma cacao L.) par des mesures de flux de sève brute : comparaison entre une culture pure et une culture associée sous cocotier (Cocos nucifera L.) In: Efficacité de la production cacaoyère et la qualité du cacao au 21è. Actes. Lagos : Cocoa Producers' Alliance, 637-644. Conférence internationale sur la recherche cacaoyère. 12, 1996-11-17/199611-23, Salvador de Bahia, Brésil.

Delzon S, Sartore M, Granier A, Loustau D. 2004. Radial profiles of sap flow with increasing tree size in maritime pine. Tree Physiology 24 : 1285-1293.

Dierick D, Hölscher D. 2009 Species-specific tree water use characteristics in reforestation stands in the Philippines. Agricultural and Forest Meteorology 149 : 1317-1326.

Dietz J, Hölscher D, Leuschner C, Hendrayanto. 2006. Rainfall partitioning in relation to forest structure in differently managed montane forest stands in Central Sulawesi, Indonesia. Forest, Ecology and Management 237 : 170 178.

Edwards W R N, Becker P, and Čermák J. 1996. A unified nomenclature for sap flow measurements. Tree Physiology $17: 65-67$.

Falk U. 2004. Turbulent Fluxes of CO2, H2O and Energy in the Atmospheric Boundary Layer above Tropical Vegetation investigated by Eddy-Covariance Measurements. Dissertation: University of Göttingen.

FAO. 2009. Food and Agriculture Organization of the United Nations. http://faostat.fao.org (last visited: 29/04/2009)

Garcia Santos G. 2007. An ecohydrological and soils study in a montane cloud forest in the National Park of Garajonay, La Gomera (Canary Islands, Spain). Dissertation: Vrije Universiteit Amsterdam.

Giambelluca TW, Ziegler AD, Nullet MA, Truong DM, Tran LT. 2003. Transpiration in a small tropical forest patch. Agricultural and Forest Meteorology $117: 1-22$. 
Granier A. 1987. Evaluation of transpiration in a Douglas-fir stand by means of sap flow measurements. Tree Physiology $3: 309-320$.

Granier A, Anfodillo T, Sabatti M, Cochard H, Dreyer E, Tomasi M, Valentini R, Breda N. 1994.Axial and radial water-flow in the trunks of oak trees - a quantitative and qualitative analysis. Tree Physiology, 14 : 1383-1396.

Granier A, Huc R, Barigah ST. 1996. Transpiration of natural rain forest and its dependence on climatic factors. Agricultural and Forest Meteorology $78: 19-29$.

Imbach AC, Fassbender HW, Borel J, Beer J, Bonnemann A. 1989. Modelling agroforestry systems of cacao (Theobroma cacao) with laurel (Cordia alliodora) and cacao with poro (Erythrina poeppigiana) in Costa Rica. Agroforestry Systems $8:$ 267-287.

INRA. 2007. French National Institute for Agricultural Research, Avignon, France. URL http://www.avignon.inra.fr/can_eye (Last visited: 18/08/2008).

Isaac ME, Timmer VR, Quashie-Sam SJ. 2007. Shade tree effects in an 8-year-old cocoa agroforestry system: biomass and nutrient diagnosis of Theobroma cacao by vector analysis. Nutrient Cycling in Agroecosystems 78 : $155-$ 165.

Jarvis PG. 1976. The interpretation of variations in leaf water potential and stomatal conductance found in canopies in the field. Philosophical Transactions of the Royal Society of London. B. 273 : 593-610.

McJannet D, Fitch P, Disher M, Wallace J. 2007. Measurements of transpiration in four tropical rainforest types of north Queensland, Australia. Hydrological Processes 21 : 3549-3564.

Meinzer FC. 2003. Functional convergence in plant responses to the environment. Oecologia 134 : 1-11.

Meinzer FC, Goldstein G, Andrade JL. 2001. Regulation of water flux through tropical forest canopy trees: Do universal rules apply? Tree Physiology 21 : 19-26.

Meinzer FC, Bond BJ, Warren JM, Woodruff DR. 2005. Does water transport scale universally with tree size? Functional Ecology 19 : 558-565.

Montgomery PJ. 1981. Some thoughts on the life span of cocoa. Planter 57 : 604-609. Cited in: Olaiya AO, Fagbayide JA, Hammed LA, Aliyu MO. 2006. Comparison of potential pod yield and loss in old and rehabilitated cocoa plots. African Journal of Agricultural Research 1 : 189-193.

O'Brien JJ, Oberbauer SF, Clark DB. 2004. Whole tree xylem sap flow responses to multiple environmental variables in a wet tropical forest. Plant Cell and Environment $27: 551-567$.

Olaiya AO, Fagbayide JA, Hammed LA, Aliyu MO. 2006. Comparison of potential pod yield and loss in old and rehabilitated cocoa plots. African Journal of Agricultural Research 1 : 189-193.

Phillips, N, Oren R, and Zimmermann R. 1996. Radial patterns of xylem sap flow in non-, diffuse- and ring-porous tree species. Plant Cell Environment 19 : 983-990.

Poppenborg P, Hölscher D. The influence of emergent trees on rainfall distribution in a cacao agroforest (Sulawesi, Indonesia). Flora (in press DOI: 10.1016/j.flora.2008.10.003).

R Development Core Team. 2008. R: A language and environment for statistical computing. R Foundation for Statistical Computing: Vienna, Austria. ISBN 3-900051-07-0, URL http://www.R-project.org.

Schwendenmann, L., Veldkamp, E., Moser, G., Hölscher, D., Köhler, M., Clough,Y., Anas, I., Djajakirana, G., Erasmi, S., Hertel, D., Leitner, D., Leuschner, C., Michalzik, B., Propastin, P., Tjoa, A., Tscharntke, T., van 
Straaten, O., 2010. Effects of an experimental drought on the functioning of a cacao agroforestry system, Sulawesi, Indonesia. Global Change Biology 16, 1515-1530.

Steffan-Dewenter I, Kessler M, Barkmann J, Bos MM, Buchori D, Erasmi S, Faust H, Gerold G, Glenk K, Gradstein SR, Guhardja E, Harteveld M, Hertel D, Höhn P, Kappas M, Köhler S, Leuschner C, Maertens M, Marggraf R, Migge-Kleian S, Mogea J, Pitopang R, Schaefer M, Schwarze S, Sporn SG, Steingrebe A, Tjitrosoedirdjo SS, Tjitrosoemito S, Twele A, Weber R, Woltmann L, Zeller M, Tscharntke T. 2007. Tradeoffs between income, biodiversity, and ecosystem functioning during tropical rainforest conversion and agroforestry intensification. Proceedings of the National Academy of Science of the United States of America 104 : 4973-4978.

Tournebize R, Boistard S. 1997. Comparison of two sap flow methods for the estimation of tree transpiration. Ann. of Forest Science $55:$ 707-713.

van Kanten R, Vaast P. 2006. Transpiration of arabica coffee and associated shade tree species in sub-optimal, lowaltitude conditions of Costa Rica. Agroforestry Systems $67: 187-202$.

Veldkamp E, O'Brien JJ. 2000. Calibration of a frequency domain reflectometry sensor for humid tropical soils of volcanic origin. Soil Science Society of America Journal $64: 1549-1553$.

Zuidema PA, Leffelaar PA, Gerritsma W, Mommer L, Anten NPR. 2005. A physiological production model for cacao (Theobroma cacao): model presentation, validation and application. Agricultural Systems 84 : 195-225. 
CHAPTER 4
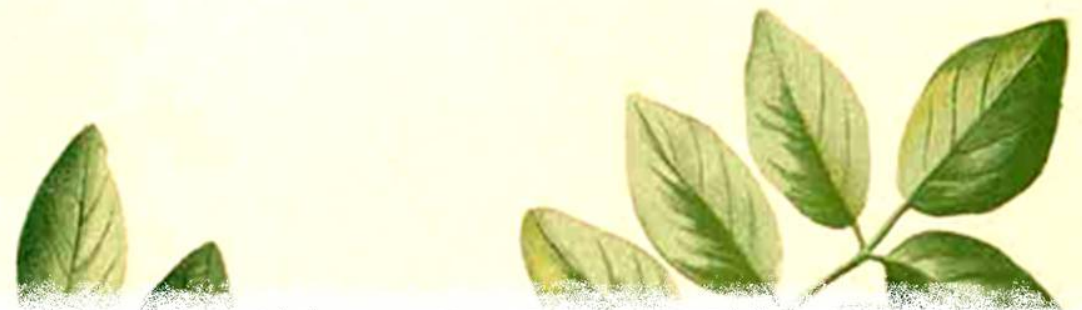

COMPARISON OF TREE WATER USE CHARACTERISTICS IN REFORESTATION AND AGROFORESTRY STANDS ACROSS THE TROPICS

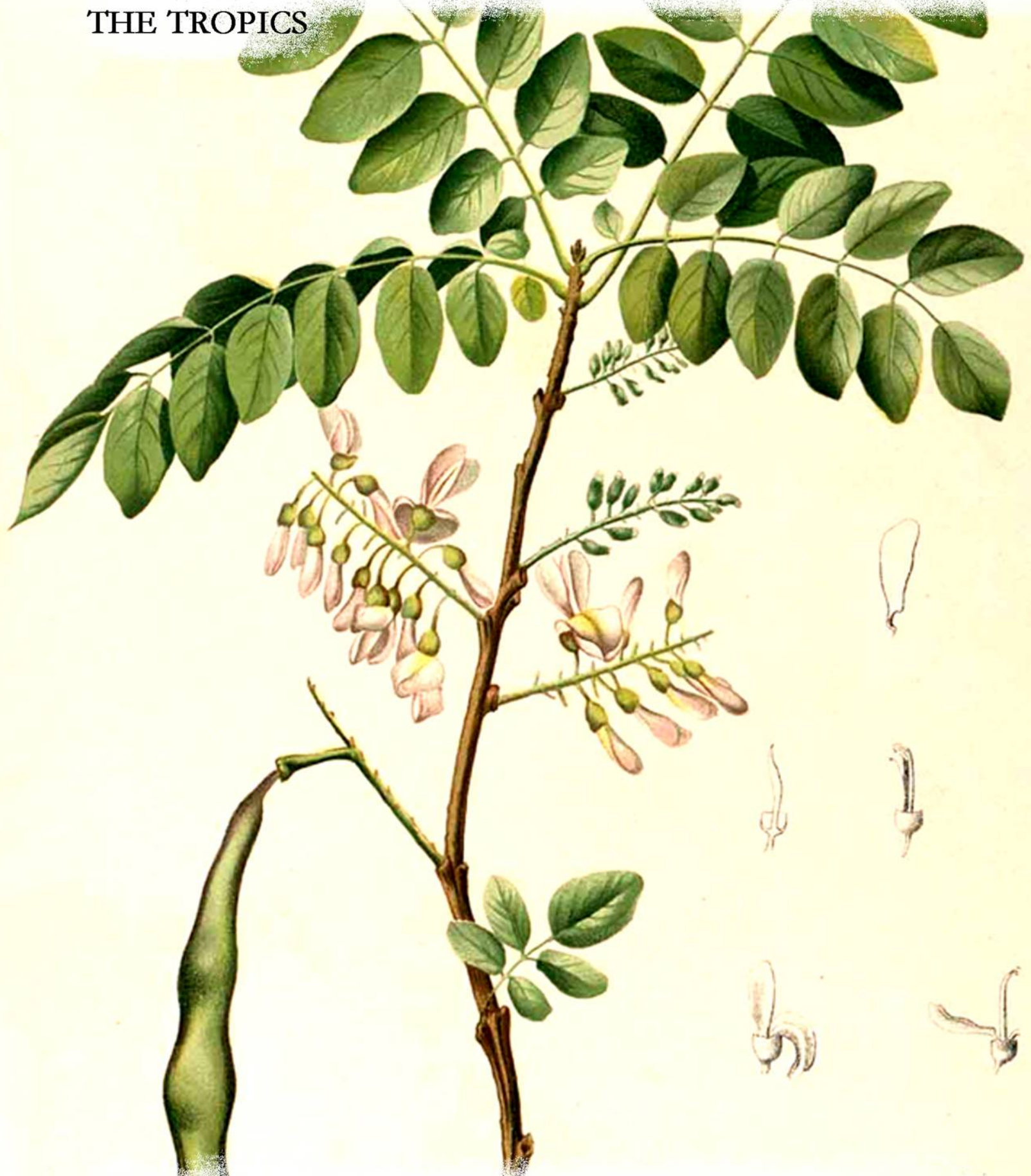

IN: T. TSCHARNTKE, C. LEUSCHNER, E. VELDKAMP, H.

FAUST, E. GUHARDJA, A. BIDIN (EDS.). TROPICAL RAINFORESTS AND AGROFORESTS UNDER GLOBAL CHANGE. 2010. SPRINGER, BERLIN 


\title{
Comparison of tree water use characteristics in reforestation and agroforestry stands across the tropics
}

\author{
Diego Dierick*, Norbert Kunert, Michael Köhler, Luitgard Schwendenmann \& \\ Dirk Hölscher
}

Tropical Silviculture and Forest Ecology, Burckhardt Institute, Georg-August-Universität Göttingen, Büsgenweg 1, 37077 Göttingen, Germany

\begin{abstract}
In the tropics, reforestations and agroforestry become increasingly important and may help mitigate climate change. However, high water use by trees may deplete water resources for associated crops or other purposes. Choice of tree species might reduce water use rates to acceptable levels, but available information on species-specific water use characteristics is scarce. We addressed the following questions: (1) do species differ in xylem sap flux response to fluctuating environmental conditions, (2) are there species-specific differences in quantities of water used, and specifically (3) do universal rules relating tree size to water use apply? This chapter combines data on tree sap flux and water use gathered in Indonesia, Panama and the Philippines. These studies applied the same methods and were conducted in recently established stands (5-12 years old when studied) characterised by small diameter trees and relatively simple stand structure. We analyse data from more than 100 trees belonging to 17 species using a simple sap flux model. Model application suggests species-specific differences in parameters such as maximal sap flux velocity and responses to radiation and vapour pressure deficit. With respect to the quantity of water used per tree, we observed a strong correlation between tree diameter and tree water use, which confirms earlier publications. However, e.g. in the stands in the Philippines where tree diameter explained $65 \%$ of observed variation, some species clearly followed distinct trajectories. For a given diameter, up to twofold differences in tree water use among species were observed. Our findings thus support the idea that species selection can be used to control tree water use of future reforestations and within agroforestry systems. This will be especially relevant in areas where water resources are limited already or where climate scenarios predict decreasing precipitation.
\end{abstract}

Keywords: Indonesia, Panama, Philippines, sap flux, tree size, tree species

\footnotetext{
* Corresponding author. Tel.: +49 551 399556; Fax: +49 551 394019; E-mail address: ddieric@gwdg.de (D. Dierick)
} 


\section{Introduction}

Natural forests in the tropics are still being converted at a high rate. Many of the former forest areas have been degraded, fail to produce goods and do not contribute to the protection of climate and biodiversity. For the management of buffer zones around remaining protected forests as well as for the restoration of degraded land, reforestation and agroforestry can be suitable measures. The re-introduction of trees into the landscape and especially reforestations have however been criticised because trees are potentially heavy water users and might deplete water resources (Jackson et al. 2005). From a global synthesis it was concluded that annual runoff was on average reduced by $44 \%$ and by $31 \%$ when reforesting grass- and shrubland, respectively (Farley et al. 2005). Also trees in agroforestry may be problematic as they may reduce water availability for the main crops and additionally increase stand level transpiration. In Costa Rica, the estimated stand level transpiration by coffee with shade trees was on average twice as high as that of coffee grown without shade trees (van Kanten and Vaast 2006).

It has been suggested that a suitable tree species choice might reduce water use rates to acceptable levels (van Dijk and Keenan 2007). This contention is somewhat theoretical as available information on species-specific water use characteristics is scarce. Furthermore, the effectiveness of species selection is questionable as studies in diverse old-growth forests and a single-species tree plantation showed repeatedly that tree size is the main factor influencing tree water use (Cienciala et al. 2000; Meinzer et al. 2004; McJannet et al. 2007). Meinzer et al. (2005) suggested that, as a result of functional convergence, plants operating within given biophysical limitations, develop common patterns of sap flux and water use in relation to size characteristics across taxa. This would leave little room for species selection to serve as a tool to influence stand water use, at least if wood production or carbon fixation is a major goal.

A thorough analysis of the problem is difficult as single studies of sap flux and tree water use often lack sufficient replicates within a species and/or analyse a limited number of species. Comparison among studies is additionally hampered by differences in applied methods. Here we bring together data from three case studies namely from the Philippines (Dierick and Hölscher 2009), Indonesia (Köhler et al. 2010) and Panama (Kunert, unpublished data), which were conducted in relatively young reforestation and agroforestry stands. Our compilation comprises 106 individual trees belonging to 17 species, which were studied and analysed using the same protocol. In this data compilation, we concentrate on time periods with ample soil water supply and on trees fully in leaves. As a diagnostic tool, we apply a model that predicts sap flux density based on meteorological parameters. The following questions were addressed: (1) do species dif- 
fer in xylem sap flux response to fluctuating environmental conditions, (2) are there speciesspecific differences in quantities of water used, and specifically (3) do universal rules relating tree size to water use apply?

\section{Methods}

\subsection{Study sites}

In the Philippines, we worked on the island Leyte in the Eastern Visayas. Two study sites were located near the villages $\operatorname{Marcos}\left(10.765^{\circ} \mathrm{N}, 124.790^{\circ} \mathrm{E}\right)$ and $\operatorname{Patag}\left(10.736^{\circ} \mathrm{N}, 124.804^{\circ} \mathrm{E}\right)$ at an elevation of 30 and $40 \mathrm{~m}$ asl, respectively. Average rainfall in the region amounts to $2753 \mathrm{~mm}$ $\mathrm{y}^{-1}$ and rain is relatively evenly distributed throughout the year (PAGASA 2007). Average annual air temperature is $27.5^{\circ} \mathrm{C}$. The natural vegetation in the region is species-rich lowland dipterocarp forest (Langenberger 2006). After deforestation and intermittent cultivation, the degraded sites were reforested following the so called 'rainforestation' approach (Margraf and Milan 1996). This means reforesting with a mixture of native species, promoting the incorporation of fruit trees and combining fast growing trees with shade tolerant species. At the time of the field study, from June to August 2006 at Marcos and July to September 2007 at Patag, both stands were 12 years old. Stem density was 796 and 1367 stems ha ${ }^{-1}$ in Marcos and Patag, respectively. We selected ten tree species, eight of which were native to the region (Table 1). Each species was represented by five individuals selected to have well exposed crowns. Only for Hopea plagata S. Vidal, a species with an in general smaller stature, some individuals had little exposed crowns.

In Indonesia, our study site was located in Central Sulawesi in the vicinity of the village of Marena $\left(1.552^{\circ} \mathrm{S}, 120.020^{\circ} \mathrm{E}\right)$ at $560 \mathrm{~m}$ asl. Measurements made between 2002 and 2006 at Gimpu (5 km south of Marena, $471 \mathrm{~m}$ asl) show that the mean air temperature is $25.5{ }^{\circ} \mathrm{C}$ and annual rainfall in the region is around $2092 \mathrm{~mm} \mathrm{y}^{-1}$. Rainfall shows a weak bimodal pattern with rainy seasons (>100 mm per month) from March to June and October to December. The structure and species composition of surrounding natural forest, which is usually only remaining at higher elevations, was described by Gradstein et al. (2007). The studied agroforest was located on former agricultural land used for cultivating annual crops such as maize and was 6 years old at the time of study. Cacao (Theobroma cacao L.) was growing as crop under Gliricidia sepium (Jacq.) Kunth ex Steud. shade trees. The stem density was 1030 stems ha $^{-1}$ for cacao and 325 stems ha $^{-1}$ for Gliricidia. Both tree species were represented by 18 individuals and studied for a one-month period in February 2007. 


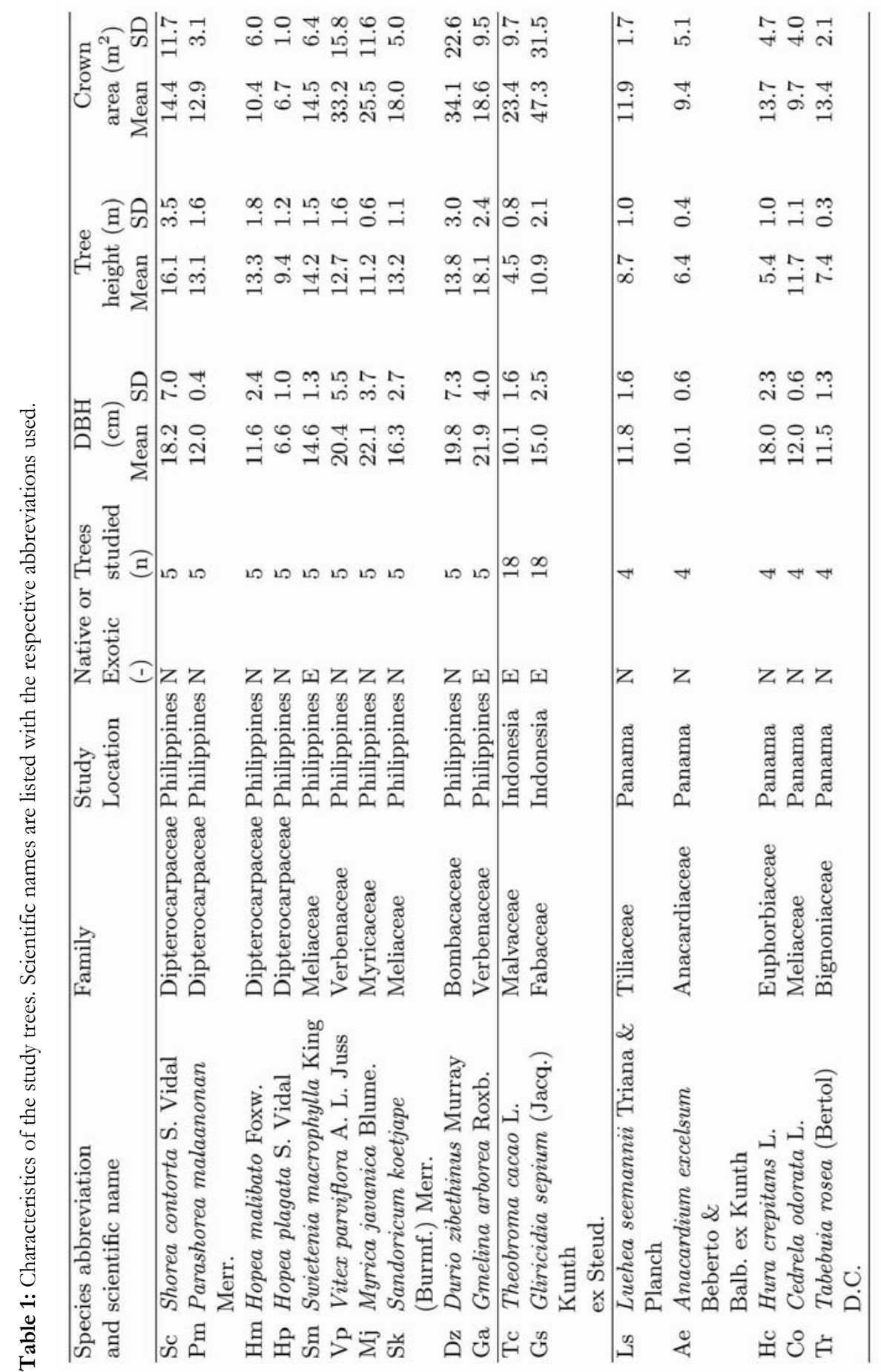


Our site in Panama was located near the village of Sardinilla, Central Panama $\left(9.317^{\circ} \mathrm{N}\right.$, $79.633^{\circ} \mathrm{W}$ ), which is approximately $50 \mathrm{~km}$ north of Panama City. The elevation of the site is 70 $\mathrm{m}$ asl. Mean annual precipitation measured at Barro Colorado Island (at $30 \mathrm{~km}$ distance) is 2627 $\mathrm{mm}$, with 25-50 mm per month during peak dry season (January-March) and $250 \mathrm{~mm}$ per month during the rainy season (May to November). The mean annual temperature of the region is 25.9 ${ }^{\circ} \mathrm{C}$ (STRI 2009). The original forest vegetation at the Sardinilla site was probably a tropical moist forest, similar to that of the Barro Colorado National Monument (Leigh et al. 1996). The study site was clear-cut in the 1950's and later used for cattle ranging. At the time of our study, the stands were 6 years old and stem density was about 1100 stems $\mathrm{ha}^{-1}$. Five tree species growing in monocultures were studied with four replicates each during the rainy season between June and September 2007.

\subsection{Sap flux measurements}

Sap flux density $J_{s}\left(\mathrm{~g} \mathrm{~cm}^{-2} \mathrm{~h}^{-1}\right)$ was measured using $25 \mathrm{~mm}$ long thermal dissipation probes (Granier 1985). Per study tree, two sensor pairs were installed on opposite sides of the tree trunk in the outermost xylem. Sensors were shielded and protected by styrofoam boxes, reflective foil, and plastic foil. The thermocouple output from the thermal dissipation probes was measured every 30 seconds and 5 or 30 minute averages were stored using dataloggers and attached multiplexers (CR1000 and AM16/32, Campbell Scientific Inc., Logan, UT, USA). Sap flux density was calculated from raw temperature data using the calibration equation determined by Granier (1987).

\subsection{Radial sap-flux profiles and water use rates}

Radial profiles of sap flux density $\mathrm{J}_{\mathrm{s}}$ were used to determine tree water use. Therefore $J_{s}$ was measured at one or two additional depths below the cambium and expressed relatively (\%) to concurrent measurements at the outer reference depth. Sap flow of ring-shaped stem crosssections was then calculated, taking into account the cross-sectional area of the ring corresponding with the respective installation depth, $J_{s}$ as measured at reference depth at the outer xylem, and the normalised profile of $J_{s}$ for the species considered (Hatton et al. 1990; Meinzer et al. 2005). Contributions of the different cross sections were added to determine total tree sap flow $\left(\mathrm{g} \mathrm{h}^{-1}\right)$ and summed over a day to give daily tree water use rates $\mathcal{Q}\left(\mathrm{kg} \mathrm{d}^{-1}\right)$. Water use rates were also expressed as transpiration rates $\left(T, \mathrm{~mm} \mathrm{~d}^{-1}\right)$ by dividing $Q$ by the crown projection area of the respective tree $\left(\mathrm{m}^{2}\right)$. 


\subsection{Sap flux density model}

We used a model to capture species characteristics of sap flux density and its responses to environmental conditions in analogy with work of O'Brien et al. (2004). The sap flux model used is a modification of the Jarvis-type model (Jarvis 1976) which was originally developed to describe stomatal responses to environmental drivers. The model takes the form of a multiplication of non-linear response functions, each depending on a single environmental factor. Each individual response function takes a value between zero and one, thus limiting the overall response if one or more environmental factors become suboptimal. The fact that environmental variables appear isolated in the model enhances the interpretation of model parameters. This multiplicative type of model has been widely used in a number of variations to describe canopy conductance (Herbst et al. 1999; Granier et al. 2000; Harris et al. 2004), stand transpiration (Oren and Pataki 2001; Whitley et al. 2008) and to describe sap flow patterns in individual trees (Cienciala et al. 2000).

We opted for a sap flux density model with radiation $R_{g}\left(\mathrm{~W} \mathrm{~m}^{-2}\right)$ and vapour pressure deficit $\operatorname{VPD}(\mathrm{kPa})$ as explanatory variables. Additional factors such as soil moisture conditions were not included because a preliminary exploration of the data indicated that this would not improve model fit much. The model form used was:

$$
J_{s \text { model }}=a \times \frac{\mathrm{R}_{g}}{b+\mathrm{R}_{g}} \times \frac{1}{1+\exp \frac{c-\mathrm{VPD}}{d}}
$$

with $J_{s \text { model }}$ the modeled sap flux density $\left(\mathrm{g} \mathrm{cm}^{-2} \mathrm{~h}^{-1}\right)$, a the maximum modeled sap flux density $\left(\mathrm{g} \mathrm{cm}^{-2} \mathrm{~h}^{-1}\right), b$ a parameter describing $\mathrm{R}_{g}$ response $\left(\mathrm{W} \mathrm{\textrm {m } ^ { - 2 }}\right)$ and $c, d$ parameters describing the VPD response $(\mathrm{kPa})$. Modeled sap flux density $J_{s \text { model }}$ reaches a maximum value $a$ when all environmental conditions are optimal. To account for the influence of radiation we introduced a commonly used hyperbolic response function which asymptotically approaches a value of 1 at high $R_{g}$. Parameter $b$ can be interpreted as a measure of the light saturation level. Assuming VPD is non-limiting, the sap flux reaches just over $90 \%$ of $a$ if radiation levels equal ten times parameter $b$. The response function used to describe the influence of VPD was taken from O'Brien et al. (2004). In this response function parameter $c$ equals the vapour pressure deficit for which $J_{s}$ model rises to half of the maximum value $\left(R_{g}\right.$ non-limiting), whereas $d$ is related to the slope i.e. the increase in $J_{s \text { model }}$ for a given increase in VPD. Model parameters $a, b, c$ and $d$ in the response functions were estimated by minimising the residual sum of squares using a Gauss-Newton algorithm. 


\subsection{Statistical analyses}

Although the model is nonlinear we calculated an adjusted $\mathrm{R}^{2}$ in analogy with linear models. Root mean square error (RMSE) is used to characterize model prediction error. When an analysis of variance indicated a significant effect of tree species on a model parameter of interest, a posthoc Tukey HSD test was carried out to assign species to statistically different groups. The relationships between maximum tree water use rates and tree diameter were established by simple linear regression. All statistical analyses were performed with $\mathrm{R}$ version 2.6.2 (R Development Core Team 2008).

\section{Results and discussion}

\subsection{Sap flux densities and environmental controls}

Maximum sap flux densities between 13.2 and $52.1 \mathrm{~g} \mathrm{~cm}^{-2} \mathrm{~h}^{-1}$ were observed in the course of this study. This is in line with values published for tropical forest tree species which are mostly situated between 5 and $50 \mathrm{~g} \mathrm{~cm}^{-2} \mathrm{~h}^{-1}$ (Granier et al. 1996; Meinzer et al. 2001; Dünisch and Morais 2002), although values of up to $70 \mathrm{~g} \mathrm{~cm}^{-2} \mathrm{~h}^{-1}$ have been reported (Becker 1996; O'Brien et al. 2004).

Performance of the model describing sap flux density was quite satisfying, which is illustrated by high $\mathrm{R}^{2}{ }_{\text {adj }}$ values for almost all study trees $\left(\mathrm{R}^{2}\right.$ adj ranged from 0.62 to 0.97 , average 0.92$)$ and low root mean square errors (RMSE, range 0.8 to 6.9 , average $2.0 \mathrm{~g} \mathrm{~cm}^{-2} \mathrm{~h}^{-2}$ ). A visual impression of the agreement between modelled and measured sap fluxes is given for a representative cacao tree in Indonesia (Fig. 1).

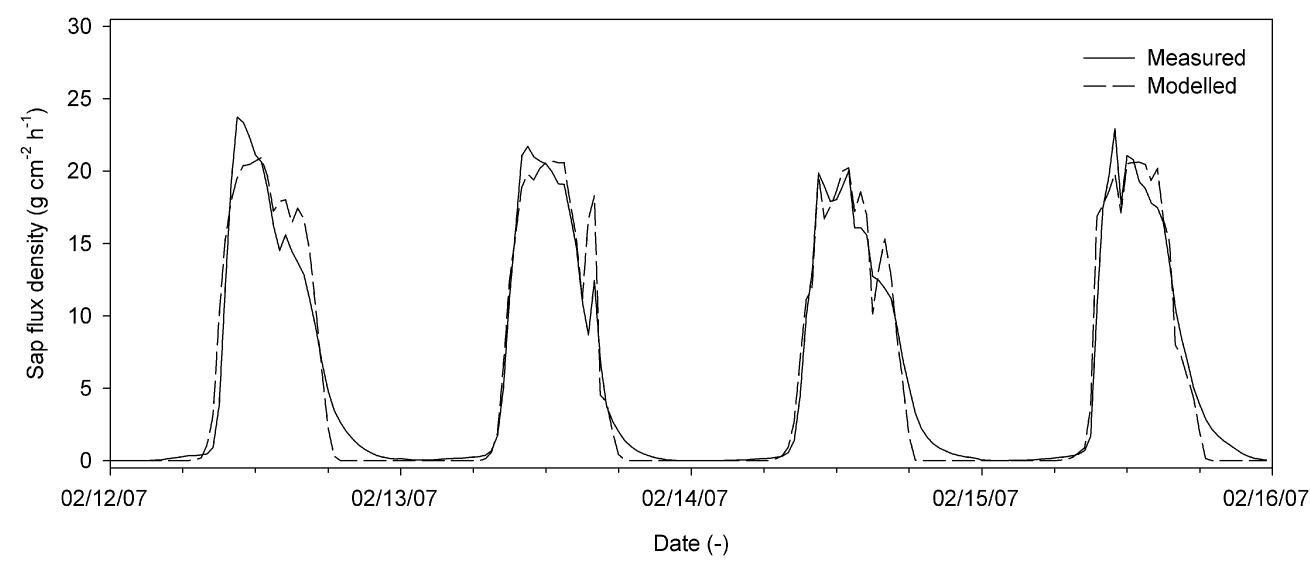

Figure 1: Measured and modelled sap flux in a selected cacao tree (Theobroma cacao) for four days in February 2007, Indonesia. Note that the model form is such that modelled sap flux at night is set to zero. 
Model performance suggests that the model form was appropriate and that vapour pressure deficit and radiation indeed exerted strong influence on sap flux of the trees in the study periods. We acknowledge that at other times of the year this could be different. Especially when rainfall is limited, soil moisture could become more influential as an explanatory variable and the need may arise to include it in the model. In particular under seasonal climatic conditions such as at our Panamanian site, this is expected to be the case. For the three study sites combined, the model parameter $a$ differed threefold among species $\left(14.4 \mathrm{~g} \mathrm{~cm}^{-2} \mathrm{~h}^{-1}\right.$ for Vitex parviflora A. L. Juss and $47.2 \mathrm{~g} \mathrm{~cm}^{-2} \mathrm{~h}^{-1}$ for Anacardium excelsum Beberto \& Balb. ex Kunth) and accurately reflected measured maximal sap flux densities in studied species. Within each of the three study sites significant species-specific differences were observed (Fig. 2). Model parameter $b$, which describes the sap flux response to radiation, differed among species at the Philippine and the Indonesian site, but not among the five species studied in Panama.

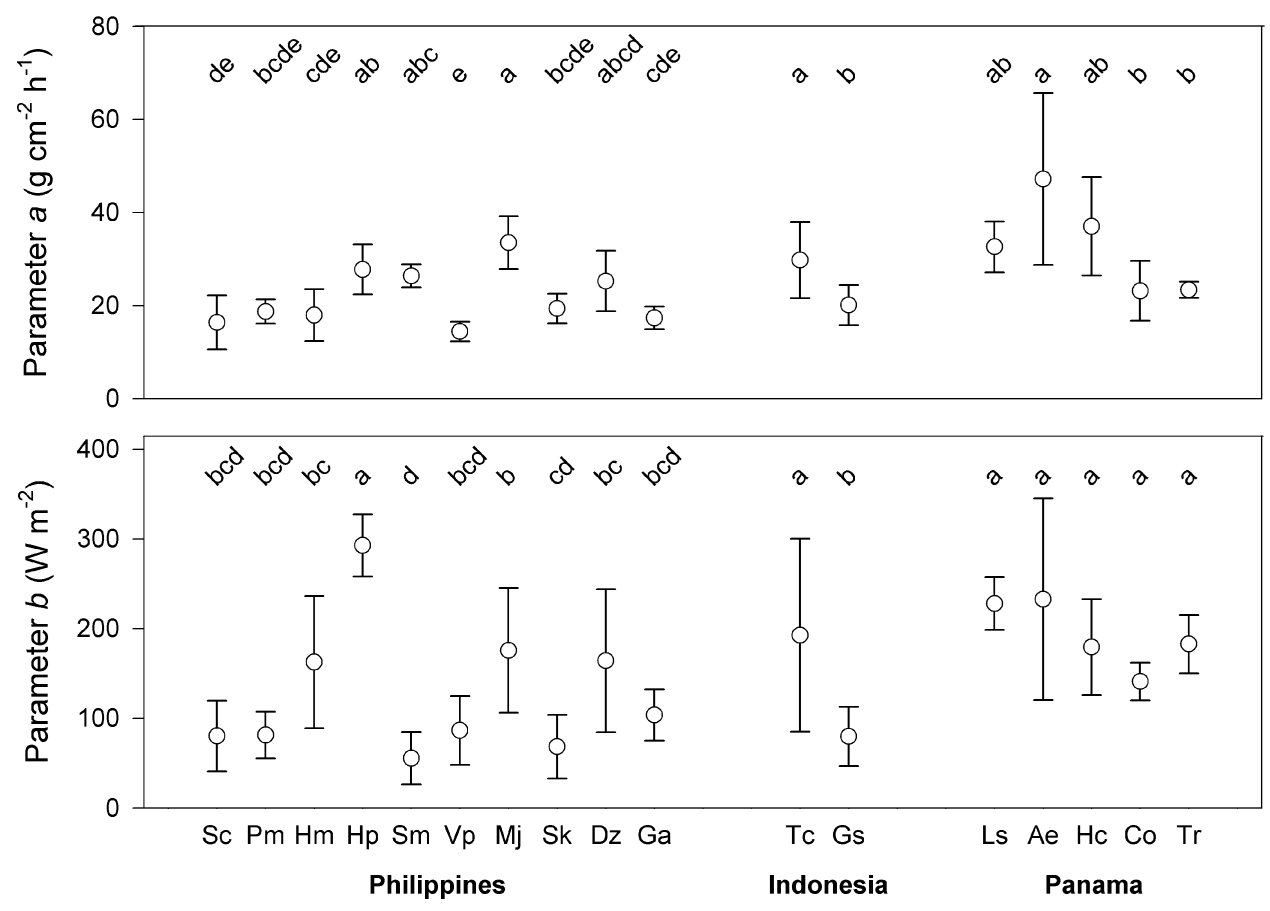

Figure 2: Estimated model parameters $a$ (upper panel) and $b$ (lower panel) for the species studied (means and standard deviations, $\mathrm{n}$ depends on study site (see Table 1$)$ ). Significant differences $(\mathrm{p}<0.05)$ between species within a study site are indicated by different small letters. The complete species names and abbreviations are listed in Table 1.

High values for parameter $b$ were found in species which did not have full sun exposed crowns such as Hopea plagata in the Philippines and Theobroma cacao in Indonesia. A possible explanation is that in trees growing under shade or having a layered crown structure sap flux continues to rise with additional light even at high radiation. 


\subsection{Sap flux density in relation to tree size}

At first view our data suggests, despite a very low $\mathrm{R}^{2}{ }_{\text {adj }}$, a negative relation between maximum sap flux density $J_{\text {max }}$ and tree diameter (Fig. 3). This finding is explained by the significant decline in sap flux density with increasing diameter we observed in the dataset from Indonesia (Fig. 3 inset). Rather than by a real effect of diameter on $J_{s \max }$, the latter is caused by the different diameter range of sampled cacao and Gliricidia trees in combination with the different sap flux densities observed for these species. The complete lack of a diameter-related decline of sap flux density with diameter at the two other study sites supports this interpretation.

The absence of a decline of sap flux density with diameter apparently contradicts the hypothesis of functional convergence (Meinzer et al. 2001; Meinzer et al. 2005). Their work in Panama revealed a strong inverse relationship $\left(\mathrm{R}^{2}=0.85\right)$ between maximum sap flux density and tree diameter in 24 co-occurring species in a Panamanian old-growth forest. Similarly, in a patch of advanced secondary forest in Vietnam, a weak but significant $\left(\mathrm{R}^{2}=0.23\right)$ decline of mean $J_{s}$ with tree diameter existed (Giambelluca et al. 2003).

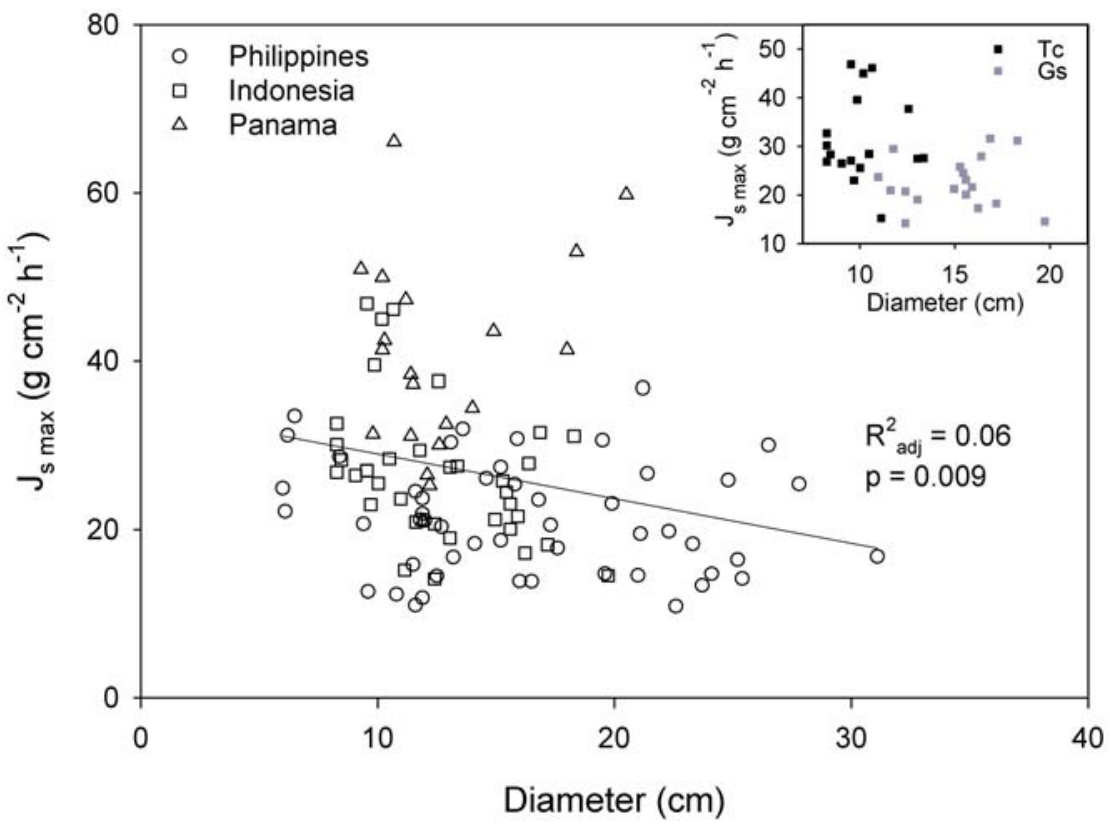

Figure 3: Maximum sap flux density $\mathrm{J}_{\mathrm{s} \text { max }}$ for individual trees in the three studies in relation to tree diameter. The inset shows the data from the Indonesian study site

At the same time however, that study acknowledged the presence of large differences in $J_{s}$ across and within species and the decisive role of factors such as tree exposure and environmental conditions. That our data did not reveal a similar pattern of declining $J_{s \text { max }}$ with tree diameter could be due to the limited diameter range encompassed in comparison with the original 
work (Meinzer et al. 2001). The data presented by Meinzer et al. (2001) revealed considerable scatter, in particular in the lower diameter range where the steepest decline in $J_{\text {smax }}$ is predicted.

A possible implication is that general patterns resulting from functional convergence may remain unnoticed if the range of tree diameters covered is too narrow. In our opinion the species differences we observed in $J_{s \max }$ and responses of $J_{s}$ to environmental variables do not necessarily contradict the hypothesis of functional convergence (Meinzer 2003). We hypothesise that this finding merely reflects that considerable variation remains within general patterns observed across species. This can in part be due to species-specific adaptation to a given set of growth conditions and possibly also due to stand structural differences (see also Cienciala et al. 2000).

In stands where functional convergence can be demonstrated, it would be an essential tool in assessing stand transpiration. This is particularly true in species-rich and highly structured natural forest stands (McJannet et al. 2007). However, we argue functional convergence to be less relevant in relatively young mixed reforestation or agroforest stands characterized by limited diameter ranges and stand structure. In our opinion the species-specific differences in sap flux density we observed in co-occurring trees would become relatively more important under such conditions and become a determining factor for stand water use.

\subsection{Tree water use, tree diameter, and transpiration}

Our data revealed a strong positive correlation between maximum daily tree water use and tree diameter (Fig. 4a). This is true for the pooled data, as well as for data from the individual study sites (Fig. 4b-d). Also Meinzer et al. (2004) found for different co-occurring species in Panama, that tree size rather than tree species was a determining factor for tree water use. Followup studies encompassing more species and replicates revealed similar allometric relationships between tree water use rates and tree diameter (and biomass) that were shared by species belonging to distinct species groups (Meinzer et al. 2005). The relation between tree water use and tree diameter was best described by a sigmoid relationship in 18 mainly tropical angiosperm tree species. That a simple linear regression between tree diameter and tree water use explains most of the variance in our data set, should be seen in relation to the small diameter range covered. Some theoretical relationships describing water use versus tree size characteristics might be inappropriate from a biological point of view, even though they provide an adequate fit in certain datasets (Meinzer et al. 2005). The same appears to be the case in our study. 

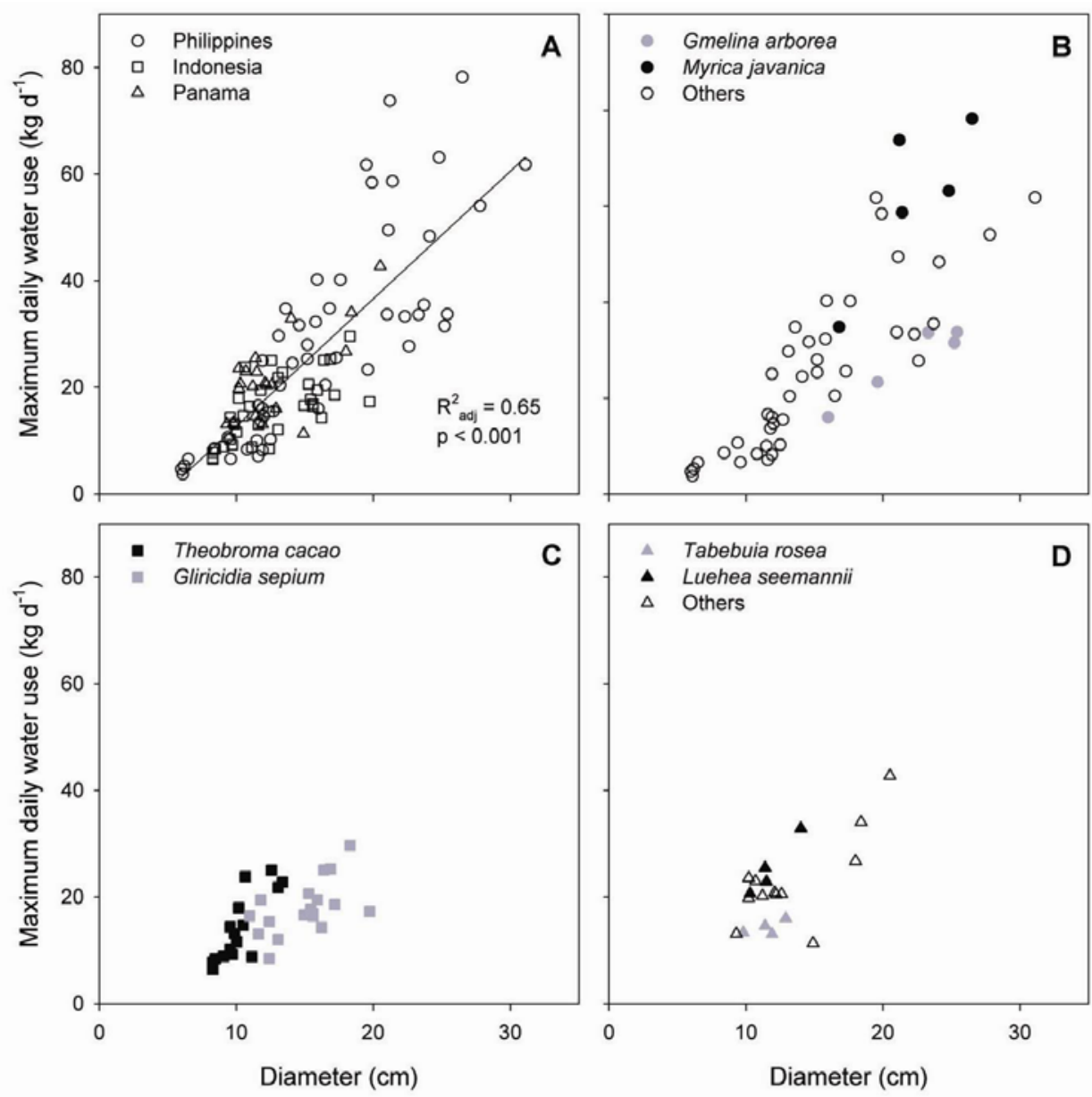

Figure 4: Maximum daily water use rates $Q_{\max }$ for each individual in relation to tree diameter for all studied trees (a). Analogue plots show the data for species in the Philippines (b), Indonesia (c) and Panama (d). In each of the latter graphs two contrasting species are shown with a different symbol.

Despite the strong dependence of maximum water use on diameter for the individuals studied, considerable scatter was present around the fitted curve with species located on distinct trajectories (Fig. 4b-d). For a given tree diameter, tree water use differed up to twofold between some of the species studied. This resulted from a combination of both species-specific $J_{s}$ and species differences in hydroactive xylem depth. Apart from these factors, the relationship would be determined strongly by cross correlation between estimated water use rates and tree diameter. This can be expected to be most pronounced in the lower diameter ranges (Meinzer et al. 2001), making the deviations from a common relationship even more significant. Maximum transpiration rates observed in individual trees varied from 0.4 to $4.9 \mathrm{~mm} \mathrm{~d}^{-1}$, except for a single individual of Swietenia macrophylla King which had a maximum transpiration rate of $7.5 \mathrm{~mm} \mathrm{~d}^{-1}$. A small crown projection area and associated larger relative error in this individual could explain the high value. Excluding this single tree, results are comparable with findings from Giambelluca et al. (2003) who measured daily transpiration rates in individual trees from 0.5 to $4.6 \mathrm{~mm} \mathrm{~d}^{-1}$ in a patch of advanced secondary forest in Vietnam during the wet season. In our study, mean transpiration 
rates over the study periods differed fourfold across species from 0.6 to $2.4 \mathrm{~mm} \mathrm{~d}^{-1}$ (Table 2). For the mentioned study in a forest patch in Vietnam, transpiration rates were also found to be different among species and were, in addition, influenced by crown exposure, seasonality and enhanced transpiration at the forest edge (Giambelluca et al. 2003). It is unlikely that differences in transpiration rates observed between species can be translated directly to transpiration at the stand level as different stand development and stand structure of contrasting species (or species mixtures) are likely to partly reduce species-specific transpiration rates. Nevertheless, we assume that the remarkable differences across tree species in both tree water use and tree transpiration rates could be exploited to manage stand water use.

Table 2: Maximum $\left(Q_{\text {max }}\right)$ and mean water use $\left(Q_{\text {mean }}\right)$ and maximum $\left(T_{\text {max }}\right)$ and mean $\left(T_{\text {mean }}\right)$ transpiration rates (means and standard deviations, $\mathrm{n}$ depends on study site (see Table 1$)$ ). Significant differences $(\mathrm{p}<0.05)$ are indicated by different small letters.

\begin{tabular}{|c|c|c|c|c|c|c|c|c|c|c|}
\hline \multirow[t]{2}{*}{ Species } & \multicolumn{2}{|c|}{$\begin{array}{r}Q_{\max } \\
\left(\mathrm{kg} \mathrm{d}^{-1}\right)\end{array}$} & \multicolumn{2}{|c|}{$\underset{\left(\mathrm{kg} \mathrm{d}^{-1}\right)}{\mathcal{Q}_{\text {mean }}}$} & \multicolumn{3}{|c|}{$\begin{array}{c}\mathrm{T}_{\max } \\
\left(\mathrm{mm} \mathrm{d}^{-1}\right)\end{array}$} & \multicolumn{3}{|c|}{$\begin{array}{c}\mathrm{T}_{\text {mean }} \\
\left(\mathrm{mm} \mathrm{d}^{-1}\right)\end{array}$} \\
\hline & Mean & SD & Mean & $\mathrm{SD}$ & Mean & & SD & Mean & & SD \\
\hline Shorea contorta & 25.6 & 19.5 & 18.4 & 14.4 & 2.03 & abcd & 0.93 & 1.45 & $\mathrm{abc}$ & 0.70 \\
\hline Parashorea malaanonan & 15.3 & 1.2 & 10.6 & 1.1 & 1.24 & bed & 0.28 & 0.85 & bc & 0.17 \\
\hline Hopea malibato & 13.1 & 8.5 & 9.1 & 6.7 & 1.33 & bed & 0.43 & 0.89 & be & 0.29 \\
\hline Hopea plagata & 5.7 & 1.9 & 4.0 & 1.3 & 0.85 & ed & 0.18 & 0.59 & bc & 0.12 \\
\hline Swietenia macrophylla & 33.7 & 4.1 & 25.5 & 3.6 & 3.14 & a & 2.46 & 2.38 & a & 1.90 \\
\hline Vitex parviflora & 30.7 & 14.6 & 20.7 & 9.3 & 1.02 & bed & 0.32 & 0.69 & bc & 0.20 \\
\hline Myrica javanica & 61.7 & 17.0 & 43.2 & 12.5 & 2.60 & ab & 0.60 & 1.80 & $a b$ & 0.38 \\
\hline Sandoricum koetjape & 32.8 & 16.5 & 23.4 & 12.6 & 1.90 & abcd & 0.98 & 1.36 & abc & 0.77 \\
\hline Durio zibethinus & 44.7 & 18.5 & 32.9 & 14.8 & 1.52 & abcd & 0.81 & 1.11 & bc & 0.62 \\
\hline Gmelina arborea & 27.6 & 7.8 & 19.8 & 6.1 & 1.67 & abcd & 0.46 & 1.18 & abc & 0.32 \\
\hline Theobroma cacao & 13.4 & 6.2 & 10.0 & 4.5 & 0.63 & cd & 0.35 & 0.47 & c & 0.25 \\
\hline Gliricidia sepium & 17.9 & 5.0 & 13.9 & 4.1 & 0.54 & d & 0.36 & 0.42 & c & 0.28 \\
\hline Luehea seemannii & 25.5 & 5.3 & 13.1 & 3.6 & 2.14 & abcd & 0.26 & 1.11 & be & 0.22 \\
\hline Anacardium excelsum & 19.8 & 4.8 & 10.5 & 2.8 & 2.64 & ab & 1.58 & 1.37 & abe & 0.79 \\
\hline Hura crepitans & 28.7 & 13.3 & 14.6 & 7.6 & 2.01 & abcd & 0.38 & 1.01 & bc & 0.23 \\
\hline Cedrela odorata & 20.5 & 0.3 & 9.9 & 2.2 & 2.34 & abc & 0.74 & 1.09 & bc & 0.29 \\
\hline Tabebuia rosea & 14.2 & 1.4 & 7.9 & 0.6 & 1.09 & bcd & 0.27 & 0.60 & bc & 0.11 \\
\hline
\end{tabular}

\section{Conclusions}

We conclude that water use- and transpiration rates found in trees of tropical reforestation and agroforestry stands showed considerable variation across species. Despite the strong dependence of maximal tree water use on tree diameter for the individuals studied, considerable scatter was present around the fitted curve with species located on distinct trajectories. At a given diameter, up to twofold differences between trees of different species were observed. Species selection might thus indeed be an effective tool to control water use in reforestation and agroforestry. It can be used to optimise the balance between wood production or carbon sequestration and the use of water resources.

\section{Acknowledgements}

This study was funded by the German Research Foundation in the framework of the SFB 552 (sub-project B4) and a further grant for the study in Panama (Ho-2119/3-1). 


\section{References}

Becker P (1996) Sap flow in Bornean heath and dipterocarp forest trees during wet and dry periods. Tree Physiology 16: 295-299

Cienciala E, Kucera J, Malmer A (2000) Tree sap flow and stand transpiration of two Acacia mangium plantations in Sabah, Borneo. Journal of Hydrology 236: 109-120

Dierick D, Hölscher D (2009) Species-specific tree water use characteristics in reforestation stands in the Philippines. Agricultural and Forest Meteorology 149: 1317-1326

Dünisch O, Morais RR (2002) Regulation of xylem sap flow in an evergreen, a semi-deciduous, and a deciduous Meliaceae species from the Amazon. Trees-Structure and Function 16: 404-416

Farley KA, Jobbagy EG, Jackson RB (2005) Effects of afforestation on water yield: a global synthesis with implications for policy. Global Change Biology 11: 1565-1576

Giambelluca TW, Ziegler AD, Nullet MA, Truong DM, Tran LT (2003) Transpiration in a small tropical forest patch. Agricultural and Forest Meteorology 117: 1-22

Gradstein SR, Kessler M, Pitopang R (2007) Tree species diversity relative to human land uses in tropical rain forest margins in Central Sulawesi. In: Tscharntke T, Leuschner C, Guhardja E, Zeller M (Eds.), The Stability of Tropical Rainforest Margins: Linking Ecological, Economic and Social Constraints of Land Use and Conservation. Springer, Berlin, p. 321-334

Granier A (1985) A new method of sap flow measurement in tree stems. Annals of Forest Science 42: 193-200

Granier A (1987) Evaluation of transpiration in a Douglas-fir stand by means of sap flow measurements. Tree Physiology 3: 309-319

Granier A, Huc R, Barigah ST (1996) Transpiration of natural rain forest and its dependence on climatic factors. Agricultural and Forest Meteorology 78: 19-29

Granier A, Loustau D, Breda N (2000) A generic model of forest canopy conductance dependent on climate, soil water availability and leaf area index. Annals of Forest Science 57: 755-765

Harris PP, Huntingford C, Cox PM, Gash JHC, Malhi Y (2004) Effects of soil moisture on canopy conductance of Amazonian rainforest. Agricultural and Forest Meteorology 122: 215-227

Hatton TJ, Catchpole EA, Vertessy RA (1990) Integration of sapflow velocity to estimate plant water-use. Tree Physiology 6: 201-209

Herbst M, Eschenbach C, Kappen L (1999) Water use in neighbouring stands of beech (Fagus sylvatica L.) and black alder (Alnus glutinosa (L.) Gaertn.). Annals of Forest Science 56: 107-120

Jackson BJ, Jobbagy EG, Avissar R, Roy SB, Barrett DJ, Cook CW, Farley KA, le Maitre DC, McCarl BA, Murray BC (2005) Trading water for carbon with biological carbon sequestration. Science 310: 1944-1947

Jarvis PG (1976) The interpretation of the variations in leaf water potential and stomatal conductance found in canopies in the field. Philosophical Transactions of the Royal Society of London B- Biological Sciences 273: 593610

Köhler, M., Dierick, D., Schwendenmann, L., Hölscher, D., 2009. Water use characteristics of cacao and Gliricidia trees in an agroforest in Central Sulawesi, Indonesia, Ecohydrology 2, 520 - 529 
Langenberger G (2006) Habitat distribution of dipterocarp species in the Leyte Cordillera: an indicator for speciessite suitability in local reforestation programs. Annals of Forest Science 63: 149-156

Leigh EG, Rand AS, Windsor DW (1996) The ecology of a tropical forest, 2nd edn, Smithsonian Press, Washington, DC

Margraf J, Milan PP (1996) Ecology of dipterocarp forests and its relevance for island rehabilitation in Leyte, Philippines. In: Schulte A, Schöne D (Eds.), Dipterocarp Forest Ecosystems: Towards Sustainable Management. World Scientific, Singapore, p. 124-154

McJannet D, Fitch P, Disher M, Wallace J (2007) Measurements of transpiration in four tropical rainforest types of north Queensland, Australia. Hydrological Processes 21: 3549-3564

Meinzer FC (2003) Functional convergence in plant responses to the environment. Oecologia 134: 1-11

Meinzer FC, Goldstein G, Andrade JL (2001) Regulation of water flux through tropical forest canopy trees: Do universal rules apply? Tree Physiology 21: 19-26

Meinzer FC, James SA, Goldstein G (2004) Dynamics of transpiration, sap flow and use of stored water in tropical forest canopy trees. Tree Physiology 24: 901-909

Meinzer FC, Bond BJ, Warren JM, Woodruff DR (2005) Does water transport scale universally with tree size? Functional Ecology 19: 558-565

O'Brien JJ, Oberbauer SF, Clark DB (2004) Whole tree xylem sap flow responses to multiple environmental variables in a wet tropical forest. Plant, Cell and Environment 27: 551-567

Oren R, Pataki DE (2001) Transpiration in response to variation in microclimate and soil moisture in southeastern deciduous forests. Oecologia 127: 549-559

PAGASA (2007) Philippine Atmospheric, Geophysical and Astronomical Services Administration, Philippines.

R Development Core Team (2008) R: A language and environment for statistical computing. R Foundation for Statistical Computing, Vienna, Austria, ISBN 3-900051-07-0,http://www.R-project.org (last visited 28/05/2009)

STRI (2009) Temperature and rainfall data Barro Colorado Island, Panama 1987-2006. http://striweb.si.edu/esp/ physical_monitoring/download_bci.htm (last visited 28/05/2009)

van Dijk AIJM, Keenan RJ (2007) Planted forests and water in perspective. Forest Ecology and Management 251: 19

van Kanten R, Vaast P (2006) Transpiration of arabica coffee and associated shade tree species in sub-optimal, lowaltitude conditions of Costa Rica. Agroforestry Systems 67: 187-202

Whitley R, Zeppel M, Armstrong N, Macinnis-Ng C, Yunusa I, Eamus D (2008) A modified Jarvis-Stewart model for predicting stand-scale transpiration of an Australian native forest. Plant and Soil 305: 35-47 



\title{
Throughfall reduction in a cacao agroforest: tree water use and soil water budgeting
}

\author{
Michael Köhler*, Luitgard Schwendenmann ${ }^{1} \&$ Dirk Hölscher
}

Tropical Silviculture and Forest Ecology, Burckhardt Institute, Georg-August-Universität Göttingen, Büsgenweg 1, 37077 Göttingen, Germany

${ }^{1}$ Present address: School of Environment, The University of Auckland, Private Bag 92019, Auckland 1142, New Zealand

\begin{abstract}
In a cacao agroforest with Gliricidia shade trees we studied the effects of experimentally reduced throughfall on tree sap flux densities and soil water budget. The objectives of our study were: (1) to identify the response of cacao and Gliricidia sap flux densities to reduced soil water availability, and (2) to analyze the changes in stand level soil water partitioning, measured as changes in transpiration, drainage and soil moisture storage under reduced throughfall. The study was conducted in Sulawesi, Indonesia at a site where ambient precipitation was $2841 \mathrm{~mm} \mathrm{yr}^{-1}$. The research site was subdivided into three control plots and three plastic roof plots in which net precipitation was reduced by $71 \%$ through the use of a sub-canopy roof for 13 months, to create rainfall conditions similar to an extended El Niño event. The two species differed in their sap flux response to declining soil water content. Daily Gliricidia sap flux declined at higher soil water contents than cacao, while Gliricidia sap flux declined in response to all levels of vapor pressure deficit (VPD) and cacao only responded to high levels of VPD. Average monthly sap flux densities of cacao and Gliricidia in the roof plots decreased linearly with decreasing soil water content reaching a maximum reduction of $21 \%$ (cacao) and $29 \%$ (Gliricidia) as compared to control plots. Cacao withdrew water mainly from the topsoil where small amounts of throughfall entering gaps in the roof frequently rewetted the soil. Therefore the competition between the two species for water resources during long periods with only little precipitation was low or in favor of cacao. Average daily stand transpiration was $1.3 \mathrm{~mm}$ in roof plots and $1.5 \mathrm{~mm}$ in control plots. Measured soil water contents were simulated satisfactorily by the application of a one-dimensional soil water model based on Richards unsaturated flow equation. The model suggested that drainage amounted to $1554 \mathrm{~mm} \mathrm{yr}^{-1}$ in control plots. Drainage in roof plots was greatly reduced, totaling $299 \mathrm{~mm} \mathrm{yr}^{-1}$. Soil moisture storage in the control underwent minor variations while it was heavily reduced in roof plots. Drainage in roof plots was a large driver of changes in soil moisture storage especially in deeper soil layers while precipitation and root water uptake were the main influencing factors for the topsoil. Deep root water uptake seemed to play a minor role in this experiment. Despite the strong reduction in net precipitation, declines in stand transpiration were moderate, suggesting that the stand did not react sensitively to the reduced throughfall scenario.
\end{abstract}

Keywords: drainage, transpiration, Gliricidia sepium, Indonesia, sap flux density, Theobroma cacao

Received 6 January 2010, Accepted 8 April 2010

*Corresponding author. Tel.: +49 551 399556; Fax: +49 551 394019; E-mail address: mkoehle1@gwdg.de 


\section{Introduction}

Agroforestry is an important land use option in the human dominated landscapes of the tropics. Agroforestry practices contribute to the conservation of biodiversity (Leakey, 1999) and could potentially contribute to the mitigation of climate change through enhanced carbon storage (Verchot et al., 2007). Furthermore, studies indicate that agroforests exhibit improved resilience to reduced precipitation as trees draw water from deeper soil layers while providing shade to main crops (Verchot et al., 2007). Resilience to drought may become increasingly important in tropical regions as climate change studies predict that these regions could experience a shift in precipitation patterns leading to more frequent and/or more severe droughts in the future (Sheffield and Wood, 2008). The assessment of ecosystem water budgets and changes in plant water use under reduced precipitation regimes is important because both contribute to the prediction of specific ecosystem responses to climate change and provide insight which may be useful to improve future watershed modeling as well as studies of soil nutrient cycles.

One method to study changes in forest ecosystem water budgets and plant water use caused by reduced rainfall is the reduction or exclusion of canopy throughfall to artificially impose dry conditions on selected plots. Such stand level approaches are advantageous over studies on water limitations of pot grown plants or saplings because questions of individual plant response, interactions between plants, and stand level water carbon and nutrient cycling responses can be handled here (Hanson, 2000). Large scale water manipulation experiments have been conducted in temperate grasslands (Fay et al., 2000) but also in forest ecosystems (Gebre et al., 1998; Hanson et al., 1998). In some manipulation experiments roofs were constructed intercepting $100 \%$ of throughfall (Fay et al., 2000; Bredemeier et al., 1998) and desired quantities and qualities of water were supplied by irrigation.

Also frequently applied is the partial coverage of the ground area with gutters or troughs (Hanson et al., 1998) to reduce incoming throughfall. Two stand level throughfall manipulation experiments of this kind have already been conducted to study plant and whole ecosystem responses towards reduced throughfall in the tropical rainforests, namely in East-Central (Nepstad et al., 2002; Belk et al., 2007) and Eastern Amazonia (Fisher et al., 2007). A soil water model applied to the East-Central Amazonian rainforest suggested only a mild transpiration decline after two years of throughfall reduction. However, no data on tree water use characteristics were surveyed to confirm these findings. Such measurements were conducted in the Eastern Amazon and a strong sap flux decline was found (Fisher et al., 2007). 
Nonetheless, the way in which man made vegetation types like agroforests react to changing precipitation patterns is still unclear since hydrological regimes are expected to undergo large changes when rainforests are converted (Bruijnzeel, 1996). These effects may be attributed to specific interception characteristics of the planted vegetation (see Zhang et al., 1999), to differences of water use characteristics of planted exotic trees compared to native species, but also to the specific stand structure of planted forests like the limited diameter range of trees and the homogenous layout of the stands. For example, a clear species effect on plant water use was found for young agroforestry and reforestation stands in Indonesia, Panama and the Philippines (Dierick et al., 2010), while water use in old growth forests depended on tree size and not on species identity (Meinzer et al., 2003; Meinzer et al., 2005). Management practices and species choice also influence the interaction of associated species in agroforests, i.e. complementary use of water or competition for it (Schroth, 1999).

In Indonesia rainforest conversion to agroforestry is of great import. Although Indonesia is the third largest cacao producer in the world (ICCO, 2009) and shows high risk for damaging droughts attributed to El Niño (Quinn et al., 1978), there is little information available about the effects of water deficits on cacao/shade tree ecosystems from this region or even from other countries. Modeling studies have indicated up to 50\% reduced transpiration during dry seasons (Radersma and de Ridder, 1996) and a strong positive correlation between yield and rainfall (Zuidema et al., 2005). Studies focusing on the water relations of cacao seedlings (e.g. Joly and Hahn, 1998) or leaves (Balasimha et al., 1991) have found effective stomatal control of transpiration under water stress but it remains unclear whether these findings can be extrapolated to the stand level. No other field study thus far has assessed ecosystem level responses to drought in cacao agroforests as far as we are aware.

In previous work, sap flux densities and water use characteristics of a cacao/Gliricidia agroforest in Central Sulawesi, Indonesia were studied under ambient soil moisture conditions employing heat dissipation sap flux gauges (Köhler et al., 2009). Sap flux and water use of trees in this stand were found to be similar to values reported for trees of similar age and size in the tropics. This data provided a starting point for the present study in which we imposed rainfall conditions similar to an extended El Niño event on three experimental plots in the same stand by diverting throughfall with large sub-canopy roofs for 13 months (Schwendenmann et al., 2010) and compared the tree sap flux in these roof plots to sap flux in three untreated control plots. We further incorporated estimates of stand transpiration, volumetric soil water content from the rooting zone and net precipitation into a one-dimensional soil water transport model to calculate the remaining components of the soil water budget and the temporal distribution of soil water 
storage change and drainage. The model will also be applied for companion studies on nutrient cycling and $\mathrm{CO}_{2}$ leaching flux conducted in this agroforestry system.

The objectives of our study were: 1) to identify the response of cacao and Gliricidia sap flux densities to reduced soil water availability, and 2) to analyze the changes in stand level soil water partitioning, measured as changes in transpiration, drainage and soil moisture storage under reduced throughfall. Our study may help to better understand the response of tree-based land use systems in the tropics to extended droughts which may become more frequent and more severe in the future due to climate change.

\section{Methods}

\section{Study site}

The study was conducted in a seven year old cacao/Gliricidia agroforest at $560 \mathrm{~m}$ a.s.l. on a mild slope (8-12 ${ }^{\circ}$ inclination) close to the village of Marena in the district of Bolapapu, in Central Sulawesi, Indonesia $\left(1.552^{\circ} \mathrm{S}, 120.020^{\circ} \mathrm{E}\right)$. Data from a nearby weather station (Gimpu, $5 \mathrm{~km}$ south of Marena at $471 \mathrm{~m}$ a.s.l.) collected between 2002 and 2006 showed an average annual temperature of $25.5^{\circ} \mathrm{C}$ and an annual precipitation of $2092 \mathrm{~mm} \mathrm{y}^{-1}$ (Kreilein, Panferov \& Gravenhorst, unpublished data) with no distinct dry season. Leaf area index for the cacao tree layer was estimated at $3.8 \mathrm{~m}^{2} \mathrm{~m}^{-2}$ and for the shade trees in the stand at $1.3 \mathrm{~m}^{2} \mathrm{~m}^{-2}$ (Schwendenmann et al., 2010). The water table at the site was below $4.5 \mathrm{~m}$ depth as estimated with piezometers. The soil was classified as a Cambisol with sandy loam texture and high rock fragment content in the subsoil (Leitner \& Michalzik, unpublished data). Main soil characteristics are listed in Table 1.

Table 1: Average soil texture, bulk density and rock content (mean $\pm \mathrm{SD}, \mathrm{n}=6$, no significant differences between roof and control).

\begin{tabular}{|c|c|c|c|c|c|c|}
\hline $\begin{array}{l}\text { Depth } \\
(\mathrm{cm})\end{array}$ & $\begin{array}{c}\text { Sand } \\
\text { (vol. \%) }\end{array}$ & $\begin{array}{c}\text { Silt } \\
\text { (vol. \%) }\end{array}$ & $\begin{array}{c}\text { Clay } \\
\text { (vol. \%) }\end{array}$ & $\begin{array}{l}\text { Bulk density } \\
\qquad\left(\mathrm{g} \mathrm{cm}^{-3}\right)\end{array}$ & $\begin{array}{l}\text { Depth } \\
(\mathrm{cm})\end{array}$ & $\begin{array}{c}\text { Rock content } \\
\text { (vol. \%) }\end{array}$ \\
\hline $0-10$ & $55.0 \pm 3.4$ & $29.7 \pm 3.6$ & $15.3 \pm 2.4$ & $1.28 \pm 0.04$ & $0-50$ & $7.9 \pm 3.0$ \\
\hline $10-20$ & $55.7 \pm 0.9$ & $28.2 \pm 3.0$ & $16.1 \pm 3.5$ & $1.31 \pm 0.02$ & $50-100$ & $19.0 \pm 4.3$ \\
\hline $20-40$ & $53.9 \pm 4.8$ & $26.5 \pm 3.3$ & $18.6 \pm 2.9$ & $1.32 \pm 0.05$ & $100-150$ & $20.9 \pm 2.4$ \\
\hline $40-75$ & $57.9 \pm 2.3$ & $22.8 \pm 3.4$ & $19.3 \pm 3.3$ & $1.37 \pm 0.09$ & $150-200$ & $26.7 \pm 8.8$ \\
\hline $75-150$ & $68.7 \pm 5.3$ & $19.4 \pm 3.0$ & $11.9 \pm 4.4$ & $1.52 \pm 0.10$ & $200-250$ & $24.1 \pm 5.4$ \\
\hline $150-250^{a}$ & $70.3 \pm 7.1$ & $22.8 \pm 6.4$ & $6.9 \pm 2.3$ & $1.60 \pm 0.06$ & & \\
\hline
\end{tabular}

Cacao trees (1030 stems ha ${ }^{-1}$ ) grew under a cover of Gliricidia sepium (Jacq.) Kunth ex Steud shade trees $\left(325\right.$ stems $^{-1}{ }^{-1}$ ). Average tree height was 5.4 and $9.5 \mathrm{~m}$ for cacao and Gliricidia, re- 
spectively. Throughout the study period, cacao trees were pruned in July and December of 2007, while Gliricidia trees were not pruned. The ground was kept free of an herbaceous understory due to low light availability below the canopy supplemented by regular weeding.

\section{Experimental design}

The study stand ( $\sim 1$ ha) was subdivided into three throughfall reduction 'roof plots' and tree control plots. Each plot measured $40 \mathrm{~m} \times 35 \mathrm{~m}$ and all measurements were conducted in a central 'core zone' $(30 \times 25 \mathrm{~m})$ within each plot to avoid edge effects from the surrounding area. The plots were separated by trenches extending over the main rooting zone $(40 \mathrm{~cm})$ lined with plastic in order to obstruct lateral water movement, root water uptake from the surrounding and the intrusion of overland flow. The roof plots were covered with large sub-canopy roofs made from polyethylene foil lined bamboo frames covering approximately $80 \%$ of the total ground area. The roof extended below the branching point of cacao $(\sim 100 \mathrm{~cm}$ above ground).

Measurements were taken continuously from February 1, 2007 to June 5, 2008. The roofs were set up on March 1, 2007 and were operated subsequently for 13 months until April 10, 2008 when the throughfall reduction experiment was discontinued. This time span allowed the recording of a baseline dataset before the initiation of throughfall reduction and also allowed for the assessment of data within the rewetting phase after opening the roof. The percentage throughfall reduction ranged from 48 to 59\% in March and April 2007 and increased to 78\% from May 2007 onwards (Moser et al., in press). For a detailed description of this experiment see Schwendenmann et al. (2010).

\section{Micrometeorological and soil water content measurements}

Data on air humidity and air temperature (CS215, Campbell Scientific Inc., Logan, UT, USA), global radiation ( $R_{g}$, CS300, Apogee Instruments Inc., Logan, UT, USA) and precipitation (ARG100, Environmental Measurements Ltd., Sunderland, UK) were gathered at a distance of $30 \mathrm{~m}$ from the study stand and at a height of $4 \mathrm{~m}$. Data was collected every 5 seconds, averaged and logged at 30 min intervals using a CR800 data logger (Campbell Scientific Inc., Logan, UT,USA). Measured global radiation values indicated that the sensor underestimated real values from October 2007 onward due to malfunctioning. We therefore did not include global radiation in the analyses of sap flux.

Volumetric soil water content was measured in the study site with time domain reflectrometry probes (TDR, CS616, Campbell Scientific Inc., Logan, UT). On each plot one large soil pit $(80 \times 160 \times 300 \mathrm{~cm})$ was dug and TDR sensors were placed at depths of 10, 20, 40, 75, 150 and 
$250 \mathrm{~cm}$. Two additional sensors were installed at depths of $10 \mathrm{~cm}$ and $75 \mathrm{~cm}$ in two smaller soil pits $(80 \times 100 \times 250 \mathrm{~m})$ in each plot. The pit walls where TDRs were installed were covered with plastic foil to prevent evaporation. Because TDR installation was hindered by high rock fragment content at greater depths, only two roof and control plots carried TDRs at $150 \mathrm{~cm}$. Additionally, TDRs could only be installed at $250 \mathrm{~cm}$ in two control plots and one roof plot. The probes were calibrated following Veldkamp and O'Brien (2000) using two samples from depths of 10, 40 and $70 \mathrm{~cm}$. As differences in calibration curves between depths were minimal, one lumped calibration was applied to TDRs at 10, 20, 40 and $75 \mathrm{~cm}$ depth (for details see Köhler et al., 2009). TDRs at 150 and $250 \mathrm{~cm}$ depth could not be calibrated because large rock fragments prevented the extraction of undisturbed soil samples. In substitution, the manufacturer's calibration was applied here. Data was logged hourly using a CR1000 data logger (Campbell Scientific Inc., Logan, UT)

Care was taken to install the TDRs where there were no rock fragments. However, the rock fragments remaining in the soil caused an overestimation of soil water storage due to the fact that rock fragments do not hold (plant available) water. To correct for this overestimation all measured volumetric water contents were proportionally reduced to the actual volume of soil that was not occupied by rock fragments ( Fiès et al., 2002). The total volume of rock fragments in the soil was estimated in soil layers between the depths of 50 and $250 \mathrm{~cm}$ in one pit per plot (Table 1). Rock fragments were excavated, cleaned, sun-dried and weighed. Rock volume was calculated from an estimate of rock bulk density which was derived from the weight and water displacement of a sub sample of rock fragments. The measured volumetric soil water contents at $10,20,40,75$ and $250 \mathrm{~cm}$ depth were then corrected using the rock fragment contents from the respective layers. For the water content measured at $150 \mathrm{~cm}$ depth we used the average rock fraction of the 100-150 and 150-200 cm layers.

\section{Sap flux density and tree water use}

In each plot we equipped three randomly selected cacao and three Gliricidia trees with two heat dissipation sap flux sensors constructed after Granier (1987). In Gliricidia trees, sensors were placed at $130 \mathrm{~cm}$ height and in cacao trees below the branching point at around $60-100 \mathrm{~cm}$ above the ground. The diameter measured between the upper and the lower probe and the height (mean $\pm \mathrm{SD}$ ) of the selected trees were $10.1 \pm 1.6 \mathrm{~cm}$ and $4.5 \pm 0.8 \mathrm{~m}$ for cacao and $15.0 \pm 2.5 \mathrm{~cm}$ and $10.9 \pm 2.1 \mathrm{~m}$ for Gliricidia, respectively.

Each sap flux sensor consisted of a pair of probes $2.4 \mathrm{~cm}$ in lengths which were inserted at $14 \mathrm{~cm}$ vertical distance into the trunks of selected trees. Sensors were shielded by a box made from insulating Styrofoam and a section of the stem extending well above and below the sensors 
was covered by reflective foil to limit temperature gradients caused by incident solar radiation. The temperature difference between the upstream and the heated downstream probes was recorded every $30 \mathrm{~s}$ and averaged and stored every $30 \mathrm{~min}$ (CR1000 data logger and AM 16/32 multiplexer, Campbell Scientific Inc., Logan, UT, USA.). Temperature differences were converted to sap flux density $\left(J_{s}, \mathrm{~g} \mathrm{~cm}^{-2} \mathrm{~h}^{-1}\right)$ employing an empirically derived equation Granier (1987).

The reduction of sap flux density with increasing xylem depth was further assessed in eight trees per species after xylem area was estimated by dye injection. Thereby, sap wood depth was found to be greater than sensor length. Sap flux density measured at each xylem depth was multiplied by the respective xylem area to calculate water use rates for each depth. These were then summed to yield the total tree water use $Q\left(\mathrm{~kg} \mathrm{~d}^{-1}\right)$.

For each species in the roof and control plots we established daily regressions between $Q$ and tree diameter $(n=9)$. These relationships were used to calculate $\mathcal{Q}$ for all other individuals present in the stand based on measured tree diameters. Summing all tree water use rates and dividing this sum by the ground area of the respective plots yielded stand transpiration $\left(T, \mathrm{~mm} \mathrm{day}^{-1}\right)$. The sap flux measurements collected from three individuals per species per plot were used to derive $T$ for the entire stand. As tree and row spacing was regular, the plot margins were located just in between two rows of trees wherefore the ground area of each plot was well defined. Therefore the error margin of the transpiration estimates was mainly associated to errors of sap flux measurements. During the measurement campaign, we replaced the sensors once in September 2007 which led to missing data within that month. We therefore established a multiple linear regression model between global radiation $\left(R_{g}\right)$, vapor pressure deficit (VPD) and $T$ of roof and control plots using data from August $2007\left(\mathrm{R}^{2}=0.84-0.87, \mathrm{p}<0.05\right)$ and derived $T$ from $\mathrm{R}_{g}$ and VPD for September with this model. Further details on sap flux measurements, water use and transpiration calculations within this stand are described in Köhler et al. (2009).

A difference in sap flux density at a given atmospheric demand is attributed to limited soil water availability if two periods (treatments) with clearly different soil water contents can be distinguished (Pataki et al., 2000). We therefore separated our study period into monthly subperiods and compared the response of cacao and Gliricidia daily integrated sap flux densities to average daily VPD under given soil moisture conditions using nonlinear regression models. Differences between roof and control plots were tested with F-tests comparing a null model comprising lumped data from both treatments per species with alternative models for each of the treatments. 
We further defined a monthly reduction coefficient of sap flux density $\left(J_{s}\right.$ reduction, \%) similar to the approach used by Kume et al. (2007) describing the proportional reduction of $J_{s}$ in roof plots as compared to control plots:

$J_{s}$ reduction $=\left(1-\frac{1}{n} \sum_{i=1}^{n} \frac{f\left(\mathrm{VPD}_{\text {roof }}\right)_{i}}{f\left(\mathrm{VPD}_{\text {control }}\right)_{i}}\right) \times 100$

where $n$ is the number of observations per month and $f(\mathrm{VPD}$ roof $)$ and $f\left(\mathrm{VPD}_{\text {controll }}\right)$ are the average daily integrated sap flux densities of the targeted species in roof and control plots respectively, expressed as functions of VPD measured at the climate station.

\section{Soil water transport model}

\section{Soil bydraulic functions}

In order to assess differences in drainage and soil moisture storage among roof and control plots and to describe the processes of soil water transport, we applied the soil water transport model HYDRUS-1D (Šimůnek et al., 2008) which numerically solves the Richards equation for variably-saturated water flow. The soil water retention function implemented in HYDRUS-1D is given as (van Genuchten, 1980):

$S_{e}(b)=\frac{\theta(b)-\theta_{r}}{\theta_{s}-\theta_{r}}=\left[1+a(b)^{n}\right]^{-m}$

where $S_{e}\left(\mathrm{~cm}^{3} \mathrm{~cm}^{-3}\right)$ is the effective saturation, $\theta(h)\left(\mathrm{cm}^{3} \mathrm{~cm}^{-3}\right)$ is the volumetric soil water content at hydraulic head $b(\mathrm{~cm}), \theta_{s}$ and $\theta_{r}$ are saturated and residual water content $\left(\mathrm{cm}^{3} \mathrm{~cm}^{-3}\right), a$ $\left(\mathrm{cm}^{-1}\right)$ is the inverse of the air entry head and $m$ and $n$ are dimensionless curve shape parameters $\left(\mathrm{m}=1-\mathrm{n}^{-1}(-)\right)$. The hydraulic conductivity of the soil was described by Mualems' pore-size distribution model (Mualem, 1976):

$K\left(S_{e}\right)=K_{s a t} S_{e}^{\lambda}\left[1-\left(1-S_{e}^{1 / m}\right)^{m}\right]^{2}$

where $K\left(S_{e}\right)$ and $K_{\text {sat }}$ are the unsaturated and saturated hydraulic conductivities $\left(\mathrm{cm} \mathrm{day}^{-1}\right)$, and $\lambda(-)$ is the tortuosity parameter.

\section{Model parameterization}

Vertical soil heterogeneity was modeled using five soil layers in a profile $250 \mathrm{~cm}$ deep $(251$ nodes) such that two layers adjoined at the mean distance between two TDRs. Lacking enough replications of soil water content measurements at $250 \mathrm{~cm}$ depth we did not parameterize a sixth soil layer but extended the fifth layer towards $250 \mathrm{~cm}$. 
Boundary conditions were set to 'atmospheric with surface run off and 'free drainage'. Measured water contents provided the initial conditions. Time variable boundaries (input data) were net precipitation $\left(P_{n e t}, \mathrm{~mm}\right)$ and measured stand transpiration. Evaporation from the bare soil was considered negligible because the soil was well covered with litter and little radiation reached the ground. We established a linear regression from weekly measured canopy throughfall and gross precipitation $\left(P_{\text {gross }}\right.$, Moser, unpublished data) and applied it to daily rainfall data to derive throughfall on a daily basis. Daily canopy throughfall in roof plots accounts also for measured interception caused by the roofs. Stem flow amounted to $5 \%$ of gross precipitation (Schwendenmann, unpublished data) and was added to yield $P_{n e t}$. We did not apply the model to each plot separately due to the fact that $T$ and $P_{n e t}$ consisted of averages taken across all three roof plots and all three control plots. In addition, rock fragment content of the soil, soil texture and bulk density were averaged over all six plots as differences between plots were insignificant.

The root biomass of each species was measured in steps of $20 \mathrm{~cm}$ depth (Schwendenmann et al., 2010). Rooting patterns remained unchanged during the experiment (Schwendenmann et al., 2010). Fine root biomass declined exponentially with depth to zero at $240 \mathrm{~cm}$ with $67 \%$ of the total biomass being located in the top $40 \mathrm{~cm}$. We chose an S-shaped root water uptake stress response function (van Genuchten, 1987; van Genuchten and Gupta, 1993):

$$
\operatorname{ar}(b)=\frac{1}{\left[1+\left(\frac{h(z)}{h_{50}}\right)^{p}\right]}
$$

where $\operatorname{ar}(-)$ is the water stress response $(0<a r<1)$ with which potential root water uptake is multiplied, $h(z)(\mathrm{cm})$ is the soil water potential at location $z, h_{50}(\mathrm{~cm})$ is the soil water potential at which root water uptake rate is reduced by $50 \%$, and $p(-)$ is a fitting parameter. Like Sommer et al. (2003) we used actual transpiration as input and thus had to match potential and actual root water uptake. Hence we set $h_{50}$ and $p$ to arbitrarily high values of $-5000 \mathrm{~cm}$ and 6 to ensure that only very dry conditions could alter root water uptake. In case water uptake might still be reduced by low potentials, the root adaptability factor (Šimůnek et al., 2008) was set to zero so that hindered water uptake from one layer could be compensated for by increased uptake from another.

\section{Adjustment of soil bydraulic parameters}

Hydraulic parameters of the van Genuchten function estimated from laboratory pressure plate measurements (van Straaten, unpublished data) did not lead to model convergence in either roof or control plots. Such deviations between field and laboratory retention data are common. 
Therefore, in many studies soil hydraulic parameters are either iteratively adjusted by trial and error (e.g. Schlegel et al., 2004; Belk et al., 2007) or inversely estimated from measured soil water contents and/or potentials and evapotranspiration fluxes (e.g. Vrugt et al., 2001; Ritter et al., 2003; Sommer et al., 2003) for which we opted. HYDRUS-1D implements a MarquardtLevenberg type parameter estimation technique for the simultaneous fit of 15 hydraulic parameters (three per layer). The pedotransfer function of the ROSETTA software (Schaap et al., 2001) was used to derive initial estimations of the soil hydraulic parameters $\left(\theta_{s}, \theta_{r}, a, n\right.$ and $\left.K_{s a t}\right)$ from soil texture and bulk density for each layer. We set $\lambda$ to -1 as an improved prediction of unsaturated hydraulic conductivity was reported (Schaap and Leij, 2000) compared to the originally suggested $\lambda=0.5$ by Mualem (1975). In a sensitivity analysis based on comparison of the root mean square error (RMSE) of modeled and predicted water contents, we found $\theta_{s}, a$ and $n$ to have the largest impact on model fit. These were inversely optimized in this study, while $\theta_{r}$, and $K_{\text {sat }}$ were taken from the ROSETTA prediction. Because observed water contents entered the objective function during optimization, model evaluation is not strictly independent (Sommer et al., 2003). Thus we separated the measurement period into calibration and validation phases to evaluate the model performance.

\section{Data analyses}

Regression models and differences between them were considered significant if $\mathrm{p}<0.05$. In analogy to linear models we calculated $R^{2}$ adjusted also for nonlinear models. RMSE and NashSutcliffe model efficiency $E$ are given to judge the goodness of the model fit (Nash and Sutcliffe, 1970). E varies from - $\infty$ (negative values indicate that the average of a time series would be a better predictor than the model) to 1.0 (perfect fit). All data analyses were conducted with $\mathrm{R}$ version 2.8.1 (RDCT, 2008). 


\section{Results}

\section{Micrometeorological conditions and soil water content}

During the study period monthly gross precipitation ranged from $44 \mathrm{~mm} \mathrm{mon}^{-1}$ in January 2008 to $473 \mathrm{~mm} \mathrm{mon}^{-1}$ in April 2007. Annual gross precipitation was $2841 \mathrm{~mm} \mathrm{y}^{-1}$ (April 10, 2007 to April 09, 2008) which is 35\% higher than the 5 year average. A pronounced dry spell occurred in January/February 2008. Over the course of the study period mean daily maximum VPD was $2.3 \mathrm{kPa}$ and average daily air temperature was $24.5^{\circ} \mathrm{C}$ Average daily global radiation was $18.5 \mathrm{MJ} \mathrm{m}^{-2}$ day $^{-1}$ before the sensor malfunctioning started.

Soil water content in the control plots was close to saturation $\left(0.475 \mathrm{~cm}^{3} \mathrm{~cm}^{-3}\right.$ at $10 \mathrm{~cm}$ depth) throughout most of the experiment. Maximum levels of soil water content (mean $\pm \mathrm{SD}$ ) were $0.431 \pm 0.013 \mathrm{~cm}^{3} \mathrm{~cm}^{-3}$ at $10 \mathrm{~cm}$ depth and $0.307 \pm 0.016 \mathrm{~cm}^{3} \mathrm{~cm}^{-3}$ at $150 \mathrm{~cm}$ depth. The difference between highest and lowest soil water content ranged from $0.119 \pm 0.011 \mathrm{~cm}^{3} \mathrm{~cm}^{-3}$ at $10 \mathrm{~cm}$ depth to $0.051 \pm 0.001 \mathrm{~cm}^{3} \mathrm{~cm}^{-3}$ at $150 \mathrm{~cm}$ depth. The lowest soil water content was measured during the previously mentioned dry spell of 2008 .

Soil water content in the roof plots was similar to that of the control plots before roof installation. After roof installation soil water content in roof plots decreased in all layers except 250 $\mathrm{cm}$, which only began to decline after two and a half months of throughfall reduction. After a phase of relatively quick reduction in soil water content (March to June 2007), changes in soil water content subsided with time. The difference between highest and lowest water content ranged from $0.214 \pm 0.003 \mathrm{~cm}^{3} \mathrm{~cm}^{-3}$ at $10 \mathrm{~cm}$ to $0.121 \pm 0.027 \mathrm{~cm}^{3} \mathrm{~cm}^{-3}$ at $150 \mathrm{~cm}$ depth. Heavy precipitation events did lead to slight rewetting in the roof plots, especially in upper soil layers. The magnitude of rewetting declined with depth such that rewetting was barely visible between 75 and $250 \mathrm{~cm}$ depth. After roof removal, water content at all depths rose within three weeks but remained at a constant $10-15 \%$ lower than the maximum values observed before roof installation.

\section{Sap flux density and tree water use}

Daily integrated sap flux densities of cacao in the period before roof installation (February 2007 , mean \pm SD) were similar in both roof and control plots with $151.8 \pm 20.3$ and $151.5 \pm$ $25.3 \mathrm{~g} \mathrm{~cm}^{-2}$ day $^{-1}$, respectively. Sap flux density of Gliricidia trees within that time was slightly but insignificantly higher in roof plots $\left(154.9 \pm 43.6 \mathrm{~g} \mathrm{~cm}^{-2}\right.$ day $\left.^{-1}\right)$ as compared to control plots (143.8 $\left.\pm 16.6 \mathrm{~g} \mathrm{~cm}^{-2} \mathrm{day}^{-1}\right)$. The corresponding water use rates were 9.3 and $10.6 \mathrm{~kg} \mathrm{day}^{-1}$ for cacao and 14.5 and $13.3 \mathrm{~kg} \mathrm{day}^{-1}$ for Gliricidia in roof and control plots, respectively. The larger conductive 
sap wood area of Gliricidia led to higher $Q$ as compared to cacao despite similar sap flux densities in both species. Daily average $T$ was 1.3 and $1.5 \mathrm{~mm} \mathrm{day}^{-1}$ in roof and control plots, respectively. Cacao trees contributed approximately $70 \%$ of total stand transpiration in roof and control plots.

Monthly regression models of sap flux response to VPD showed no significant difference between roof and control plots before roof installation for either Gliricidia or cacao (Figure 1, A). From June (Gliricidia) and July 2007 (cacao) onward (4 and 5 months after roof closure) roof plots exhibited a significant decline $(\mathrm{p} \leq 0.05)$ in sap flux densities for both species. The sap flux decline was greatest for both species during February 2008, the month in which lowest soil water contents were measured (Figure 1 (B)). Some differences were observed between the two species. For cacao, sap flux densities at low VPD in roof plots were comparable to those of the control, however Gliricidia exhibited sap flux densities below those of the control at low VPD. This pattern was observed over the whole duration of the throughfall reduction period. Gliricidia sap flux in roof plots fully recovered one month after the experiment (Figure $1 \mathrm{C}$ ), while cacao sap flux had already recovered one month before roof removal (March 2008) during heavy rainwater intrusion partially rewetting the topsoil in roof plots.

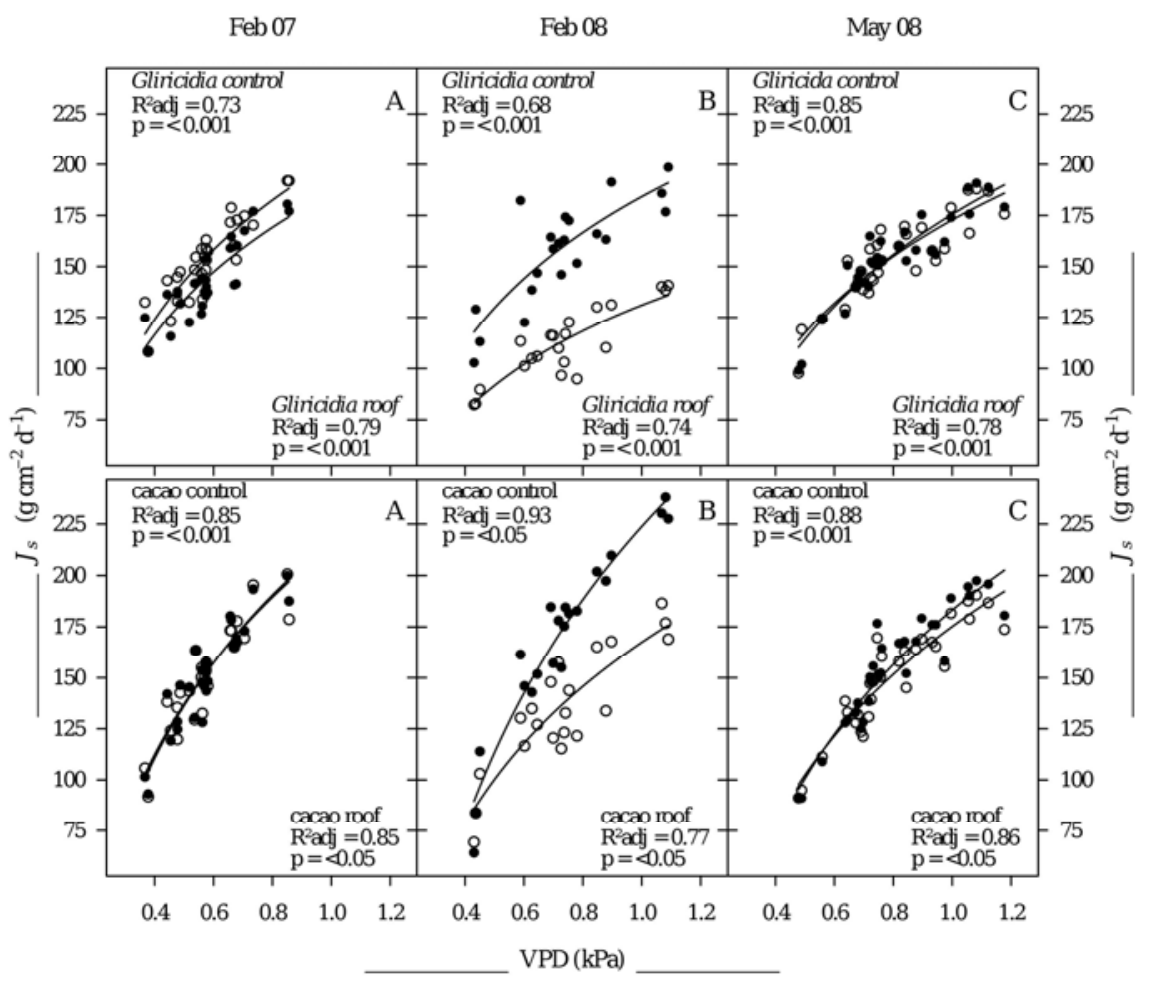

Figure 1: Daily integrated average sap flux density $\left(J_{s}, \mathrm{n}=9\right)$ in roof (open circles) and control plots (dots) as functions of daily average VPD for Gliricidia (upper graphs) and cacao (lower graphs). The relationships are shown for February 2007 (pre-treatment), February 2008 (treatment) and May 2008 (post treatment). 
Sap flux density in control plots was not influenced by changes in soil water content, so we expressed the sap flux reduction coefficient as a function of soil water content in roof plots at 10 cm depth (Figure 2). Sap flux reduction increased linearly with decreasing soil water content, reaching a maximum of $29.0 \%$ reduction in Gliricidia and $20.1 \%$ in cacao. Lowest reduction coefficients were found within the first three months of the experiment $(-7.2 \%$ and $-4.8 \%$ for Gliricidia and cacao) indicating slightly higher sap flux densities in roof plots at that time.

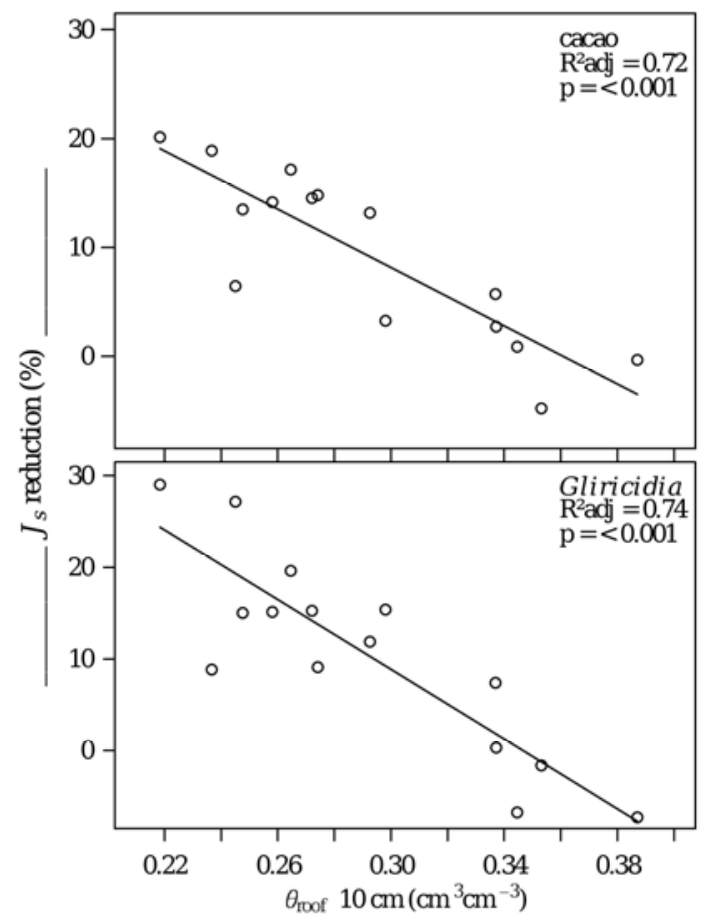

Figure 2: Monthly reduction coefficient of integrated daily sap flux density $\left(J_{s}, \mathrm{n}=9\right)$ in cacao and Gliricidia as functions of average volumetric water content in roof plots $\left(\theta_{\text {roof }}, \mathrm{n}=9\right)$ at $10 \mathrm{~cm}$ depth.

\section{Soil water model and stand water budget}

Inversely estimated hydraulic functions differed between roof and control plots in $a$ and $n$ while $\theta_{s}$ remained similar to the primary ROSETTA estimates (Table 2). Driven by higher values of $a$ in the upper four soil layers of roof plots, hydraulic heads were lower in roof plots than in control plots at any given water content. Larger $n$ values in the control led to smaller slopes in the retention curves for control plots (upper 4 layers) such that changes in head were smaller over a wide range of water contents than in roof plots. In contrast, in the layer between 113 $250 \mathrm{~cm}$ control plots exhibited much lower hydraulic heads at given water contents (higher $n$ and lower $a$ compared to the roof plots). Simulated root zone pressure heads at lowest water contents were approximately $-2100 \mathrm{~cm}$ in roof plots and $-520 \mathrm{~cm}$ in control plots. Stand transpira- 
tion entering the model as input variable was only marginally reduced $(<0.1 \mathrm{~mm})$ in both, roof and control by the root water uptake stress response function.

Table 2: Effective soil hydraulic parameters (saturated $\left(\theta_{s}\right)$ and residual water content $\left(\theta_{r}\right)$, inverse of the air entry head $(a)$, curve shape parameter $(n)$ and saturated hydraulic conductivity $\left(K_{\text {sat }}\right)$ as determined by ROSETTA or inversely predicted by HYDRUS $1 \mathrm{D}$ for average roof and control plots.

\begin{tabular}{lcccccc}
\hline Treatment & $\begin{array}{c}\text { Soil layer } \\
(\mathrm{cm})\end{array}$ & $\begin{array}{c}\theta_{s}{ }^{a} \\
\left(\mathrm{~cm}^{3} \mathrm{~cm}^{-3}\right)\end{array}$ & $\begin{array}{c}\theta_{r} \mathrm{~b} \\
\left(\mathrm{~cm}^{3} \mathrm{~cm}^{-3}\right)\end{array}$ & $\begin{array}{c}a^{a} \\
\left(\mathrm{~cm}^{-1}\right)\end{array}$ & $\begin{array}{c}n^{a} \\
(-)\end{array}$ & $\begin{array}{c}K_{\text {sat }} \mathrm{b} \\
\left(\mathrm{cm} \mathrm{day}^{-1}\right)\end{array}$ \\
\hline \multirow{4}{*}{ Roof } & $0-15$ & 0.383 & 0.055 & 0.001426 & 1.60 & 49.15 \\
& $15-30$ & 0.399 & 0.056 & 0.002164 & 1.47 & 43.84 \\
& $30-58$ & 0.427 & 0.062 & 0.004525 & 1.30 & 35.63 \\
& $58-113$ & 0.412 & 0.061 & 0.009331 & 1.27 & 34.83 \\
& $113-250$ & 0.307 & 0.041 & 0.004273 & 1.39 & 41.39 \\
\hline \multirow{4}{*}{ Control } & $0-15$ & 0.416 & 0.055 & 0.001417 & 3.23 & 49.15 \\
& $15-30$ & 0.424 & 0.056 & 0.001234 & 2.82 & 43.84 \\
& $30-58$ & 0.425 & 0.062 & 0.001003 & 2.22 & 35.63 \\
& $58-113$ & 0.371 & 0.061 & 0.001307 & 1.80 & 34.83 \\
\hline
\end{tabular}

$\overline{\text { a Inversely estimated, b ROSETTA estimate from soil texture and bulk }} \frac{1.11}{\text { density }}$

Overall model efficiency and RMSE were satisfying (Table 3). In general, deviations between measured and modeled water contents were small and declined with depth as indicated by decreasing RMSE. While calibration and validation phases in roof plots showed similar RMSE and $E$ at each depth, fits in control plots were much better in the calibration phase than in the validation phase. In the control, peak water contents were slightly underestimated between depths of 10 to $75 \mathrm{~cm}$ and water contents were overestimated at $150 \mathrm{~cm}$ (Figure 3).

Table 3: Nash-Sutcliffe model efficiency $(E)$ and randomized mean square error (RMSE) for the comparison between simulated and measured soil water contents of the soil layers of the calibration (cal.), validation (val.) and full study period (full) for average roof and control plots.

\begin{tabular}{|c|c|c|c|c|c|c|c|}
\hline Treatment & $\begin{array}{c}\text { Soil layer } \\
(\mathrm{cm})\end{array}$ & $\begin{array}{c}E \text { (cal.) } \\
(-) \\
\end{array}$ & $\begin{array}{c}E \text { (val.) } \\
(-)\end{array}$ & $\begin{array}{c}E \text { (full) } \\
(-) \\
\end{array}$ & $\begin{array}{c}\text { RMSE } \\
\text { (cal.) } \\
\left(\mathrm{cm}^{3} \mathrm{~cm}^{-3}\right)\end{array}$ & $\begin{array}{c}\text { RMSE } \\
\text { (val.) } \\
\left(\mathrm{cm}^{3} \mathrm{~cm}^{-3}\right) \\
\end{array}$ & $\begin{array}{c}\text { RMSE } \\
\text { (full) } \\
\left(\mathrm{cm}^{3} \mathrm{~cm}^{-3}\right)\end{array}$ \\
\hline \multirow{5}{*}{ Roof } & $0-15$ & 0.83 & 0.81 & 0.86 & 0.021 & 0.020 & 0.020 \\
\hline & $15-30$ & 0.90 & 0.90 & 0.92 & 0.014 & 0.013 & 0.014 \\
\hline & $30-58$ & 0.82 & 0.88 & 0.87 & 0.020 & 0.013 & 0.017 \\
\hline & 58-113 & 0.91 & 0.94 & 0.94 & 0.009 & 0.008 & 0.008 \\
\hline & $113-250$ & 0.92 & 0.88 & 0.93 & 0.009 & 0.009 & 0.009 \\
\hline \multirow{5}{*}{ Control } & $0-15$ & 0.87 & 0.54 & 0.77 & 0.010 & 0.013 & 0.011 \\
\hline & $15-30$ & 0.92 & 0.51 & 0.77 & 0.006 & 0.010 & 0.008 \\
\hline & $30-58$ & 0.89 & 0.42 & 0.68 & 0.004 & 0.008 & 0.006 \\
\hline & $58-113$ & 0.89 & 0.61 & 0.79 & 0.005 & 0.007 & 0.006 \\
\hline & $113-250$ & 0.77 & 0.46 & 0.62 & 0.005 & 0.006 & 0.005 \\
\hline
\end{tabular}




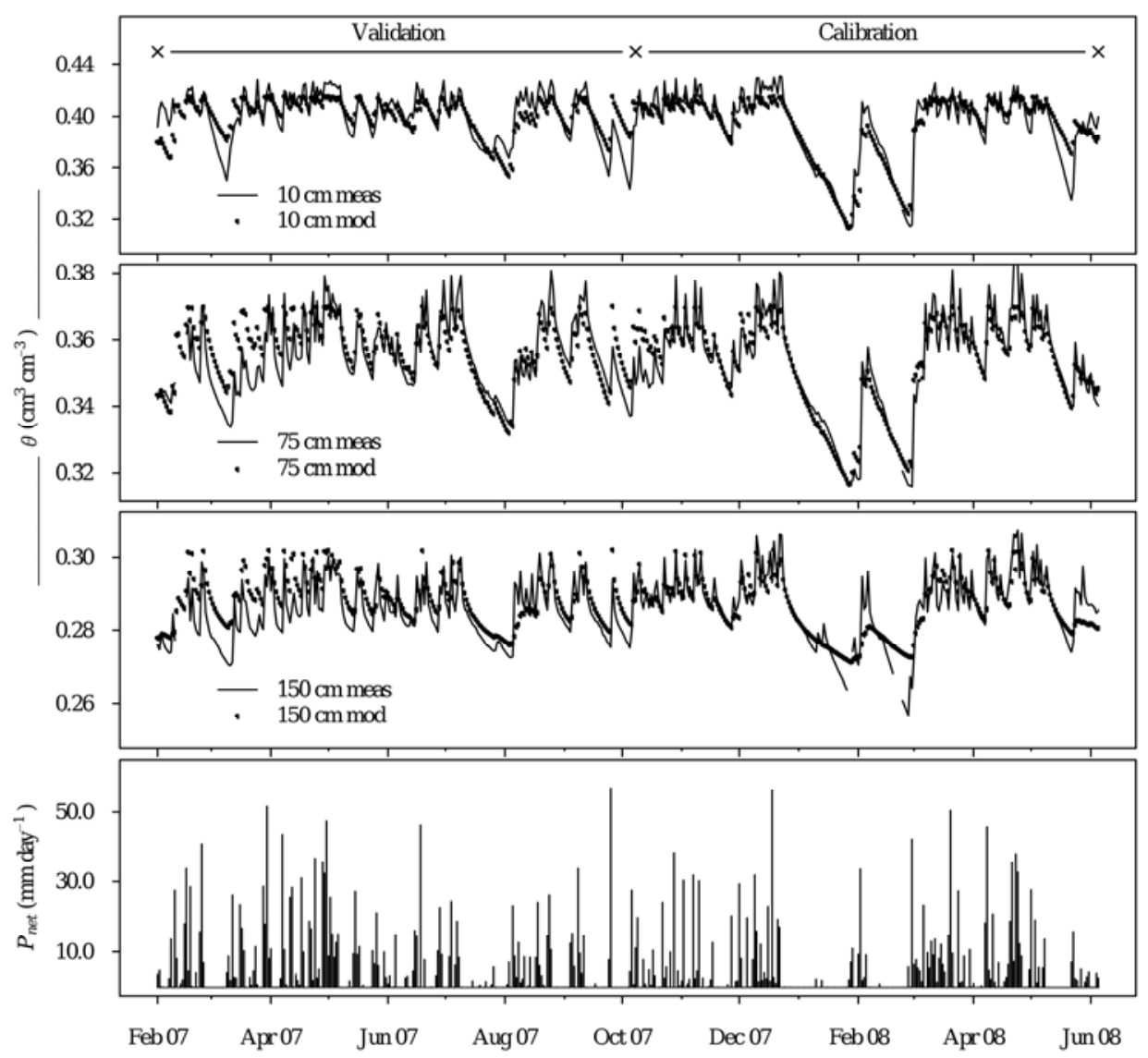

Figure 3: Simulated (dots) and measured (lines) soil water content $(\theta, \mathrm{n}=3)$ at 10,70 and $150 \mathrm{~cm}$ depth and net precipitation $\left(P_{n e t}\right)$ in control plots. The lines at top of the uppermost graph indicate calibration and validation periods used.

The water budget for 12 months (April 10, 2007 to April 09, 2008) indicated that $80 \%$ of $P_{n e t}$ went to transpiration in roof plots and $26 \%$ went to transpiration in control plots (Table 4). In April, August and December 2007 and in March 2008 more water entered the soil than was withdrawn by roots. Soil moisture storage (SMS) in the control underwent only minor variations over the course of the year. In contrast, roof plots showed greatly reduced SMS due to drainage in the early stages of the experiment and due to transpiration in more advanced stages.

Table 4: Gross and net precipitation $\left(P_{\text {gross }}, P_{n e t}\right)$, Drainage at $250 \mathrm{~cm}$ depth $(D)$ and change in soil moisture storage between 0 and $250 \mathrm{~cm}$ depth $(\triangle S M S)$ from April 10, 2007 to April 9, 2008 for average roof and control plots during the period of throughfall reduction..

\begin{tabular}{lccccc}
\hline Treatment & $\begin{array}{c}P_{\text {gross }} \\
\left(\mathrm{mm} \mathrm{y}^{-1}\right)\end{array}$ & $\begin{array}{c}P_{\text {net }} \\
\left(\mathrm{mm} \mathrm{y}^{-1}\right)\end{array}$ & $\begin{array}{c}T \\
\left(\mathrm{~mm} \mathrm{y}^{-1}\right)\end{array}$ & $\begin{array}{c}D \\
\left(\mathrm{~mm} \mathrm{y}^{-1}\right)\end{array}$ & $\begin{array}{c}\Delta S M S \\
\left(\mathrm{~mm} \mathrm{y}^{-1}\right)\end{array}$ \\
\hline Roof & 2841 & 611 & 491 & 299 & -179 \\
Control & 2117 & 560 & 1554 & 4 \\
\hline
\end{tabular}

SMS in roof plots did not return to its initial levels after roof removal, as indicated by lower maximum water contents after roof removal compared to beginning of the measurements (see 
Figure 4). Daily drainage rates in the control plots averaged $\sim 4 \mathrm{~mm} \mathrm{day}^{-1}$ over the 12 month period. In roof plots drainage averaged $\sim 6 \mathrm{~mm} \mathrm{day}^{-1}$ prior to roof installation.

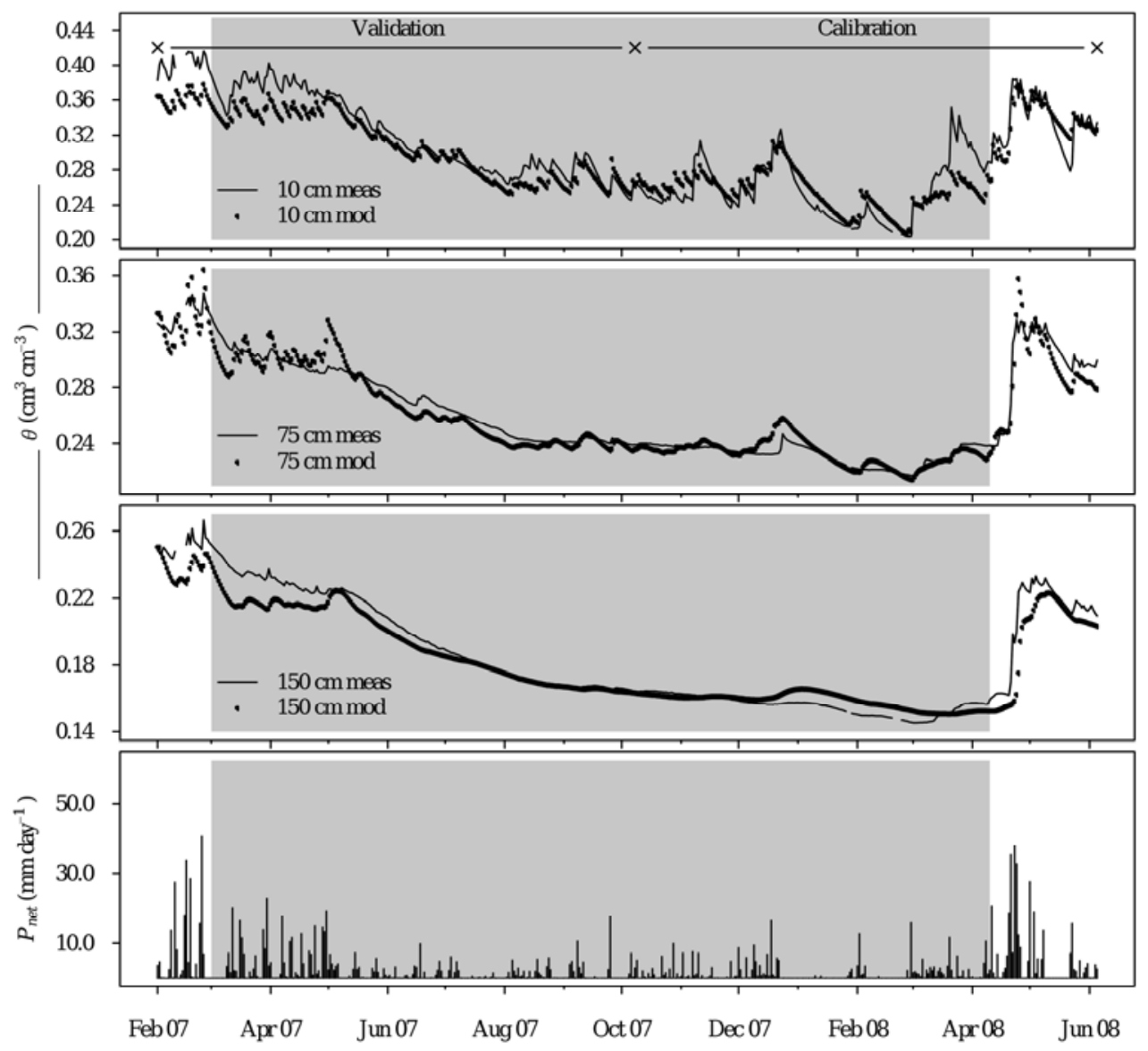

Figure 4: Simulated (dotted lines) and measured (solid lines) average soil water content $(\theta, \mathrm{n}=3)$ at 10 , 70 and $150 \mathrm{~cm}$ depth and net precipitation $\left(P_{n e t}\right)$ in roof plots. The grey area indicates the time of throughfall reduction. Lines at the top of the uppermost graph indicate the calibration and validation periods used.

Following roof installation drainage declined, reaching an inflection point in mid June 2007. At this point, drainage rates were similar to daily transpiration rates $\left(\sim 1.5 \mathrm{~mm} \mathrm{~d}^{-1}\right.$, Figure 5). From July 2007 onward the decrease in drainage rates leveled off, approaching values less than $0.1 \mathrm{~mm} \mathrm{day}^{-1}$ during the last month of the throughfall reduction experiment. Despite the strong reduction in drainage, a total of $97 \mathrm{~mm}$ of water drained from the soil profile following July 2007 , an amount equal to approximately $25 \%$ of cumulative transpiration during that time. After the roof was removed, it took one month for drainage rates in the roof plots to return to levels similar to those of the control plots. 


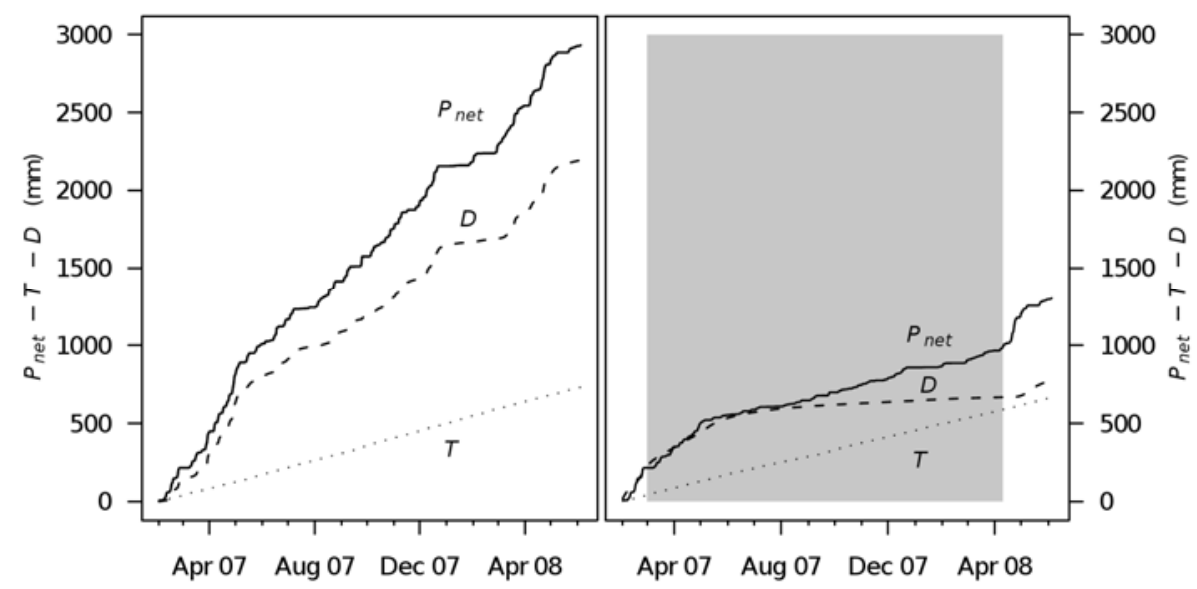

Figure 5: Cumulated net precipitation $\left(P_{n e t}\right.$, solid line), drainage $(D$, dashed line) and stand transpiration $(T$, dotted line) in control (left) and roof plots (right). The grey area depicts the time of throughfall reduction.

\section{Discussion}

Sap flux density response to decreasing soil water content

Before roof setup, daily integrated sap flux densities did not differ between roof and control plots. Tree sap flux density and water use in this stand under ambient conditions were found to be in line with values reported for trees of similar age and size in the tropics (Köhler et al., 2009). Sap flux in both Gliricidia and cacao declined with declining soil water content in roof plots. Despite the often higher evaporative demand associated with dry conditions, a number of studies have found lower sap flux densities under natural dry conditions than under natural wet conditions (e.g. Pataki et al., 2000; Hölscher et al., 2005; Kume et al., 2007). In contrast, O’Grady et al. (1999) found higher sap flux in a eucalyptus forest in Northern Australia during drought due to higher evaporative demand and deep soil water exploration. However, in our experiment fine roots only reached down to about $240 \mathrm{~cm}$ and evaporative demand was the same for all plots (Schwendenmann et al., 2010).

In our experiment cacao trees were found less sensitive to reduced soil water content. In contrast to Gliricidia, cacao sap flux densities during the period of roof closure were only reduced at high levels of VPD (Figure 1 B) and the sap flux reduction was less pronounced under dry conditions (Figure 2). The different responses of cacao and Gliricidia to reduced soil water content might have several causes:

1) Based on the root distribution of both species, soil water partitioning may have occurred such that cacao drew water mainly from the topsoil while Gliricidia relied on water reserves from deeper soil layers. More than $80 \%$ of the cacao fine root biomass was located in the top $40 \mathrm{~cm}$ of 
soil (Schwendenmann et al., 2010), while total Gliricidia fine root biomass was more evenly distributed in the soil profile (Moser et al., in press) with a pronounced peak between 0.5 and $1.5 \mathrm{~m}$. Thus, competition for water in the upper soil layers may have been avoided or favored cacao. This finding is supported by a slightly higher correlation in Gliricidia and a much weaker correlation in cacao between the sap flux reduction coefficient and soil water content at $75 \mathrm{~cm}$ depth in roof plots (Data not shown). This confirms the evidence of soil water partitioning derived from stable isotope analysis conducted before roof installation in which cacao appeared to use water mainly from the upper $30 \mathrm{~cm}$ while Gliricidia obtained water from depths below $30 \mathrm{~cm}$ (Schwendenmann et al., 2010). However, no stable isotope data are available yet for the time during roof closure. Thus it remains unknown if these patterns changed with time.

Soil water partitioning can also help explain the recovery of cacao sap flux densities before roof removal, as cacao would have made better use of water present in upper soil layers following rain events. In an Amazonian rainforest, Fisher et al. (2007) reported an immediate recovery of tree sap flux in their throughfall reduction plot within two days after a large rain event triggered rewetting. This evidence contrasts with the delayed response of Gliricidia trees to rewetting in our experiment but is comparable to the quick response of cacao to the rain event before roof opening. Vertical water uptake partitioning might have played a minor role in the Amazon, but other plant and environmental parameters such as tree size, amount of precipitation and antecedent soil water content could also be responsible for differences in sap flux response to rewetting (Zeppel et al., 2008).

Surprisingly, the shallow rooted cacao is less sensitive to reduced throughfall than the deeper rooted Gliricidia. But it has to be considered that the throughfall entering gaps in the roof partially rewetted the top soil but did not penetrate into the subsoil where it could have been beneficial for Gliricidia. Furthermore, the rock fragment content of the soil was highest at depths where also most Gliricidia roots where located which potentially restricted root water uptake further. Gliricidia is also known to possess a relatively incompetitive root system (Schroth and Lehmann, 1995; Schroth and Zech, 1995). Therefore, not only root distribution but also root functioning (Ong et al, 1999), and a variety of other factors determine whether trees compete for belowground resources or use them complementarily (Schroth, 1999; Jose et al., 2006).

2) Cacao leaves could be somewhat uncoupled from the bulk atmosphere due to shading and low wind speed inside of the stand while crowns of Gliricidia experience greater exposure. Such uncoupling could lead to a decrease in leaf boundary layer conductance and thus to a lower evaporative demand on the leaf level in cacao leading to a higher water stress resilience. Evidence 
for uncoupling has been found for coffee under shade trees (van Kanten and Vaast, 2006) and gap colonizing tree species in tropical forests (Meinzer et al., 1995). Uncoupling can lead to a limited control of transpiration by stomata. In contrast, effective stomatal control of transpiration by cacao leaves under water deficit was reported for cacao Joly and Hahn, 1989, Balasimha et al., 1991), a finding which might be attributed to the atmospheric conditions and shading regimes particular to their experiments.

It can also be assumed that VPD at the height where cacao crowns expand was lower than VPD measured in the open where most Gliricidia leaves are found. Thus, regression models of sap flux response to VPD can be similar for both species but might be shifted toward lower values of VPD for cacao.

3) In contrast to Gliricidia, cacao in this stand became acclimated to drier conditions through osmotic adjustment of root water potential. For further discussion see Moser et al. (in press).

4) If root water uptake cannot balance transpiration rates (e.g. rapid onset of morning transpiration, high resistance along the soil - leaf pathway), transpiration can be supported by the short term depletion of stem water storage during the day (Goldstein et al., 1998), which will be refilled as transpiration rates drop again. The data could therefore also suggest that cacao has more readily available stem water storage capacity.

Despite the reduction in sap flux densities among trees in the roof plots, none of the species showed significant reduction of biomass production during our experiment (Schwendenmann et al., 2010), indicating increased water use efficiency. Cacao yield in roof plots, however, was found to be $50 \%$ lower in the main harvest period following the opening of the roof (April June 2008); an indication that reduced soil water availability during pod development $(5-6$ months) had an important effect on generative growth. Nevertheless, cacao bean yield contributed only about $6 \%$ to total biomass production (Schwendenmann et al., 2010). The extent to which the reproductive state of Gliricidia trees was affected by drought could not be assessed.

\section{Soil water model and stand water budget}

RMSE and model efficiencies $(E)$ indicated appropriate model performance with the exception of very low efficiencies found during the validation phase of the control (Table 3). $E$ is known to underestimate model performance in time series showing little variation (Krause et al., 2005). This was the case for the validation phase of the control plots, further reducing the already low expected efficiency. Nonetheless, RMSE showed that deviations were small. RMSE were generally highest in upper soil layers where water dynamics were greatest; however, devia- 
tions here had little influence on the total water balance as top soil layers were narrow and thus did not contribute significantly to total soil water storage. Ritter et al. (2003) found that small deviations in RMSE between measured and modeled water contents had large influences on soil water drainage when comparing estimated hydraulic parameters from field samples, trial and error optimization and inverse adjustment. Because inverse methods minimize RMSE, we conclude that our approach was appropriate to obtain accurate data on drainage and soil water movement.

Soil hydraulic parameters differed between roof and control plots (Table 2). This could be attributed to a number of causes, including: some degree of ill posedness (equifinality) of the problem (Jhorar et al., 2002; Ritter et al., 2003), the small range of water contents measured in control plots, or the effects of hysteresis in roof plots (see Durner et al., 2002) on a short discussion of hysteresis and inverse modeling). Evidence of hysteresis can also be found in the larger deviation of the model's fit from the measured data at the beginning of the validation phase, an occurrence which can be attributed to lower measured soil water contents during calibration than during validation (Figure 4). A calibration using roof data and a validation with control data did also not lead to model convergence from which we conclude that soil hydraulic parameters are only representative for the respective treatment in or from which they were derived.

A certain limitation of the study was that soil water potential could not be monitored alongside with soil water content at a series of depths. An indication to quantify the water status of the soil was also seen in the laboratory derived soil water retention functions (van Straaten, unpublished data). According to these functions, the soil water potential in roof plots at 10 and $75 \mathrm{~cm}$ depth was close to the permanent wilting point $(-15000 \mathrm{~cm})$ during the dry spell in 2008 . However, the soil water transport model revealed that the laboratory derived retention functions were not suitable to describe the water movement in the soil. In addition, the minimum root zone water potential modeled for roof plots employing soil water retention functions based on theoretical assumptions about soil texture was higher at that time. Unfortunately measured root water potentials (minimum of $-9700 \mathrm{~cm}$ and $-5100 \mathrm{~cm}$ for cacao and Gliricidia in September 2007; Moser et al. (in press)) could also not be used to verify the theoretical or the laboratory derived retention functions, because these potentials where not assessed at predawn. Therefore, no tree specific root water uptake parameters can be ascertained by this study and the severity of the drought cannot be finally judged based on the soil water status.

Rainfall interception by the canopy amounted to $25 \%$ of $P_{\text {gross }}$ which is $5 \%$ higher than for cacao agroforests under remaining rainforest trees in the study region (Dietz et al., 2006), but 
considerably lower than the $35 \%$ (without ground litter interception) given for cacao under Erythrina fusca (de Miranda, 1994). Nonetheless, stem flow (5\% of $\left.P_{\text {gross }}\right)$ was higher than the $1 \%$ and $2 \%$ of $P_{\text {gross }}$ given by Dietz et al. (2006) and de Miranda (1994) respectively.

Stand transpiration in control plots $\left(1.5 \mathrm{~mm} \mathrm{day}^{-1}\right)$ was less than half of that estimated in both Amazonian rainforest experiments (Belk et al., 2007; Fisher et al., 2007). There is also evidence from energy flux measurements in Central Sulawesi, Indonesia suggesting that rainforest conversion to cacao agroforests leads to a reduction of (evapo)transpiration (Ibrom et al., 2007). Low transpiration rates are beneficial during drought because stored water is sufficient over longer periods of time when depleted at a lower rate. $T$ in roof plots $\left(1.3 \mathrm{~mm}^{\mathrm{day}}{ }^{-1}\right)$ was on average $12 \%$ lower than the control with a maximum difference of $35 \%$ during the dry spell. Because cacao trees showed less sap flux reduction than Gliricidia but contributed $\sim 70 \%$ to $T$, the overall decline in $T$ was moderate. The throughfall reduction experiment in the Eastern Amazonian rain forest revealed a much larger yearly average (41\%) and maximal reduction (80\%) of $T$, although the percentage of $P_{n e t}$ used for transpiration was only about 10\% higher than the percentage used in our experiment (Fisher et al., 2007). Such strong reactions are caused by a natural dry season of five months in the Central Amazon, during which sap flux in the control was already 29\% lower than during the wet season. Transpiration was not measured in the East-Central Amazonian experiment (Nepstad et al., 2002), but the results of a soil water modeling study at this site suggested that there was only a minor reduction in transpiration (5\% average and $13 \%$ maximum reduction) during the first two experimental years (Belk et al., 2007). This small reduction of $T$ can be explained by the removal of the roof during the dry seasons, reducing the impact of the throughfall reduction. In addition, deep roots played a large role in water uptake in the EastCentral Amazonian experiment, while a stony laterite layer was supposed to prevented root growth below 3-4 $\mathrm{m}$ in the Eastern Amazon (Fisher et al., 2007), and rooting depth was generally lower in our experiment.

Because $P_{n e t}$ exceeded T while SMS was decreasing, drainage in roof plots was a major driving force behind changes in soil water content during the 12 months in which the water balance was established (Table 4). Drainage was high for four consecutive months after roof closure and began to level off in mid June 2007 (Figure 5), when root water uptake became the governing force behind soil water movement. This point coincided with a significant reduction of Gliricidia sap flux densities in roof plots while cacao responded one month later. Both species maintained high transpiration only where high drainage rates indicated that surplus water was available. Total drainage after the inflection point amounted to $25 \%$ of cumulative transpiration from that time until roof opening, highlighting again the important impact of drainage on soil moisture storage. 
Because root water uptake decreased with depth and precipitation did not reach lower soil layers, changes in $S M S$ were governed by drainage in deeper soil layers while precipitation and root water uptake were the main influencing factors for the topsoil.

\section{Conclusion}

Agroforestry systems have to cope with changing climate and droughts are predicted to become more frequent and more severe. In order to reduce competition for water the removal of otherwise ecologically beneficial shade trees may therefore be considered. In contrast to this assumption, our study suggests that competition between Gliricidia shade trees and cacao for water resources during long periods with only little precipitation was low or would favor cacao. Water uptake partitioning may have allowed cacao to benefit from small amounts of throughfall, while the species also showed acclimation to water stress by osmotic adjustment in the roots and benefited from shading provided by taller Gliricidia trees. The low stand transpiration rates further contributed to the relatively high tolerance of this agroforest to reduce throughfall as competition for available water resources is reduced. However, throughout the throughfall reduction experiment, also drainage was a strong driving force behind declining soil moisture storage which indicates that $P_{n e t}$ exceeded $T$ during some months of the experiment.

\section{Acknowledgements}

This study was conducted in the framework of the joint Indonesian-German research project 'Stability of Tropical Rainforest Margins, Indonesia (STORMA)' funded by the German Research Foundation (SFB 552, sub-project B4). We would also like to thank Diego Dierick, Hendrayanto and Uswah Hasanah for their support, two anonymous reviewers for valuable comments on the manuscript, and Sara Hunt for English syntax and grammar editing.

\section{Acknowledgements}

This study was conducted in the framework of the joint Indonesian-German research project 'Stability of Tropical Rainforest Margins, Indonesia (STORMA)' funded by the German Research Foundation (SFB 552, sub-project B4). We would also like to thank Diego Dierick and two anonymous reviewers for valuable comments on the manuscript, and Sara Hunt for English syntax and grammar editing. 


\section{References}

Balasimha et al., 1991 D. Balasimha, E.V. Daniel and P.G. Bhat, Influence of environmental factors on photosynthesis on cocoa trees, Agric. Forest Meteorol. 55 (1991), pp. 15-21.

Belk et al., 2007 E.L. Belk, D. Markewitz, T.C. Rasmussen, E.J.M. Carvalho, D.C. Nepstad and E.A. Davidson, Modeling the effects of throughfall reduction on soil water content in a Brazilian Oxisol under a moist tropical forest, Water Resour. Res. 43 (2007), p. W08432.

Bredemeier et al., 1998 M. Bredemeier, K. Blanck, A. Dohrenbusch, N. Lamersdorf, A.C. Meyer, D. Murach, A. Parth and Y.J. $\mathrm{Xu}$, The Solling roof project-site characteristics, experiments, and results, Forest Ecol. Manag. 101 (1998), pp. 281-293.

Bruijnzeel, 1996 L.A. Bruijnzeel, Predicting the hydrological impacts of land cover transformation in the humid tropics: the need for integrated research. In: J.H.C. Gash, C.A. Nobre, J.M. Roberts and R.L. Victoria, Editors, Amazonian Deforestation and Climate, John Wiley \& Sons, New York (1996), pp. 15-55.

De Miranda, 1994 R.A.C. De Miranda, Partitioning of rainfall in a cocoa (Theobroma cacao L.) plantation, Hydrol. Processes 8 (1994), pp. 351-358.

Dierick et al., 2010 D. Dierick, N. Kunert, M. Köhler, L. Schwendenmann and D. Hölscher, Comparison of tree water use characteristics in reforestation and agroforestry stands across the tropics. In: T. Tscharntke, C. Leuschner, E. Veldkamp, H. Faust, E. Guhardja and A. Bidin, Editors, Tropical Rainforests and Agroforests under Global Change, Springer, Berlin (2010).

Dietz et al., 2006 J. Dietz, D. Hölscher, C. Leuschner and Hendrayanto, Rainfall partitioning in relation to forest structure in differently managed montane forest stands in Central Sulawesi Indonesia, For. Ecol. Manage. 237 (2006), pp. 170-178.

Durner et al., 1999 W. Durner, B. Schultze and T. Zurmühl, State-of-the-art in inverse modeling of inflow/outflow experiments. In: M.Th. van Genuchten, F.J. Leij and L. Wu, Editors, Proc. Int. Workshop on Characterization and Measurement of the Hydraulic Properties of Unsaturated Porous Media, October 22-24, 1997, University of California, Riverside, CA (1999), pp. 661681.

Fay et al., 2000 P.A. Fay, J.D. Carlisle, A.K. Knapp, J.M. Blair and S.L. Collins, Altering rainfall timing and quantity in a mesic grassland ecosystem: design and performance of rainfall manipulations shelters, Ecosystems 3 (2000), pp. 308-319.

Fiès et al., 2002 J.C. Fiès, N. De Louvigny and A. Chanzy, The role of stones in soil water retention, Eur. J. Soil Sci. 53 (2002), pp. 95-104.

Fisher et al., 2007 R.A. Fisher, M. Williams, A.L. da Costa, Y. Malhi, R.F. da Costa, S. Almeida and P. Meir, The response of an eastern Amazonian rain forest to drought stress: results and modelling analyses from a through-fall exclusion experiment, Glob. Change Biol. 13 (2007), pp. 2361-2378.

Gebre et al., 1998 G.M. Gebre, T.J. Tschaplinski and T.L. Shirshac, Water relations of several hardwood species in response to throughfall manipulation in an upland oak forest during a wet year, Tree Physiol. 18 (1998), pp. 299-305.

Goldstein et al., 1998 G. Goldstein, J.L. Andrade, F.C. Meinzer, N.M. Holbrook, J. Cavelier, P. Jackson and A. Celis, Stem water storage and diurnal patterns of water use in tropical forest canopy trees, Plant Cell Environ. 21 (1998), pp. 397-406.

Granier, 1987 A. Granier, Evaluation of transpiration in a Douglas-fir stand by means of sap flow measurements, Tree Physiol. 3 (1987), pp. 309-320.

Hanson, 2000 P.J. Hanson, Large -scale water manipulations. In: O.E. Sala, R.B. Jackson, H.A. Mooney and R.H. Howarth, Editors, Methods in Ecosystem Science, Springer, Berlin, Heidelberg, New York (2000), pp. 341-352.

Hanson et al., 1998 Hanson, P.J., Todd, D.E., Huston, M.A., Joslin, J.D., Croker, J.L., Augé, R.M., 1998. Description and field performance of the Walker branch throughfall displacement experiment: 1993-1996. ORNL/TM-13586, Oak Ridge National Laboratory, Oak Ridge, TN, 46 p.

Hölscher et al., 2005 D. Hölscher, O. Koch, S. Korn and C. Leuschner, Sap flux of five co-occurring tree species in a temperate broad-leaved forest during seasonal soil drought, Trees 19 (2005), pp. 628-637. 
Ibrom et al., 2007 A. Ibrom, A. Oltchev, T. June, T. Ross, H. Kreilein, U. Falk, J. Merklein, A. Twele, G. Rakkibu, S. Grote, A. Rauf and G. Gravenhorst, Effects of land-use change on matter and energy exchange between ecosystems in the rain forest margin and the atmosphere. In: T. Tscharntke, Ch. Leuschner, M. Zeller, E. Guhardja and A. Bidin, Editors, The Stability of Tropical Rainforest Margins: Linking Ecological, Economic and Social Constraints, Springer, Berlin (2007), pp. 463-492.

ICCO, 2009 ICCO, 2009. Quarterly Bulletin of Cocoa Statistics. Vol. XXXV, No. 2.

Jhorar et al., 2002 R.K. Jhorar, W.G.M. Bastiaanssen, R.A. Feddes and J.C. van Dam, Inversely estimating soil hydraulic functions using evapotranspiration fluxes, J. Hydrol. 258 (2002), pp. 198-213.

Joly and Hahn, 1989 R.J. Joly and D.T. Hahn, Net CO2 assimilation of cacao seedlings during periods of plant water deficit, Photosyn. Res. 21 (1989), pp. 151-159.

Jose et al., 2006 S. Jose, R. Williams and D. Zamora, Belowground ecological interactions in mixed species plantations, For. Ecol. Manag. 233 (2006), pp. 231-239.

Köhler et al., 2009 M. Köhler, D. Dierick, L. Schwendenmann and D. Hölscher, Water use characteristics of cacao and Gliricidia trees in an agroforest in Central Sulawesi Indonesia, Ecohydrology 2 (2009), pp. 520-529.

Krause et al., 2005 P. Krause, D.P. Boyle and F. Bäse, Comparison of different efficiency criteria for hydrological model assessment, Adv. Geosci. 5 (2005), pp. 89-97. Full Text via CrossRef | View Record in Scopus | Cited By in Scopus (58)

Kume et al., 2007 T. Kume, H. Takizawac, N. Yoshifujib, K. Tanakad, C. Tantasirine, N. Tanakab and M. Suzukib, Impact of soil drought on sap flow and water status of evergreen trees in a tropical monsoon forest in northern Thailand, For. Ecol. Manag. 238 (2007), pp. 220-230.

Leakey, 1999 R.R.B. Leakey, Agroforestry for biodiversity in farming systems. In: W.W. Collins and C.O. Qualset, Editors, Biodiversity in Agroecosystems, CRC Press, Boca Raton, USA (1999), pp. 127-145.

Meinzer, 2003 F.C. Meinzer, Functional convergence in plant responses to the environment, Oecologia 134 (2003), pp. 1-11.

Meinzer et al., 2005 F.C. Meinzer, B.J. Bond, J.M. Warren and D.R. Woodruff, Does water transport scale universally with tree size?, Funct. Ecol. 19 (2005), pp. 558-565.

Meinzer et al., 1995 F.C. Meinzer, G. Goldstein, P. Jackson, N.M. Holbrook, M.V. Gutierrez and J. Cavelier, Environmental and physiological regulation of transpiration in tropical forest gap species: the influence of boundary layer and hydraulic properties, Oecologia 101 (1995), pp. 514-522.

Moser et al., in press Moser, G., Leuschner, C., Hertel. D., Hölscher, D., Köhler, M., Leitner, D., Michalzik, B., Prihastanti, E., Tjitrosemito, S., Schwendenmann, L. Response of cocoa trees (Theobroma cacao) to a 13-month desiccation period in Sulawesi, Indonesia. Agroforest. Syst., in press.

Mualem, 1976 Y. Mualem, A new model for predicting the hydraulic conductivity of unsaturated porous media, Water Resour. Res. 12 (1976), pp. 513-522. Full Text via CrossRef | View Record in Scopus | Cited By in Scopus (1310)

Nash and Sutcliffe, 1970 J.E. Nash and J.V. Sutcliffe, River flow forecasting through conceptual models. Part I - A discussion of principles, J. Hydrol. 10 (1970), pp. 282-290.

Nepstad et al., 2002 D.C. Nepstad, P. Moutinho, M.B. Dias-Filho, E. Davidson, G. Cardinot, D. Markewitz, R. Figueiredo, N. Vianna, J. Chambers, D. Ray, J.B. Guerreiros, P. Lefebvre, L. Sternberg, M. Moreira, L. Barros, F.Y. Ishida, I. Tohlver, E. Belk, K. Kalif and K. Schwalbe, The effects of partial throughfall exclusion on canopy processes, aboveground production, and biogeochemistry of an Amazon forest, J. Geophys. Res. 107 (2002), pp. 1-18.

O’Grady et al., 1999 A.P. O'Grady, D. Eamus and L.B. Hutley, Transpiration increases during the dry season: patterns of tree water use in eucalypt open-forests of Northern Australia, Tree Physiol. 19 (1999), pp. 591-597.

Ong et al., 1999 C.K. Ong, J.D. Deans, J. Wilson, J. Mutua, A.A.H. Khan and E.M. Lawson, Exploring belowground complementarity in agroforestry using sap flow and root fractal techniques, Agroforest. Syst. 44 (1999), pp. 87-103. 
Pataki et al., 2000 D.E. Pataki, R. Oren and W.K. Smith, Sap flux of co-occurring species in a western subalpine forest during seasonal soil drought, Ecology 81 (2000), pp. 2557-2566.

Quinn et al., 1978 W.H. Quinn, D.O. Zopf, K.S. Short and R.T.W. Kuo Yang, Historical trends and statistics of the southern oscillation. El Niño and Indonesian droughts, Fish Bull. 76 (1978), pp. 663-678.

Radersma and De Ridder, 1996 S. Radersma and N. De Ridder, Computed evapotranspiration of annual and perennial crops at different temporal and spatial scales using published parameter values, Agric. Water Manag. 31 (1996), pp. 17-34.

RDCT, 2008 R Development Core Team, 2008. R: A language and environment for statistical computing. R Foundation for Statistical Computing, Vienna, Austria. ISBN 3-900051-07-0, http://www.R-project.org.

Ritter et al., 2003 A. Ritter, F. Hupet, R. Munoz-Carpena, S. Lambot and M. Vanclooster, Using inverse methods for estimating soil hydraulic properties from field data as an alternative to direct methods, Agric. Water Manag. 59 (2003), pp. 77-96.

Schaap and Leij, 2000 M.G. Schaap and F.J. Leij, Improved prediction of unsaturated hydraulic conductivity with the Mualemvan Genuchten model, Soil Sci. Soc. Am. J. 64 (2000), pp. 843-851.

Schaap et al., 2001 M.G. Schaap, F.J. Leij and M.T. van Genuchten, ROSETTA: a computer program for estimating soil hydraulic parameters with hierarchical pedotransfer functions, J. Hydrol. 251 (2001), pp. 163-176.

Schlegel et al., 2004 P. Schlegel, B. Huwe and W.G. Teixeira, Modelling species and spacing effects on root zone water dynamics using Hydrus-2D in an Amazonian agroforestry system, Agroforest. Syst. 60 (2004), pp. 277-289.

Schroth, 1999 G. Schroth, A review of belowground interactions in agroforestry, focussing on mechanisms and management options, Agroforest Syst. 43 (1999), pp. 5-34.

Schroth and Lehmann, 1995 G. Schroth and J. Lehmann, Contrasting effects of roots and mulch from three agroforestry tree species on yields of alley cropped maize, Agric. Ecosys. Environ. 54 (1995), pp. 89-101.

Schroth and Zech, 1995 G. Schroth and W. Zech, Root length dynamics in agroforestry with Gliricidia sepium as compared to sole cropping in the semi-deciduous rainforest zone of West Africa, Plant Soil 170 (1995), pp. 297-306.

Schwendenmann et al., 2010 L. Schwendenmann, E. Veldkamp, G. Moser, D. Hölscher, M. Köhler, Y. Clough, I. Anas, G. Djajakirana, S. Erasmi, D. Hertel, D. Leitner, C. Leuschner, B. Michalzik, P. Propastin, A. Tjoa, T. Tscharntke and O. van Straaten, Effects of an experimental drought on the functioning of a cacao agroforestry system, Sulawesi, Indonesia, Glob. Chang Biol. 16 (2010), pp. 1515-1530

Sheffield and Wood, 2008 J. Sheffield and E.F. Wood, Projected changes in drought occurrence under future global warming from multi-model, multi-scenario, IPCC AR4 simulations, Clim. Dyn. 31 (2008), pp. 79-105.

Šimůnek et al., 2008 J. Šimůnek, M. Šejna, H. Saito, M. Sakai and M.T. van Genuchten, The HYDRUS-1D Software Package for Simulating the One-dimensional Movement of Water, Heat, and Multiple Solutes in Variably Saturated Media, Department of Environmental Sciences, University of California Riverside, Riverside, California, USA (2008) Version 4.0.

Sommer et al., 2003 R. Sommer, H. Fölster, K. Vielhauer, E.J. Maklouf Carfvalho and P.L.G. Vlek, Deep soil water dynamics and depletion by secondary vegetation in the eastern Amazon, Soil Sci. Soc. Am. J. 67 (2003), pp. 1672-1686.

van Genuchten, 1980 M.T. van Genuchten, A closed-form equation for predicting the hydraulic conductivity of unsaturated soils, Soil Sci. Soc. Am. J. 44 (1980), pp. 892-898.

van Genuchten, 1987 van Genuchten, M.T., 1987. A numerical model for water and solute movement in and below the root zone. Res. Rep. 121, U.S. Salinity Lab., Agric. Res. Serv., U.S. Dep. of Agric., Riverside, California.

van Genuchten and Gupta, 1993 M.T. van Genuchten and S.K. Gupta, A reassessment of the crop tolerance response function, Bull. Indian Soc. Soil Sci. 4 (1993), pp. 730-737.

van Kanten and Vaast, 2006 R. van Kanten and P. Vaast, Transpiration of arabica coffee and associated shade tree species in suboptimal, low-altitude conditions of Costa Rica, Agroforest. Syst. 67 (2006), pp. 187-202. 
Veldkamp and O’Brien, 2000 E. Veldkamp and J.J. O’Brien, Calibration of a frequency domain reflectrometry sensor for humid tropical soils of volcanic origin, Soil Sci. Soc. Am. J. 64 (2000), pp. 1549-1553.

Verchot et al., 2007 L.V. Verchot, M. van Noordwijk, S. Kandji, T.P. Tomich, C.K. Ong, A. Albrecht, J. Mackensen, C. Bantilan, K.V. Anupama and C. Palm, Climate change: linking adaptation and mitigation through agroforestry, Mitig. Adapt. Strat. Glob. Change 12 (2007), pp. 901-918.

Vrugt et al., 2001 J.A. Vrugt, M.T. van Wijk, J.W. Hopmans and J. Šimůnek, One, two, and three-dimensional root water uptake functions for transient modelling, Water Resour. Res. 37 (2001), pp. 2457-2470.

Zeppel et al., 2008 M.J.B. Zeppel, C.M.O. Macinnis-Ng, C.R. Ford and D. Eamus, The response of sap flow to pulses of rain in a temperate Australian woodland, Plant Soil 305 (2008), pp. 121-130.

Zhang et al., 1999 L. Zhang, W.R. Dawes and G.R. Walker, Predicting the Effect of Vegetation Changes on Catchment Average Water Balance, Cooperative Research Centre for Catchment Hydrology, CSIRO Land and Water, Canberra, ACT, Australia (1999).

Zuidema et al., 2005 P.A. Zuidema, P.A. Leffelaar, W. Gerritsma, L. Mommer and N.P.R. Anten, A physiological production model for cocoa (Theobroma cacao): model presentation, validation and application, Agric. Syst. 84 (2005), pp. 195-225. 


\section{CHAPTER 6 \\ CONCLUSIONS}
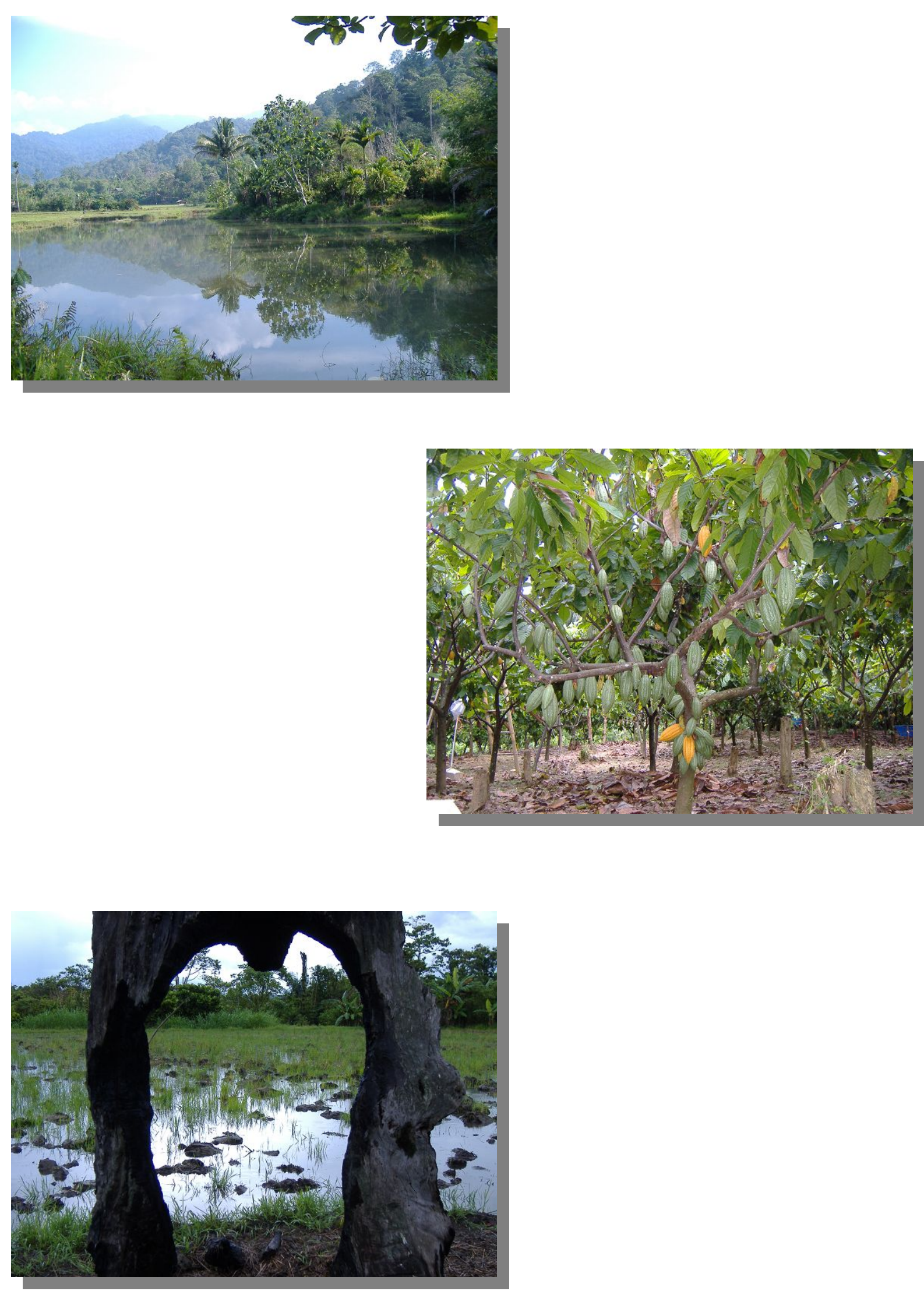
This dissertation brings together three studies which focus on the water use characteristics of tree based land use systems, and on how tree structure, environmental variables, and varying soil water content affect water use characteristics. The aim was threefold: 1) to give information on the water use characteristics of trees commonly used for reforestation and agroforestry purposes, 2) to test whether species selection might be an appropriate tool to manage water use, and 3) to examine how a specific agroforestry system responded to an artificial drought.

In the Indonesian agroforest significant differences were observed between species in both maximum sap flux density and sap flux response to environmental variables. Despite similar sap flux densities in the outer xylem, the water use rates of Gliricidia trees at a given diameter were much lower than cacao, a consequence of the shallower sap wood depth of large Gliricidia trees attributed to heartwood formation. Gliricidia shade trees were found to enhance stand water use not only due to their own water use, but also by increasing water use rates of associated cacao. Because cacao tree diameter and leaf area increased with decreasing canopy gap fraction (low gap fraction is indicative of pronounced shading), it was concluded that proximity to shade trees would enhance vegetative growth thereby enhancing water use.

From this first study it can be concluded that not only species identity, but also stand structure, shading regime, and tree exposure all have considerable effects on stand water use rates. If stand water use would be the quantity to influence by shade management, a few large Gliricidia shade trees should be desired over many smaller ones, because the number of cacao trees in direct proximity to shade trees will be reduced. A few large Gliricidia trees might also use less water than many smaller ones because the increase in water use rates with increasing tree diameter is moderate due to the shallow sap wood depth of Gliricidia. Another valuable strategy for reducing stand water use rates is the reduction of cacao leaf area by pruning because water use was found to be positively related to leaf area. More research should focus on the comparison of water use rates of cacao agroforestry systems with different shade tree densities to validate these findings and suggestions. It is also important to note that strategies aimed at reducing stand water use rates may interfere with production goals aimed at maximizing cacao yield.

A comparison of the water use characteristics of the cacao/Gliricidia agroforest with data from other tropical reforestations of similar age revealed that species choice may also exert a strong effect on stand water use. Significant differences were found in maximum sap flux density and response to environmental parameters between 17 studied species. Only a very weak relationship between maximum sap flux density and tree diameter was detected. However, in Indonesia this was mainly attributed to the different diameter range sampled for cacao and Gliricidia trees. Species water use rates differed up to twofold for a given tree diameter and no species in- 
dependent relationships between sap wood depth and tree diameter were detected in our analysis of data gathered in Indonesia, Panama, and the Philippines. This appears to contradict the hypothesis of functional convergence. However, a relatively strong dependency of tree water use on tree diameter was still found. But since tree diameter is used to calculate tree water use, there is a strong auto correlation determining the relationship. This leads to the conclusion that in young and homogeneous reforestation or agroforestry stands which have a limited diameter range, functional convergence might be less pronounced. If this is indeed the case, then species selection could be a valuable tool for balancing production goals with water use rates. Combining trees with low cumulative daily sap flux density, shallow sap wood, and a sharp decline in sap flux density with increasing sapwood depth, would therefore minimize stand water use. In this context it is pertinent to mention that certain species in Panama and the Philippines shed their leaves during the dry season, leading to a further reduction in water use on an annual scale.

But species with relatively low daily water use rates, may also exhibit certain leaf or branch characteristics that cause very high rainfall interception rates. In this case, the benefits of low transpirational water use overlap with increased evaporation of water from the canopy, which leaves less water available for root water uptake. In addition to research on species-specific water use rates under varying environmental conditions and stand structures, further throughfall measurement studies are needed (where stand structure will allow) to assess the interception characteristics of particular species. Other strategies could also be used to separate and assess the relative contribution of a species' transpiration and its impact on rainfall interception (evaporation). For example, a combination of sap flux measurements could be taken from individual trees and analyzed alongside estimates of overall stand evapotranspiration estimates which could be made using a method such as eddy covariance measurements.

The third part of this dissertation deals with the response of two tree species within a given agroforestry system to reduced throughfall, and the effects of drought on the soil water budget. The overarching conclusion drawn from this study was that reduced soil water content had little effect on tree transpiration, and that among other factors (e.g. low stand transpiration) soil water partitioning might have been a main reason for the drought resiliency exhibited. Especially remarkable was the finding that, during long periods with limited precipitation, competition between the two species for water resources was either minimal or in favor of cacao. It may seem surprising that a shallow rooted tree like cacao would cope better with reduced soil water availability than the deeper rooted Gliricidia, however, cacao could benefit from the limited amount of water entering the roof and partially rewetting the topsoil; whereas this water source was hardly available to the deeper roots of the Gliricidia. In addition, maximum rock fragment content was 
found in soil layers where maximum Gliricidia rooting density was found, further decreasing the water availability for this species. Stable isotope data collected during the time of roof closure are now being processed (L. Schwendenmann) and might also help to clarify which role soil water partitioning played in the stand. Furthermore, Gliricidia seemed to lack the active osmotic adjustment of the roots that was seen in cacao.

The soil water budget indicated that throughfall exceeded evapotranspiration during most months of the experiment. Nonetheless, significant declines in soil moisture storage were detected, indicating that drainage was one of the largest drivers of the decline in soil water content. The sap flux for both tree species in the roof plots only exhibited levels comparable to the control when drainage rates were high in the roof plots (beginning of the experiment) or when soil moisture storage recovered at the end of the experiment. This indicates that high tree transpiration was dependent on a certain quantity of available "surplus water" which might be indicative of very high soil water potentials.

One limitation of this study however was that soil water potential could not be monitored alongside soil water content at a series of depths. Therefore, no tree specific root water uptake parameters can be ascertained from this study so far, and the severity of the drought cannot be ultimately judged on the basis of soil water status. But a further step towards the quantification of root water uptake parameters could be to try to combine the measured stand transpiration of control plots (as input potential transpiration) with data of throughfall and soil water content from roof plots and inversely adjust the plant water uptake stress response function such that the derived actual transpiration and the measured transpiration in roof plots match. Still, modeled soil water potentials need to be verified in the field to complete this task and a breakdown to the species level is only possible by reprogramming the model to allow for two root systems. Also certainly more research on the response of cacao agroforests with different shade tree densities to throughfall reduction is needed to precisely quantify the role of shade trees on stand transpiration and stand drought response. It would be especially useful to conduct a similar experiment on the same site after the complete removal of shade trees.

In summary it can be concluded from the throughfall reduction experiment, that the combination of cacao and Gliricidia under the given soil and environmental conditions was appropriate to withstand long lasting droughts similar to those which might occur in the area during strong El Niño events. Nevertheless, the yield declines observed following the throughfall reduction experiment suggest that the income of Indonesian farmers in cacao agroforestry would still be heavily affected by droughts. 


\section{ACKNOWLEDGMENTS}

It would not have been possible to complete this dissertation without the support of all the great people around me:

I am very thankful to Prof. Dr. Dirk Hölscher for his guidance, advice, and patience. Only with Dirk's support in all fields was I able to both take care of my family and finish my PHD thesis in time.

I would also like to thank Luitgard Schwendenmann for her valuable ideas, the good discussions, the quick reading of my thesis and most importantly for all the great motivation boosts. I hope you'll do well in New Zealand.

Thanks also to Eva Siegelkow for organizing all the administrative stuff and reminding everybody of everybody's birthdays - I'll buy flowers next time, I promise!

My special acknowledgement goes to the friendly and competent support of all colleges at the Institute, in particular Diego Dierick, who supported me during my parental leave. Thanks also for sharing laughter, frustration, food and cigarettes with me.

Terima kasih banyak juga untuk orang2 yang bekerja di plot2 di Marena dan Pono, sopir2, rekan2 dan teman2 yang lain. Cuma anda sekalian bikin Indonesia tempat yang baik untuk saya! Saya mau berterima kasih untuk menjelaskan dan memperkenalkan budaya Indonesia dan untuk kesabaran dengan ini "Peneliti gila". Saya pasti akan rindu sama kalian. Terima kasih terlebih-lebih sama Bapak Masrillihardi Potabuga dan Bapak Andi Sofyan yang membantu dan menunjang saya "supaia penelitian mau jadi suksess". Semoga sehat selalu!

Thanks also to all my "orang barat" colleagues working in the STORMA project, especially Oliver, Bernhard, Carsten and Norbert who made my days at times. The time in Indonesia would not have been that great if you hadn't been there!

I am also very thankful to Sara who did a wonderful job correcting my "genglish" at times and Heidi for upgrading the punctuation in the German Introduction and supporting my well-being in Göttingen with the wonderful "Ostpaket".

My particular gratitude goes also to the grandmothers and grandfathers, aunts and uncles for all their support during the last 3 years. Lenka must have been a much unexpected surprise for all of you but nevertheless you provided a very warm welcome for each of us.

Last but not least I want to thank you, my two girls Lenka and Xenia for all the love, care and patience. The two of you managed to direct my life onto the right track. 


\section{DECLARATION OF HONOR}

I hereby declare that I am the sole author of this dissertation entitled "CACAO AGROFORESTRY UNDER AMBIENT AND REDUCED THROUGHFALL: TREE WATER USE CHARACTERISTICS AND STAND WATER BUDGETING" and that all references and data sources used have been acknowledged as such. I further declare that this work has never been submitted in any form as part of other dissertation procedures.

Göttingen, February 2010

(Michael Köhler) 


\section{Curriculum VitaE}

Name:

Date of birth:

Place of birth:

\section{Positions}

08. $2006-02.2010$

08. $2008-03.2009$

$01.2006-06.2006$

\section{Education}

08. $2006-05.2010$

08. 2005 - 06. 2006

10. $2000-04.2005$

09. $1991-06.1999$
Michael Köhler

16.11.1980

Schmölln, Germany

Research associate at Georg-August-Universität, Göttingen, Department of Tropical Silviculture and Forest Ecology

Parental leave

Research associate at Utah-State-University, Logan, Utah, Department of Biological and Irrigation Engineering

PhD programme Forest Sciences and Wood Ecology, Georg-AugustUniversität, Göttingen, Department of Tropical Silviculture and Forest Ecology

Graduate Student (DAAD Scholarship), Utah-State-University, Logan, Utah, Department of Biological and Irrigation Engineering

Diploma (MSc) in Agronomy, Martin-Luther-Universität Halle-Wittenberg, Landwirtschaftliche Fakultät

Secondary school, Schmölln

\section{List of Publications}

Hölscher, D., Faust, H., Juhrbandt, J., Moser, G., Binternagel, N., Köhler, M., van Edig, X., Schwarze, S., Schwendenmann, L., Barkmann, J., Veldkamp, E., Cacao agroforestry under drought risk - an ecological and socio-economic analysis. Forests, Trees and Livelihoods (in review).

Schwendenmann, L., Dierick, D., Köhler, M., Hölscher, D., Can deuterium tracing be used for reliably estimating water use of tropical trees and bamboo? Tree Physiology (in press).

Köhler, M., Schwendenmann, L., Hölscher, D., Throughfall reduction in a cacao agroforest: tree water use and soil water budgeting. Agricultural and Forest Meteorology (in press).

van Straaten, O., Veldkamp, E., Köhler, M., Anas, I., 2010. Spatial and temporal effects of drought on soil $\mathrm{CO}_{2}$ efflux in a cacao agroforestry system in Sulawesi, Indonesia. Biogeosciences 7, 1223-1235.

Moser, G., Leuschner, C., Hertel, D., Hölscher, D., Köhler, M., Leitner, D., Michalzik, B., Prihastanti, E., Tjitrosemito, S., Schwendenmann, L., 2010. Response of cocoa trees (Theobroma cacao) to a 13-month desiccation period in Sulawesi, Indonesia. Agroforestry Systems 79, 171-187.

Schwendenmann, L., Veldkamp, E., Moser, G., Hölscher, D., Köhler, M., Clough,Y., Anas, I., Djajakirana, G., Erasmi, S., Hertel, D., Leitner, D., Leuschner, C., Michalzik, B., Propastin, P., Tjoa, A., Tscharntke, T., van Straaten, O., 2010. Effects of an experimental drought on the functioning of a cacao agroforestry system, Sulawesi, Indonesia. Global Change Biology 16, 1515-1530.

Dierick, D., Kunert, N., Köhler, M., Schwendenmann, L., Hölscher, D., 2010. Comparison of tree water use characteristics in reforestation and agroforestry stands across the tropics. In: T. Tscharntke, C. Leuschner, E. Veldkamp, H. Faust, E. Guhardja, A. Bidin (Eds.), Tropical Rainforests and Agroforests under Global Change, Springer, Berlin, pp 293-308.

Köhler, M., Dierick, D., Schwendenmann, L., Hölscher, D., 2009. Water use characteristics of cacao and Gliricidia trees in an agroforest in Central Sulawesi, Indonesia. Ecohydrology 2, 520-529. 
